Portland State University

PDXScholar

\title{
Attitudes, Behavior, and Archetypes in the Clackamas River Basin: a Model of Water Customer Analysis and Outreach for Watershed Protection and Conservation
}

Daniel Close Larson

Portland State University

Follow this and additional works at: https://pdxscholar.library.pdx.edu/open_access_etds

Part of the Water Resource Management Commons

Let us know how access to this document benefits you.

\section{Recommended Citation}

Larson, Daniel Close, "Attitudes, Behavior, and Archetypes in the Clackamas River Basin: a Model of Water Customer Analysis and Outreach for Watershed Protection and Conservation" (2019). Dissertations and Theses. Paper 5498.

https://doi.org/10.15760/etd.7371

This Dissertation is brought to you for free and open access. It has been accepted for inclusion in Dissertations and Theses by an authorized administrator of PDXScholar. Please contact us if we can make this document more accessible: pdxscholar@pdx.edu. 
Attitudes, Behavior, and Archetypes in the Clackamas River Basin: A Model of Water Customer Analysis and Outreach for Watershed Protection and Conservation

by

Daniel Close Larson

A dissertation submitted in partial fulfillment of the

requirements for the degree of

Doctor of Philosophy

in

Earth, Environment and Society

Dissertation Committee:

Heejun Chang, Chair

Max Nielsen-Pincus

Joel S. Steele

Julius McGee

Portland State University 2019 
(C) 2019 Daniel Close Larson 


\begin{abstract}
Fresh water resources around the globe are under threat of diminishing supply and quality due to rapid population growth, climate change, drought, and waste. This dissertation aims to address the protection of fresh water at the source, the tap, and how water customer attitudes influence protection and conservation using a watershed-wide lens. Using the Clackamas River Watershed which resides within the Portland Metropolitan Area (PMA), I seek to investigate water customer attitudes towards a source water protection program and their willingness to pay to support such an endeavor, attitudes and behaviors that result in household water conservation, and an exploration of the attitudes and spatial distribution of unique distinct groups of water customer, referred to as customer types. I address the interplay of attitudes, behavior, and conservation through social surveys, statistical analysis, and spatial analysis. I demonstrate that certain attitudes towards climate and water conservation are significant predictors of support for source watershed protection and increased household water conservation. These attitudes are also primary drivers of the segmentation of water customers into unique types. This dissertation provides a valuable two-fold lesson serving as a catalyst for watershed protection and water conservation programs by providing the knowledge base for initiating outreach and social engagement campaigns. In addition, this work provides a model for attitudinal and behavioral exploration of a population that should be applied and tested in other geographic contexts. Further increasing our understanding of critical precursors necessary to initiate protection and conservation programs is a step towards promoting the resilience and sustainability of our precious fresh water systems.
\end{abstract}




\section{Acknowledgements}

I would like to express my sincere gratitude to my committee for their help, guidance, and contributions during my $\mathrm{PhD}$ process. To Heejun Chang, my primary advisor who labored tirelessly in providing direction, insight, and keeping me accountable. He encouraged me to explore my varied interests, while keeping me focused on the end results and adhering to my goals. To Max Nielsen-Pincus, your help, advice, and time during the research gathering, analysis, and writing phases of my research experience were critically important. To Joel Steele, for graciously volunteering his time during "down and dirty" analysis and interpretation sessions while providing keen mentorship. To Julius McGee, many thanks for serving as my graduate representative and providing insightful comments that pushed me to think beyond my disciplinary lens.

To all of my IGERT family, thank you all for your help and for fostering a warm community, while providing a "safe space" for much needed commiseration that is integral to the doctoral journey. To Darrell Brown, for serving as an excellent PI for the IGERT program while maintaining a cool "Mountain West" sense of humor. Your mentorship and advice are truly appreciated. To all of the IGERT faculty, thank you for creating such a wonderful program and engendering a positive environment for intellectual discourse. To all of other PSU friends and colleagues, thank you for enriching my experience with thoughtful discussions and witty banter.

To my family and friends, thank you all for your support and devotion during my journey. Your encouragement kept me going. Having a sense of community during the trials and tribulations of graduate school was a true blessing. Most importantly to my wife Lauren and our adorable cat Lexi, your unyielding support, love, and adoration is ultimately what made this experience possible. 
Thank you for listening to me ramble about my research and feigning interest when needed. I can't wait for the next chapter in our lives. The saga continues... 


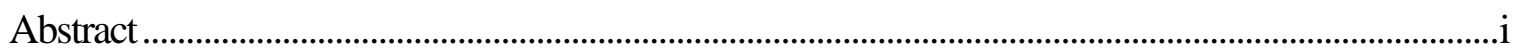

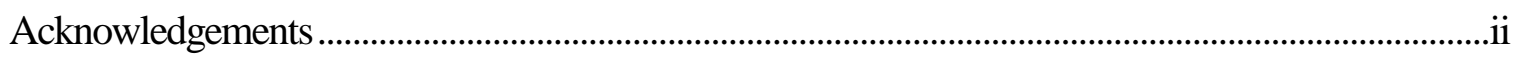

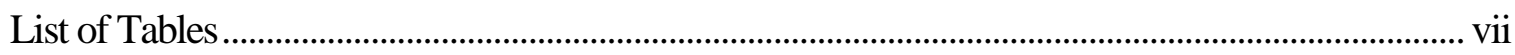

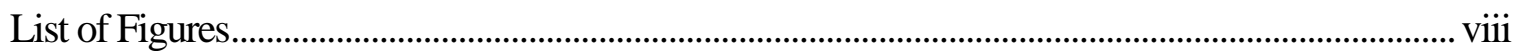

Chapter 1: Willingness to Pay for Source Water Protection: A Case-Study of Water Customer Attitudes in the Clackamas River Basin, Oregon, USA...................................................................

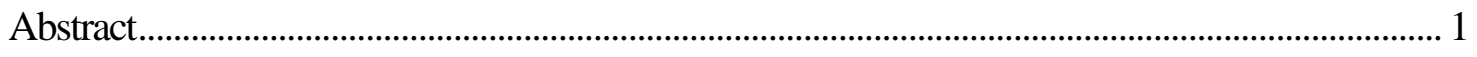

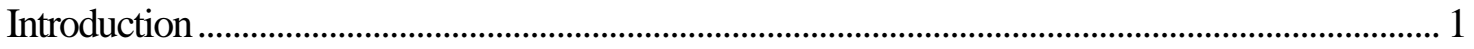

Purpose and Research Questions ................................................................................................... 8

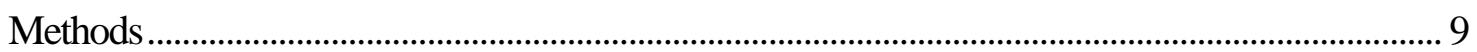

Study Area and Context .................................................................................................. 9

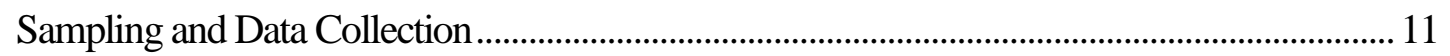

Survey questions and coding survey responses ....................................................................... 13

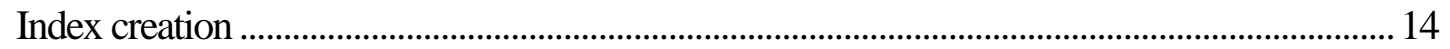

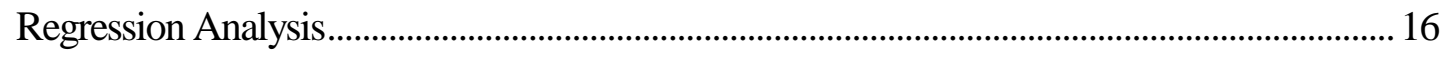

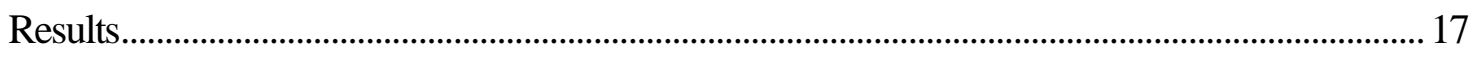

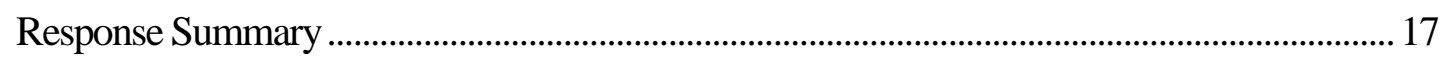

Influence of Bid Levels and Intervention Scenarios on Willingness to Pay............................... 20

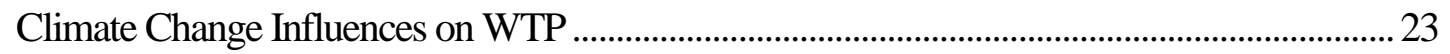

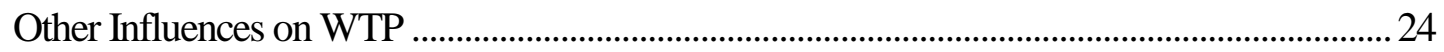

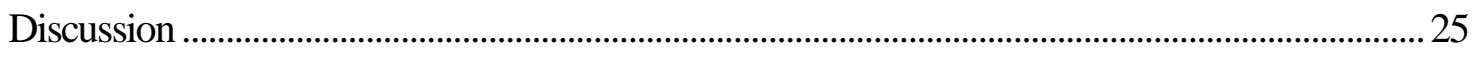

Opportunities for theoretical SWPP Program Design................................................................ 27

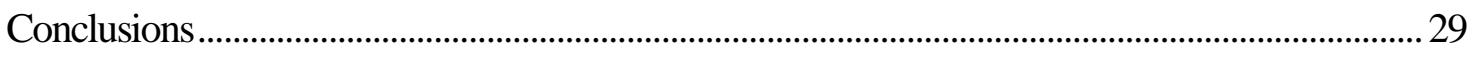

Chapter 2: Water Conservation Attitudes and Behavior: A Path-Analysis.......................................... 32

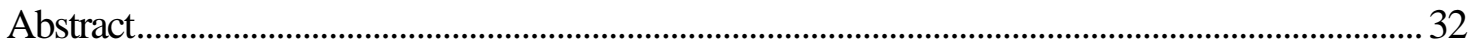

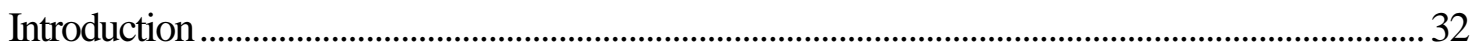

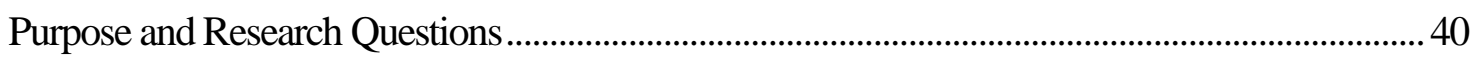

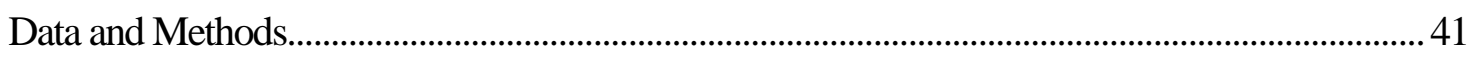

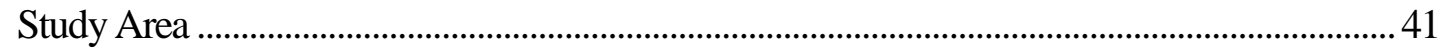

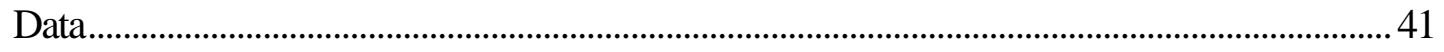


Variables 43

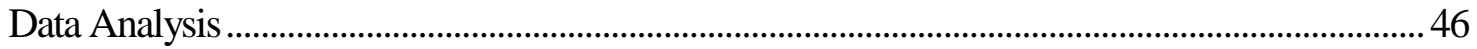

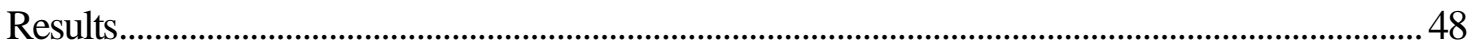

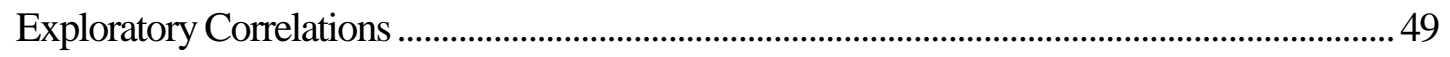

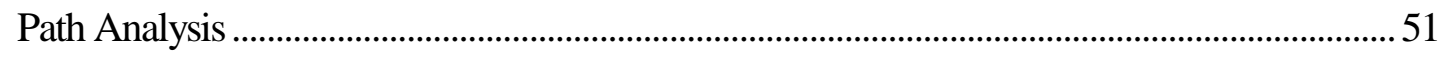

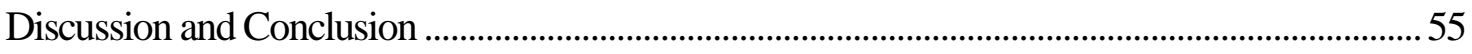

Chapter 3: Clackamas Water Customer Types: What are they and what is their distribution? ........ 60

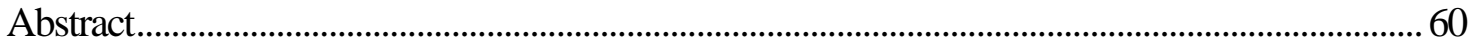

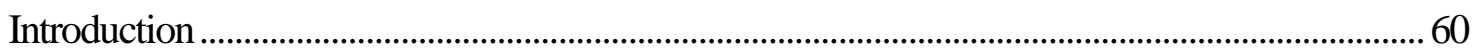

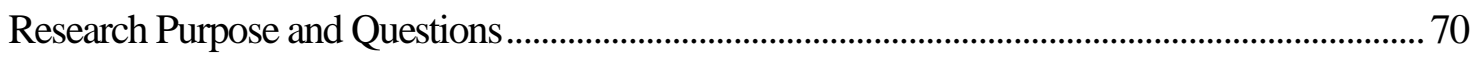

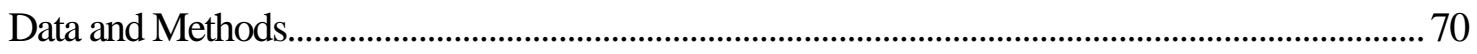

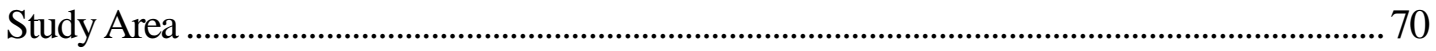

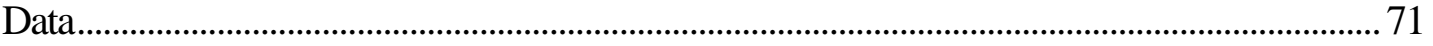

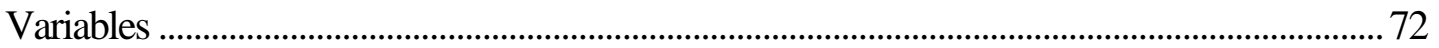

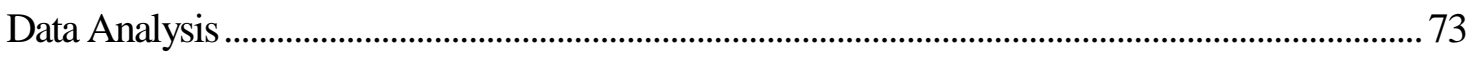

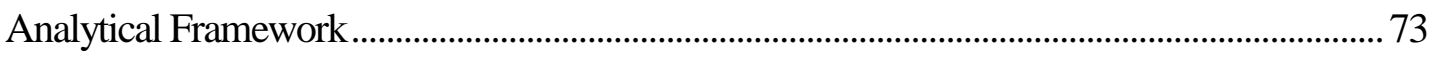

Univariate Summary ............................................................................................................ 74

Exploratory Correlations ................................................................................................................. 74

Water Customer Types - Hierarchical Cluster Analysis............................................................. 75

Spatial Distribution of Water Customer Types.......................................................................... 76

Factors determining spatial variation of customer types - Geographically Weighted Regression

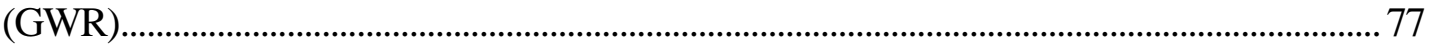

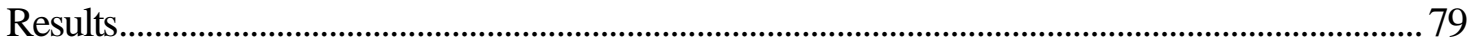

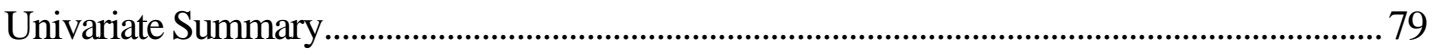

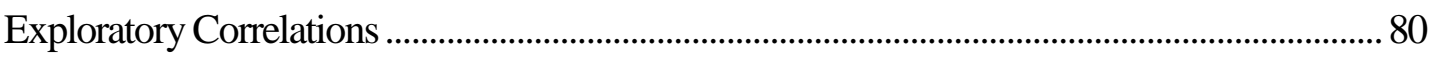

Water Customer Segments ................................................................................................. 83

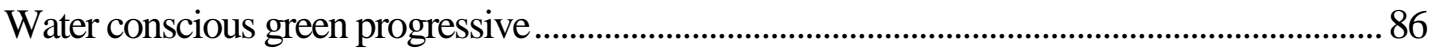

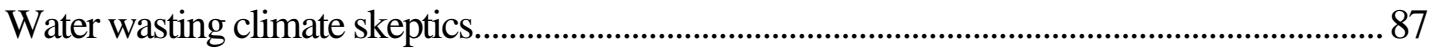

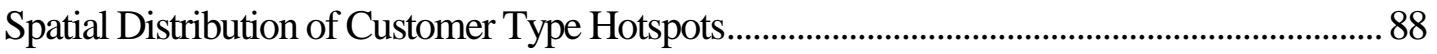

Factors determining spatial variation of customer types - OLS Regression ...............................90

Geographically Weighted Regression ........................................................................................... 91 


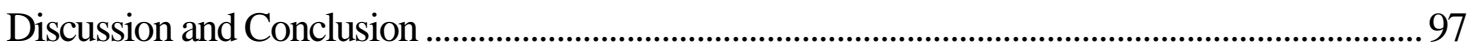

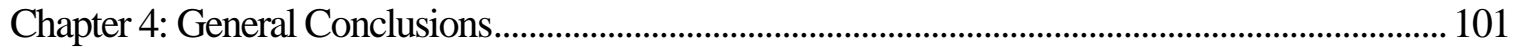

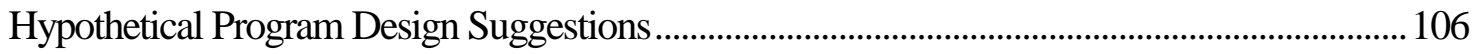

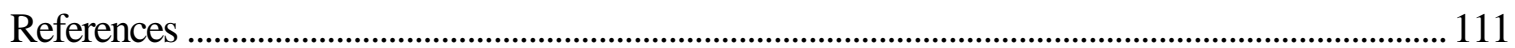

Appendix A: Factor Loading for Exploratory Factor Analysis (EFA) Derived Variables............... 122

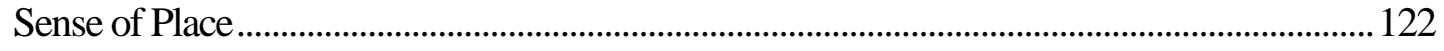

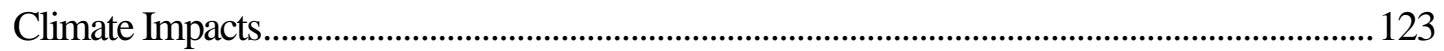

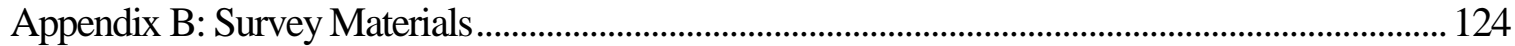

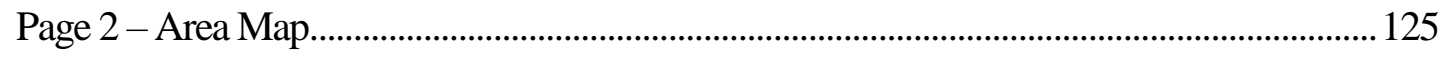

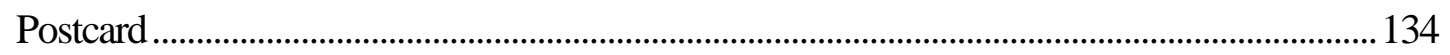




\section{List of Tables}

Table 1-1. Data and Measures

Table 1-2. Clackamas River drinking water ratepayer respondent characteristics summarized by category. Non-responses were omitted from calculation.

Table 1-3. Logit Regression Modeling results and predicted probabilities of willingness to pay on monthly water utility bills for source water protection in the Clackamas River watershed $(n=447)$.

Table 1-4. Marginal Effects at Representative Values (MEARV) for \$1 \& \$5 Bid Amounts and Scenarios 22

Table 2-1. Current Literature Pertaining to Water Conservation

Table 2-2. Variables collected by survey $(n=405)$.

Table 2-3. Descriptive statistics of analysis variables

Table 2-4. Attitudes - Behavior - Water Savings Path Analysis Model Fit Indices

Table 3-1. Current Literature pertaining to Social Marketing and Audience Segmentation............. 64

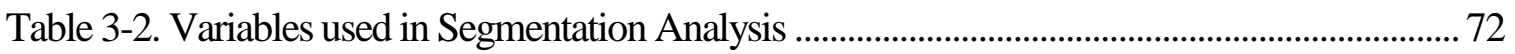

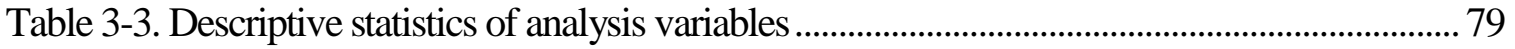

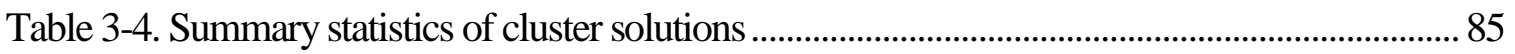

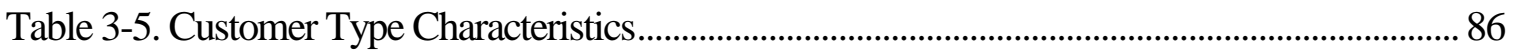

Table 3-6. OLS regression model results for Water Conservation and Climate Attitudes by customer type

Table 3-7. GWR regression model results for Water Conservation and Climate Attitudes by customer type

Table 5-1. Factor Loadings and Communality Estimates for Sense of Place Variables.

Table 5-2. Factor Loadings and Communality Estimates for Climate Impact Attitudes 


\section{List of Figures}

Figure 1-1. Study Area and Water Service Providers....................................................................... 11

Figure 1-2. Probability of Participation Willingness of increasing bid levels on Private Land......... 23 Figure 1-3. Probability of Participation Willingness based on strength of Climate Impact Attitudes.

Figure 2-1. Average Household Water Consumption in three water districts of the Clackamas River

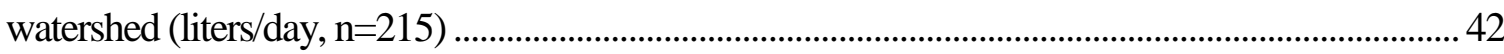

Figure 2-2. Correlation Matrix of Analysis Variables ……………………………………………...5 50

Figure 2-3. Path model depicting variables and standardized coefficients ( $\beta$ )...................................55

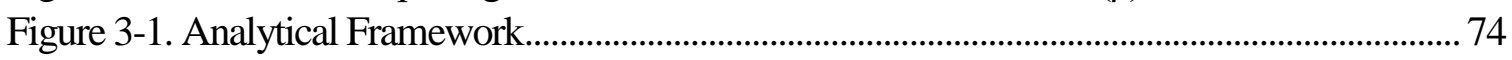

Figure 3-2. Exploratory Correlations of Analysis Variables.................................................................. 82

Figure 3-3. Water Customer Dendrogram ....................................................................................... 83

Figure 3-4. Plot of Cluster Solutions................................................................................................. 84

Figure 3-5. Water customer typology ……………………………………………………….... 85

Figure 3-6. Getis-Ord Gi* Optimized Hot Spot Analysis of Customer Types..................................... 89

Figure 3-7. GWR coefficients for Political Attitudes and Age ............................................................ 94

Figure 3-8. GWR coefficients for Political Attitudes...................................................................... 96

Figure 4-1. Water conservation normative messaging placard utilized by Sacramento, CA.......... 109 
Chapter 1: Willingness to Pay for Source Water Protection: A Case-Study of Water Customer Attitudes in the Clackamas River Basin, Oregon, USA.

\begin{abstract}
A hedge against risks to water systems gaining in popularity are Payment for Watershed Services (PWS) programs. Previous studies have explored the notion of willingness to pay (WTP) for climate risk mitigation measures, yet the body of this research is at national or global scales. We evaluated the potential for a PWS program in the Clackamas River Basin in the Portland, OR Metropolitan area (PMA) in the western United States using Clackamas Watershed residents' survey. We distributed 1,200 surveys in a stratified random sample with a 34\% response rate resulting in $(n=406)$ valid responses. Respondents' perceptions of Pacific Northwest climate degradation and frequent use of the watershed were significant predictors of WTP for a program designed to improve and protect drinking water quality. These results provide direction for water managers on critical topics to their customers suggesting that they may frame outreach messaging for source water protection around climate change mitigation and promoting a stronger sense of place by encouraging recreation and other use activities in the watershed.
\end{abstract}

Keywords: contingent valuation; climate change; payment for ecosystem services; risk perceptions; watershed services; WTP.

\title{
Introduction
}

Within the last fifty years, the global population has made a massive relocation to cities. This massive growth coupled with the disrupting effects of climate change on water supply and sanitation systems places water resources in a precarious position (Larson et al., 2013; Bennett \& Ruef, 2016). Climate Change will affect the global hydrologic cycle and likely increase the average 
global temperature and alter precipitation regimes. The World Health Organization and the UN postulate that 800 million people globally do not have access to freshwater and by 2025, 2 billion people live in regions facing severe water scarcity (Gartner, Todd, Kara Di Francesco, Suzanne Ozment, Heidi Huber-Stearns, Nathaniel Lichten, 2016). Innovative policies and projects are gaining momentum worldwide to rectify the need for access to fresh water.

This introductory section of this paper will provide a conceptual overview of the theory and topics relevant to our research: 1) Review of the Values, Beliefs, Norms (VBN) Theory and how it influences pro-environmental behavior; 2) Payment for Ecosystem Services (PES) programs and how they are structured; 3) The purpose and need for Source Water Protection Programs (SWPP); 4) Methods for assessing nonmarket environmental value; 5) Climate change and support for watershed protection; 6) Assessing support for SWPP.

\section{VBN Theory}

The theory guiding this proposed research is the Values, Beliefs, Norms (VBN) Theory of environmental concern and behavior (Dietz, Dan, \& Shwom, 2007). VBN identifies possible indirect links between values and environmental behaviors. The norm-activation theory forwarded by Schwartz (2017) has been applied to numerous studies of environmental behaviors. Behaviors result from beliefs about the consequences of actions and attitudes towards personal responsibility for undertaking such action. When individuals acknowledge that environmental conditions pose threats to others or the environment they are more likely to choose pro-environmental behaviors (Dietz et al., 2007). Schwartz (2017) defines a "personal norm for action" as a condition when individuals acknowledge their actions could prevent or mitigate adverse environmental impacts, they are more likely to act. 
Payments for Ecosystem Services (PES)

Payments for Ecosystem Services (PES) programs, are an increasingly popular policy mechanism enabling the use of market-based instruments for the conservation of valuable ecosystem services (Gómez-Baggethun et al., 2010). PES programs provide financial incentives to land owners or resource managers for implementing conservation actions that supply ecosystem services to beneficiary communities. A global assessment of water markets and various PES mechanisms found that the majority of local water user-driven watershed investments involved communities and businesses leveraging public financing instruments for watershed protection. In partnerships between communities and businesses, management decisions are made locally, but funding is made readily available from higher levels of government. Partnership watershed protection models have been demonstrated to be a more sustainable long term approach towards source water protection (Bennett \& Ruef, 2016). Local water-user driven water investment is characterized as Payment for Watershed Services (PWS)(Bennett, Gosnell, Lurie, \& Duncan, 2014a), a specific type of PES scheme that compensates land owners for watershed protection. These actions are intended to result in increased water supply, reduced pollutant loading, and flood mitigation however empirical observations of PWS outcomes and program effectiveness are lacking in the literature. ((Asbjornsen et al., 2015; Brouwer, Tesfaye, \& Pauw, 2011; Grima, Singh, Smetschka, \& Ringhofer, 2016)).

Within the last decade water service providers have awakened to the importance of healthy ecosystems and the vital ecosystem services they provide in terms of fresh water. In 2015, \$25 Billion was spent on green infrastructure for water, with transactions increasing $12 \%$ /year between 2013 and 2015 (G. Bennett \& Ruef, 2016). There are a total of 419 documented programs in 62 
countries invested in green infrastructure for water (G. Bennett \& Ruef, 2016). The goal of these programs is the provision of freshwater from ecosystems to ensure reliable clean water supplies, and offsetting the effects of climate change, rapid urban expansion, and pollution (G. Bennett \& Ruef, 2016).

PWS programs are particularly relevant within the United States given that much of the existing built infrastructure in the United States is reaching the end of its design life and due for an upgrade. Replacement of this existing infrastructure could cost more than $\$ 1$ trillion over the next 25 years (Drinking Water Infrastructure Report Card, n.d.). Given these facts, water managers and communities within the U.S. are looking towards alternative and holistic approaches to remedy this issue (Gartner et al., 2017). Water managers have an inherent motivation to hedge against the waterrelated risks due to climate change, and water customers have a perennial need for high quality fresh water. We seek to demonstrate that water customers' perceived risks to water resources due to climate change may serve as a useful tool for water managers and policy makers in framing messages to water customers around the necessity and benefits of watershed protection.

\section{Source Water Protection Programs (SWPP)}

Source Watershed Protection Programs (SWPP) are a designed to ensure the continued provision of high-quality drinking water. However, such programs often lack direct and effective mechanisms for protecting water quality (Bennett et al. 2014b). One emerging approach for improving water quality applies water utility fees to enhance areas in the watershed that are important to maintaining water quality and supply. The success of such mechanisms relies partly on the willingness of utility ratepayers to reduce risks to water supplies by investing in watershed protection (Lurie et al., 2013a). Previous work has shown that ratepayer's willingness to pay 
(WTP) is influenced by such factors as income and resource use (Flores and Carson 1997); political ideology (Dupont and Bateman 2012); cultural perspectives (Daniel et al. 2012); and sense of place (Nielsen-Pincus, Sussman, Bennett, Gosnell, \& Parker, 2017).

\section{Methods for Assessing Nonmarket Environmental Value}

Contingent Valuation (CV) is a method in economics commonly used for valuing nonmarket environmental resources by determining a person's willingness to pay (WTP) to protect a particular water body or forest as these resources provide some ancillary benefit such as water quality (Kramer \& Mercer, 2019). There is a body of research that investigates climate risk perceptions on WTP (Akter \& Bennett, 2011; Manne \& Richels, 2005; Pindyck, 2012). However, the bulk of this research focuses on global or national climate phenomena such as carbon emissions, and not place-based regional water resources. Other studies have demonstrated the linkage between WTP for reduction in risk to water resources. A study conducted in Switzerland sought to elicit the WTP to reduce ecological health risks from sewer overflows as a result of increased precipitation and flooding. Results demonstrated that $71 \%$ of respondents were WTP to reduce the risk of wastewater flowing into freshwater systems and that climate change risks perceptions had a significant effect on WTP to reduce these risks. Results support previous findings of high WTP to reduce ecological and health risks (Willis et al. 2005; Martin-Ortega et al. 2011; Veronesi, Chawla, Maurer, \& Lienert, 2013). Similarly, a study in Loch Leven, Scotland conducted a WTP analysis for reductions in health risks posed by toxic algal blooms. Results reveal that $55 \%$ of respondents were WTP for reductions of toxic algal blooms. WTP for health risk reduction is dependent on respondents' perception of and attitude towards risk. People that perceive a greater health risk are WTP UK£7.91-9.55/household/year more for risk reduction (Hunter et al., 2012). Within the 
context of SWPP, a study conducted in the state of Oregon within the western U.S. found that more than half of respondents in their study $(n=406)$ were WTP $\$ 0.50$ for water quality improvements in their source watershed (Lurie et al., 2013b).

\section{Climate and Support for Watershed Protection}

The connection between climate-induced drought and public risk perceptions provides some illuminating examples that support the notion that water customers are inclined to support watershed protection as a drought mitigation strategy. Researchers in Andalusia, Spain found that drought and its connection to climate change has a direct impact on public concern for the quantity and quality of water at regional and local scales. This confirms that regional drought has direct bearing on water related perceptions, and at that scale is a key variable in the evolution of environmental concern (Paneque, Lafuente, \& Vargas, 2018). Another study in Seville, Spain found that pro-environmental attitudes were the primary motivator for supporting climate adaptation policies. Results from the studies conducted in Spain demonstrate that societal environmental commitment can be fostered by environmental information and education policies (García de Jalón, Iglesias, Quiroga, \& Bardají, 2013). Public response to information campaigns and news media coverage on climate-induced drought can produce a significant reduction in household water consumption. Researchers found that anomalously high drought media coverage was correlated to reductions in urban water use in the San Francisco Bay Area, United States from 2005-2015. These results indicate that the public will respond to informational campaigns (Quesnel \& Ajami, 2017). 
One study investigated how site-specific factors, such as drought impacts, place attachment, beliefs in climate change, influenced concern for local drought impacted resources, and conservation attitudes on lake recreationists in South Carolina, US. Researchers found that without the concern for local impacts, the influence of place attachment, local-level awareness, and climate change beliefs on site-specific pro- environmental attitudes may be limited. Coupling the influence of climate risk perceptions and WTP will be a novel contribution to the PWS literature (Brownlee, Hallo, Moore, Powell, \& Wright, 2014).

Climate change itself is not experiential, but its impacts are. Previous research on the role of direct experience and climate change risk perceptions in the U.K. found that no significant relationship existed between individuals who experienced flooding and those who did not regarding the perceived risks and outcomes of climate change. Interestingly, individuals that experienced adverse health effects from air pollution are more likely to perceive climate change as a major risk (Whitmarsh, 2008).

In order to implement a PWS program, water managers and stakeholders must have a keen understanding of their watershed service providers and customers, and the enabling conditions necessary to institute such a program. Some approaches to addressing this involve conducting an analysis of the economic viability of such a program, and the willingness of water users to support it. There are multiple methods for defining WTP. Opportunity cost analysis has been employed in East Africa to evaluate the economic gains/losses farmers would receive by participating in a watershed protection program (Atisa, Bhat, \& McClain, 2014). One novel study conducted a field experiment in which researchers created an experimental auction for water quality protection in an attempt to calculate supply and demand curves for price equilibrium as a means to provide a proof- 
of-concept for initiating local markets for watershed protection (Uchida et al., 2018). A more common approach found in the literature, is a contingent valuation of water user willingness to pay for watershed protection and the motivating factors behind their support. These factors such as sense of place, climate change impact beliefs, income, education, political attitudes, trust, and watershed use frequency provide a wealth of information to water managers and stakeholders about the beneficiaries of a PWS program. Some common factors affecting water user WTP were education level, land size, awareness of environmental degradation, sense of place, and trust (Lalika, Meire, Ngaga, \& Sanga, 2017; Lurie et al., 2013b; Nielsen-Pincus et al., 2017; Obeng \& Aguilar, 2018).

\section{Purpose and Research Questions}

The key to protecting vital water resources is developing robust and resilient watershed management plans that include novel approaches such as SWPP. An understanding of the linkages among place attitudes, demographics, and climate risk perceptions and how they influence WTP for different intervention scenarios is an important step forward in advancing a SWPP where water managers are considering adding a small fee for watershed protection activities. This information will be useful to policy-makers in how they target outreach campaigns and design informational materials for their customers. We seek to answer the following research questions.

1) Do strong place attitudes and beliefs about the impacts of climate change influence a water customers' willingness to pay for source water protection?

2) Do water customer preferences vary between different types of SWPP interventions? 
The objectives of this research are to characterize the importance of climate change impact beliefs and place attitudes, while controlling for demographics and political ideology, in determining the WTP for source water protection. The novel contribution to this work will be the incorporation of climate change risks perceptions and how that covaries with WTP. The outcomes of this analysis will be useful in identifying the most important factors that influence water customer WTP to support source water protection.

\section{Methods}

Study Area and Context

The Clackamas River Watershed lies within Clackamas County in northwestern Oregon serves as our study area. The watershed can roughly be divided in half, with the upper watershed flowing through forested areas over rugged terrain, in the lower portion of the watershed the river flows through agricultural, industrial, non-industrial private forestlands, and densely populated areas. Land ownership in the watershed is a complex tapestry of private (25\%), public (72\%), and tribal (3\%) land (Clackamas River Water Providers, 2016). The Clackamas provides important habitat area to protected anadromous fish species such as Steelhead, Chinook Salmon, and Pacific Lamprey. The watershed is an important infrastructural and economic anchor for the region with five hydroelectric projects along the river and host to many productive farms and nurseries, and ample outdoor recreational opportunities. Most importantly, the Clackamas River Watershed is a major source of drinking water for over 300,000 residents in the Greater Portland Metropolitan Area (PMA) (Clackamas River Water Providers, 2016). The PMA faces one of the highest urban growth rates in the nation at $1.77 \%$ per year (Metro, 2017). Rapid urbanization coupled with anthropogenic induced climate change are likely to jeopardize the supply and quality of water in the 
region (Graves and Chang 2007; Jung, Moradkhani, and Chang 2012). Clackamas county faces an annual growth rate of $1.1 \%$. Population growth is due largely to in-migration from outlying counties with the expectation of 107,000 new residents within the county by 2035 . This growth pressure has caused the county to designate 13,750 acres of rural land for residential development (Chun, Rancik, Haggerty, \& Ollinger, 2018). The primary surface water withdrawal in the watershed is for irrigation (44.62 Million gallons/day), the second largest use is for household consumption (27.9 Million gallons/day) (Cheryl Dieter, Molly A. Maupin, Rodney R. Caldwell, Melissa A. Harris, Tamara I. Ivahnenko, John K. Lovelace, Nancy L. Barber, 2015). This trend of rapid population growth is likely to increase surface water withdrawal in the coming years prompting the need for source water protection.

Each of the water providers using Clackamas River water collaborated to forge an intergovernmental agreement to create Clackamas River Water Providers (CRWP), an organization designed to collectively manage source water quality. This organization is comprised of representatives from the City of Estacada, the City of Lake Oswego, City of Tigard, Clackamas River Water, the North Clackamas County Water Commission (City of Gladstone and Oak Lodge Water Services), South Fork Water Board (Oregon City and West Linn), and Sunrise Water Authority (Happy Valley and Damascus) (Figure 1-1).

In its 2010 Drinking Water Protection Plan, CRWP identified two primary goals to establish a SWPP to maintain the Clackamas River as a high-quality drinking water source: 1) Identify, prevent, and mitigate potentially harmful impacts on drinking water quality; and 2) Promote awareness and stewardship of a healthy watershed through community partnerships. Source water protection strategies may range from public communication campaigns designed to 
raise awareness about drinking water source management to partnerships with watershed landowners or users designed to reduce risks to water quality (Clackamas River Water Providers, 2016).

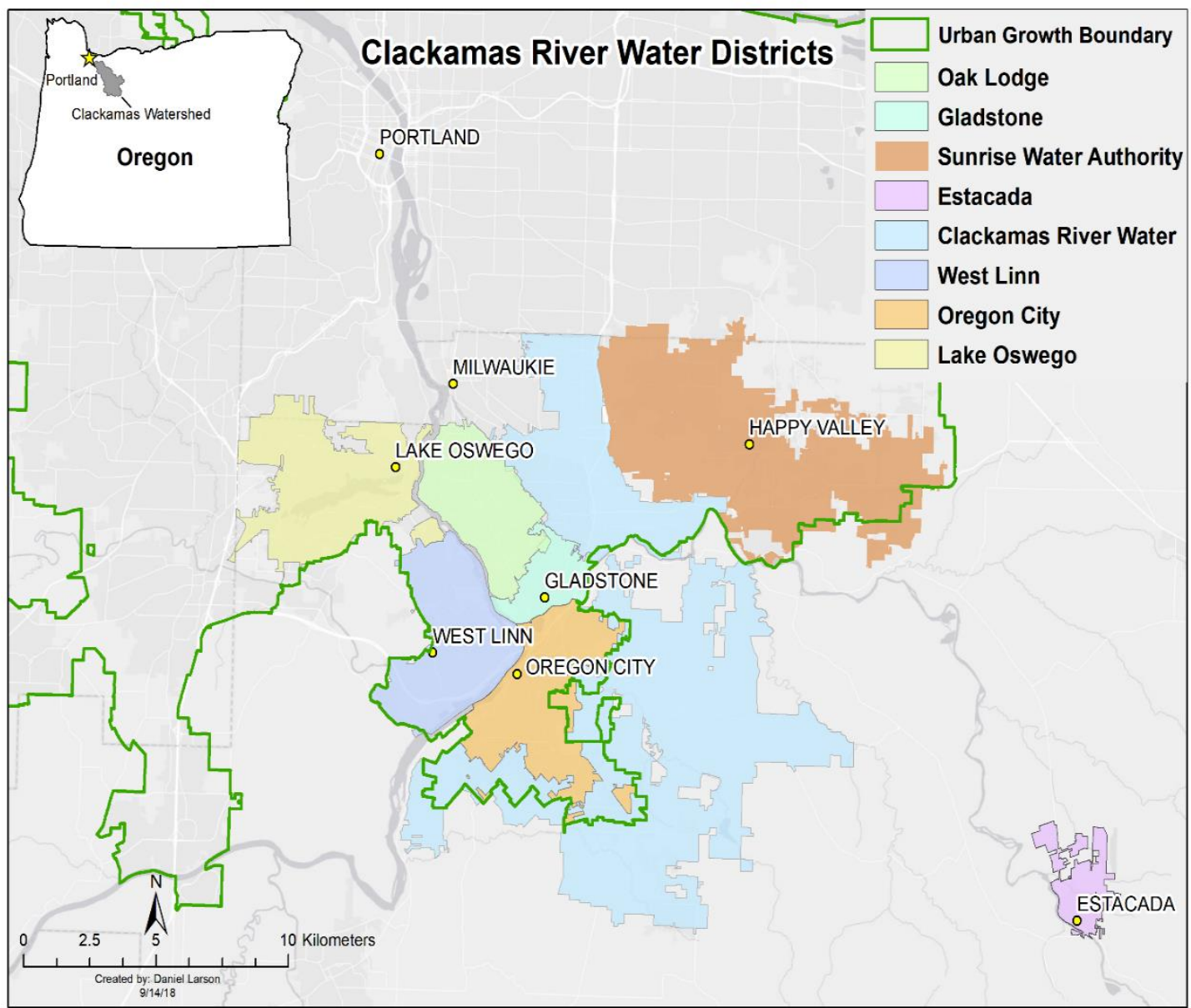

Figure 1-1. Study Area and Water Service Providers

Sampling and Data Collection 
Between March and June of 2016, we conducted a survey of a stratified random sample of 1,200 Clackamas County, Oregon, residents who were the customers of one of seven water providers that relied on the Clackamas River for drinking water. We used each water provider's water service boundary to clip the Oregon Assessor's Tax lot spatial dataset; only parcels exhibiting single-family residential (SFR) zoning. This was performed to obtain a sample of water customers that are likely to be responsible for paying their own water bill. For sampling purposes, the Oak Lodge, Gladstone, and Estacada water districts were aggregated into one district, given their smaller populations and similar sociodemographic characteristics.

The survey employed a four contact Dillman Tailored Design Method (Dillman, 2000) utilizing a mixed mode mail and web design. Initial postcards were sent to our sample inviting them to opt-in to our online questionnaire, paper surveys were sent two weeks later followed by another round of reminder postcards and paper surveys. The questionnaire consisted of 35 questions, more than half of which consisted of multi-item questions with Likert-style responses (Table 1-2). Questions in the survey themed primarily around the respondent's (1) knowledge of the Clackamas watershed, (2) their beliefs and attitudes related to the ecosystem services provided by the Clackamas River, (3) the management actions ratepayers support to maintain or enhance those ecosystem services, (4) their willingness to pay for source water protection, (5) attitudes and beliefs about water consumption, (6) knowledge and beliefs regarding climate change and water resources, and (7) respondent demographics such as income, political leanings, education, gender, age, and size of household (See Appendix B for survey questions).

WTP for a SWPP in the Clackamas Watershed was assessed in the questionnaire using a multiple bounded discrete choice format (Nielsen-Pincus et al., 2017; Welsh \& Poe, 1998). This 
section of the questionnaire contained three multi-item questions. The questions asked respondents' WTP for SWP activities in the Clackamas Watershed on private land, public land, or investment in existing water treatment infrastructure. We sought to elucidate if respondents had a preference of one form of water protection over another, whether those activities occurred on private land or public land, or if they would rather see resources allocated to upgrading the existing water treatment facilities. We asked respondents to rate their level of certainty for WTP at various bid levels $\$ 0.01$, $\$ 0.50, \$ 1.00, \$ 3.00, \$ 5.00, \$ 10.00$, for a water quality protection program in the Clackamas Watershed through a fee added to their monthly water utility bill (see Appendix A). Place attitudes were determined by a nine-item questionnaire measuring place attachment, place dependence, and place identity, and how these factors relate to the Clackamas Watershed. Previous research found this measure to provide an adequate concept of validity for measuring place attitudes (NielsenPincus et al., 2017).

Survey questions and coding survey responses

Respondent certainty for WTP was measured on a 5-point scale ranging from Definitely Yes, Probably Yes, Unsure, Probably Not, Definitely Not (Table 2). Response data were coded “1” to reflect responses where a "Definitely Yes" was selected and " 0 ”" for all other responses (Champ et al. 1997; Nielsen-Pincus et al. 2017).

Table 1-1. Data and Measures

\begin{tabular}{|c|c|}
\hline Survey Items & Scale \\
\hline Willingness to Pay & Binary scale, (0) not WTP and (1) for definitely WTP \\
\hline
\end{tabular}




\begin{tabular}{|c|c|}
\hline Place Attitudes & 5-point Likert scale ranging from Strongly Agree (4) to Strongly Disagree (0 \\
\hline Climate Knowledge & 5-point Likert scale ranging from Very Knowledgeable (4) to Not at all \\
knowledgeable (0)
\end{tabular}

Index creation

All exploratory factor analyses (EFA) were performed in R Studio version 3.5 using the “psych" package (Revelle, 2013). In an effort to confirm the underlying dimensions of the place attitude scale (Nielsen-Pincus et al., 2017) we performed and exploratory factor analysis. Some of the items were reverse coded for analysis. Three components with an eigenvalue greater than one were clearly identified. One question, "I don't really identify with the Clackamas Watershed", had a factor loading 0.36 and an item complexity score of 2.4. Therefore, this item was omitted from analysis. With this in mind, three place variables were calculated for each respondent (e.g. Place Identity, Place Attachment, and Place Dependence) ranging from 0 to 4. Indices for place identity, 
place attachment, and place dependence were created by taking the average score for each of the three measures for each respondent. (Appendix A) for a description of Place Attitude questions and factor loadings.

There were four questions in the questionnaire pertaining to climate change (Table 1-2). The first question was an attempt to gauge the general knowledge respondents had about climate change, the second aimed at assessing respondents' general beliefs about climate change, the third focused on perceived impacts to climate change, and the fourth gauged attitudes toward climate in the Pacific Northwest. An overall climate belief index score was created by taking the average climate belief score for each respondent, scores range from 0 to 3.7. A similar approach was utilized to generate a climate impacts index score. Beliefs regarding Pacific Northwest Climate were assessed using a four-item scale. We created an overall PNW Climate Beliefs Index score for each respondent by averaging responses across the four items resulting in a score ranging from 0 to 4 .

Income was measured by asking respondent how much income they made after taxes in 2014. Income ranged in bins beginning at $\$ 25,000$ to greater than $\$ 200,000$ in $\$ 25,000$ bins. During regression modeling, the log value of the midpoint of each bin with a pareto-tail adjustment was used to correct for extreme values in the unbounded high income bin (Nielsen-Pincus et al., 2017).

Watershed use was determined by asking how frequently respondents visit the watershed for various purposes. Responses were converted to an interval scale based on the frequency of each activity (e.g. weekly=52, monthly=12, every 3 months $=4$, every 6 months $=2$, once a year $=1$, never $=0$ ). The values for these six activities were summed to create a frequency of use score (Table 1-2). To rectify the skewed distribution, we used the natural logarithm of the frequency score in regression modeling. 
To ease the interpretation of respondent characteristics (Table 1-2) indexed variables such as place dependence, place attachment, place identity, climate beliefs, climate change impact beliefs, and PNW climate beliefs were grouped by "strong, neutral, and weak". All items were coded on a 5-point Likert scale, thus strong attitudes denote where respondents "Agree or Strongly Agree", neutral refers to "Neither agree nor disagree", and weak is where respondents "Disagreed or Strongly Disagreed".

Regression Analysis

To test the veracity of our research questions, we developed a mixed effects logistic regression model that employed a panel dataset to examine WTP at different payment scales, and each of the three watershed interventions (Private, USFS-Public, Water Treatment Upgrades) simultaneously. The dependent variable (y) was a binary response variable measuring willingness to pay coded either 1 (yes) or 0 (no) and was repeated for each bid amount over the three watershed intervention options. The model was created for "Definitely Yes" as previous research has shown that clarifying a respondents level of certainty in their donation response enables the differentiation between respondents that are actually WTP and those that are not (Champ, P. A., Bishop, R. C., Brown, T. C., \& McCollum, 1997). In a logistic regression, outcomes are modeled as log odds so that estimates can be easily converted and interpreted as odds of a respondent selecting "yes" or "no". We exponentiated log odds to create odds ratios which were then converted to predicted probabilities. We also created average water customer profiles by holding all variables at their means to determine Marginal Effects at Representative Values (MEARV). This enables the exploration of how significant variables in the model change WTP with unit increases or decreases. Our regression model was based upon the following equation: 
Level 1 Model:

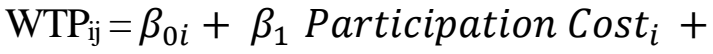

$$
\begin{aligned}
& \text { Participation Scenario } \left._{i} \text { (Participation Cost }_{i} * \text { Participation Scenario }_{i}\right)+
\end{aligned}
$$

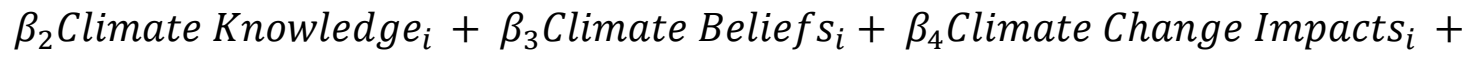

$$
\begin{aligned}
& \beta_{5} \text { PNW Climate Attitudes }_{i}+\beta_{6} \text { Place Identity }_{i}+\beta_{7} \text { Place Dependece }_{i}+ \\
& \beta_{8} \text { Place Attachment }_{i}+\beta_{9} \text { Age }_{i}+\beta_{10} \text { Education }_{i}+\beta_{11} \text { Political Attitudes }_{i}+ \\
& \beta_{12} \text { Income }_{i}+\varepsilon_{i}
\end{aligned}
$$

Level 2 models:

$\beta_{0 j}=\gamma_{00}+u_{0 i}$

We calculated different levels of participation cost ranging with different interaction terms to distinguish between each participation scenario. Therefore, willingness to pay for a given person is a function of participation cost, it's interaction with different treatment scenarios (e.g. private, public, water treatment upgrades) plus all other covariates and an error term. The Level 2 model assesses differences in baseline WTP to determine how individuals differ from average WTP.

\section{Results}

Response Summary 
A total of 406 completed questionnaires were returned for a $34 \%$ global response rate to our questionnaire from our sample population. Surveys were either returned by mail $(n=315)$ or completed by an online version of the questionnaire $(n=91)$. Additionally, we created a convenience sample by posting a link to the questionnaire on each of the water provider websites, to which an additional 60 ratepayers responded. Nineteen incomplete responses were removed, resulting in a final sample size of 447 . The overall nonresponse rate within the survey was $20 \%$.

Respondents were typically middle-aged (median age $=59$ ), college educated (bachelor's degree), homeowners that had a household income between $\$ 75,000-\$ 99,000$, with more liberal political leanings. These findings differ slightly from Clackamas County demographic data obtained from the US Census American Community Survey Profile (2013-2017). Our survey respondents' median age is higher than the US Census American Community Survey Profile (2013-2017) reported median age of 41 years for Clackamas County. However, our respondents are homeowners, as we felt they would be most likely in paying their own water bill. Homeowners over the age of 55 comprise $55 \%$ of the population in Clackamas County. Approximately $59 \%$ of respondents reported possessing a college degree or graduate degree, this is slightly higher than the average for Clackamas County homeowners (43\%) (Table 1-3). Respondents predominately reported a 2014 household income of $\$ 75,000-\$ 99,000$, our sample is representative of homeowners with a median household income of $\$ 87,689$ for ages 45 to 64 . Clackamas County voter registration in November 2016 was 36\% Democrat, 31\% Republican, and 33\% other, which is similar to our findings with the exception of a skew towards liberal respondents (44\%). We make the assumption that party affiliation with Democrat denotes liberal and Republican denotes conservative. 
Table 1-2. Clackamas River drinking water ratepayer respondent characteristics summarized by category. Non-responses were omitted from calculation.

\begin{tabular}{|c|c|c|c|}
\hline Respondent Characteristics & & & \\
\hline Age mean and range $(n=396)$ & 59 (25 to 106$)$ & Frequency of Watershed Use $(n=273)$ & \\
\hline Educational Attainment $(\mathrm{n}=395)$ & & Never & $21 \%$ \\
\hline$<\mathrm{HS}$ & $<1 \%$ & Once every Year & $14 \%$ \\
\hline HS diploma & $11 \%$ & Once every 6 Months & $17 \%$ \\
\hline Associate's degree & $19 \%$ & Once Every 3 Months & $19 \%$ \\
\hline Some college & $10 \%$ & Once a Month & $14 \%$ \\
\hline College degree & $30 \%$ & Once a Week & $15 \%$ \\
\hline Graduate or professional degree & $29 \%$ & Place Dependence Index $(\mathrm{n}=411)$ & \\
\hline Household Income ( $\mathrm{n}=356)$ & & Strong Place Dependence & $2 \%$ \\
\hline$<\$ 25,000$ & $4 \%$ & Medium Place Dependence & $46 \%$ \\
\hline$\$ 25,000-\$ 49,999$ & $13 \%$ & Weak Place Dependence & $42 \%$ \\
\hline$\$ 50,000-\$ 74,999$ & $16 \%$ & Place Attachment Index $(n=420)$ & \\
\hline$\$ 75,000-\$ 99,999$ & $19 \%$ & Strong Place Attachment & $2 \%$ \\
\hline$\$ 100,000-\$ 124,999$ & $15 \%$ & Medium Place Attachment & $43 \%$ \\
\hline$\$ 125,000-\$ 149,999$ & $6 \%$ & Weak Place Attachment & $40 \%$ \\
\hline$\$ 150,000-\$ 174,999$ & $9 \%$ & Place Identity Index (n=407) & \\
\hline$\$ 175,000-\$ 199,99$ & $5 \%$ & Strong Place Identity & $6 \%$ \\
\hline$>\$ 200,000$ & $12 \%$ & Medium Place Attachment & $56 \%$ \\
\hline Political leanings ( $\mathrm{n}=398$ ) & & Weak Place Attachment & $18 \%$ \\
\hline Very Liberal & $14 \%$ & Climate Beliefs ( $\mathrm{n}=374)$ & \\
\hline Somewhat Liberal & $30 \%$ & Strong Climate Beliefs & $7 \%$ \\
\hline Neither Conservative nor Liberal & $28 \%$ & Medium Climate Beliefs & $50 \%$ \\
\hline Somewhat Conservative & $20 \%$ & Weak Climate Beliefs & $43 \%$ \\
\hline Very Conservative & $8 \%$ & Climate Change Impact Beliefs $(n=371)$ & \\
\hline Climate Knowledge $(n=374)$ & & Strong Beliefs & $2 \%$ \\
\hline Knowledgeable & $75 \%$ & Medium Beliefs & $65 \%$ \\
\hline Some Knowledge & $18 \%$ & Weak Beliefs & $33 \%$ \\
\hline \multirow[t]{4}{*}{ Not Knowledgeable } & $7 \%$ & PNW Climate Beliefs (n=370) & \\
\hline & & Strong Beliefs & $51 \%$ \\
\hline & & Medium Beliefs & $40 \%$ \\
\hline & & Weak Beliefs & $9 \%$ \\
\hline
\end{tabular}

\section{Use of the Clackamas River Watershed and its natural areas was skewed heavily towards} less intense use with $50 \%$ of respondents visiting the watershed twice per year or less and $21 \%$ of 
respondents indicating they have never visited the watershed in the last year. Respondents reported neutral to weak place dependence, attachment, and identity attitudes towards the Clackamas River Watershed with an average score of 2.03 and $46 \%, 43 \%, 56 \%$ neutral attitudes and $42 \%, 40 \%$, and $18 \%$ weak place attitudes, respectively. On the issue of respondent's knowledge about climate change, $75 \%$ of respondents reported being knowledgeable. When respondents were asked about their overarching beliefs about the impacts and causes of climate change, $49 \%$ of respondents demonstrated neutral climate beliefs and $43 \%$ of respondents had weak climate beliefs. Ratepayers also exhibited neutral beliefs about the impact of climate change on water resources (63\%), negative beliefs about climate change adversely impacting their quality of life $71 \%$, and neutral beliefs $(66 \%)$ about the notion that PNW climate is starting to exhibit patterns of more droughtprone areas.

Influence of Bid Levels and Intervention Scenarios on Willingness to Pay

While intuitive, the coefficient "Bid level", for the Definitely WTP model is significant ( $\alpha<$ 0.001). A two unit increase in bid amount, from $\$ 1$ to $\$ 3$ for instance, reduces WTP by $18 \%$ (Table 1-4). Review of the raw findings of survey items pertaining to WTP show $41 \%$ of respondents are “Definitely WTP” \$1/month for interventions on private land, and 14\% WTP \$5/month. On public land $42 \%$ of respondents were WTP $\$ 1 /$ month and $13 \%$ were WTP $\$ 5 /$ month. For investing in existing water treatment infrastructure, $45 \%$ of respondents were WTP $\$ 1 /$ month and $13 \%$ were WTP \$5/month. 
Table 1-3. Logit Regression Modeling results and predicted probabilities of willingness to pay on monthly water utility bills for source water protection in the Clackamas River watershed $(n=447)$.

\begin{tabular}{lccccc}
\hline & & & Predicted & & \\
& Log Odds & Odds & Probabilities & Z-score & \\
\hline (Intercept) & -0.072 & 0.931 & 0.482 & -0.087 & \\
Bid Level & -1.500 & 0.223 & 0.182 & -6.503 & $* * *$ \\
Participation scenario - USFS & 0.150 & 1.161 & 0.537 & 0.327 & \\
Participation scenario - Water Treatment Plant & 0.575 & 1.777 & 0.640 & 1.235 & \\
Climate knowledge & 0.183 & 1.200 & 0.546 & 0.202 & \\
Climate beliefs & 2.858 & 17.421 & 0.946 & 1.971 & $*$ \\
Climate Change Impacts & 4.103 & 60.525 & 0.984 & 2.799 & $* *$ \\
PNW climate worsening & 0.257 & 1.293 & 0.564 & 0.272 & \\
Watershed use frequency & 0.595 & 1.813 & 0.645 & 1.357 & \\
Place Identity & -0.307 & 0.736 & 0.424 & -0.312 & \\
Place Dependence & 0.096 & 1.100 & 0.524 & 0.104 & \\
Place Attachment & -1.000 & 0.368 & 0.269 & -0.950 & \\
Age & -0.025 & 0.975 & 0.494 & -0.559 & \\
Education & 0.725 & 2.066 & 0.674 & 1.421 & \\
More Conservative & -0.611 & 0.543 & 0.352 & -0.769 & \\
Income & 0.000 & 1.000 & 0.500 & -1.407 & \\
Bid level: participation scenario - USFS & 0.515 & 1.673 & 0.626 & 2.166 & $*$ \\
Bid level: participation scenario -Water Treatment Plant & 0.389 & 1.475 & 0.596 & 1.609 & \\
\hline
\end{tabular}

The type of watershed intervention scenario (Private lands, US Forest Service, or Water Treatment Plant upgrades) were not significant, indicating that respondents do not have a preference for where these interventions occur. We calculated Marginal Effects at Representative Values (MEARV) to compute profiles of water customers. Holding all other covariates at their means, the model predicts that respondents are 29\% WTP \$1 to support source water protection on private land, $44 \%$ on public land, and have a 52\% probability invest in water treatment infrastructure 
upgrades. In comparison, when bid level was increased to $\$ 5$, respondents were $0 \%, 2 \%$, and $1 \%$ WTP for source water protection on private land, public land, and for water treatment upgrades (Table 1-4).

Table 1-4. Marginal Effects at Representative Values (MEARV) for \$1 \& \$5 Bid Amounts and Scenarios

\begin{tabular}{lcccc}
\hline Bid Level & \multicolumn{3}{c}{$\underline{\text { \$1 }}$} & \multicolumn{2}{c}{$\underline{\text { O5 }}$} \\
\hline & Odds & Probability & Odds & Probability \\
Private Land & 0.41 & 0.29 & 0.00 & 0.00 \\
Public Land (USFS) & 0.79 & 0.44 & 0.02 & 0.02 \\
Water Treatment Upgrades & 1.06 & 0.52 & 0.01 & 0.01 \\
\hline
\end{tabular}

Examining the relationship between participation cost and the probability of WTP on private land revealed 29\% WTP at \$1; 2.5\% WTP at \$3, and 0\% WTP at \$5. A graph of the probability of WTP on private land (Figure 1-2) exhibits 29\% WTP at a bid level of \$1, approximately $8 \%$ probability of WTP at $\$ 2$, and participation willingness falling rapidly after the $\$ 3$ bid level. 


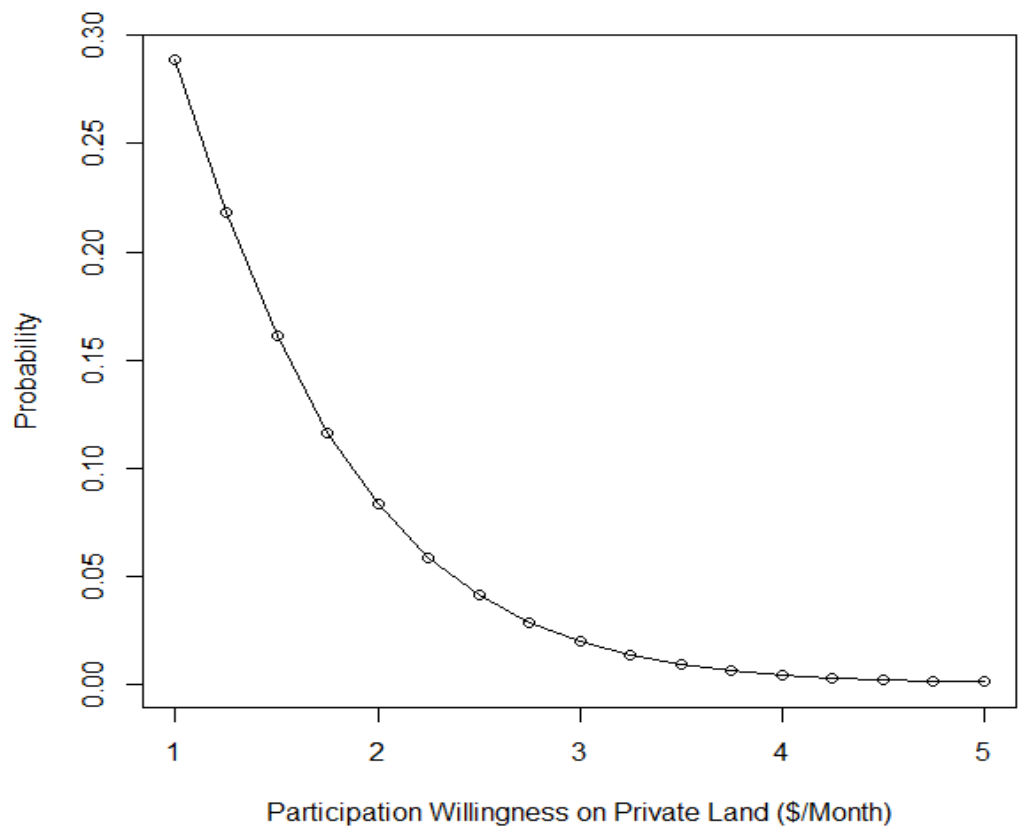

Figure 1-2. Probability of Participation Willingness of increasing bid levels on Private Land.

\section{Climate Change Influences on WTP}

We hypothesized that concerns about climate change and the future availability of water in the PNW region be a predictor of WTP for source water protection. While knowledge about climate change, and change to the PNW climate were not significant, general beliefs about the causes of climate change and beliefs that climate change would result in negative impacts on the Clackamas watershed were both significant predictors of WTP in our model. Holding all other variables at their means, an increase in one standard deviation $(\mathrm{M}=2.65, \mathrm{SD}=0.70)$ above the mean resulted in 77\% WTP $\$ 1$ on private land, whereas one standard deviation below the mean reduced WTP by $76 \%$ (e.g. 1.2\%). 


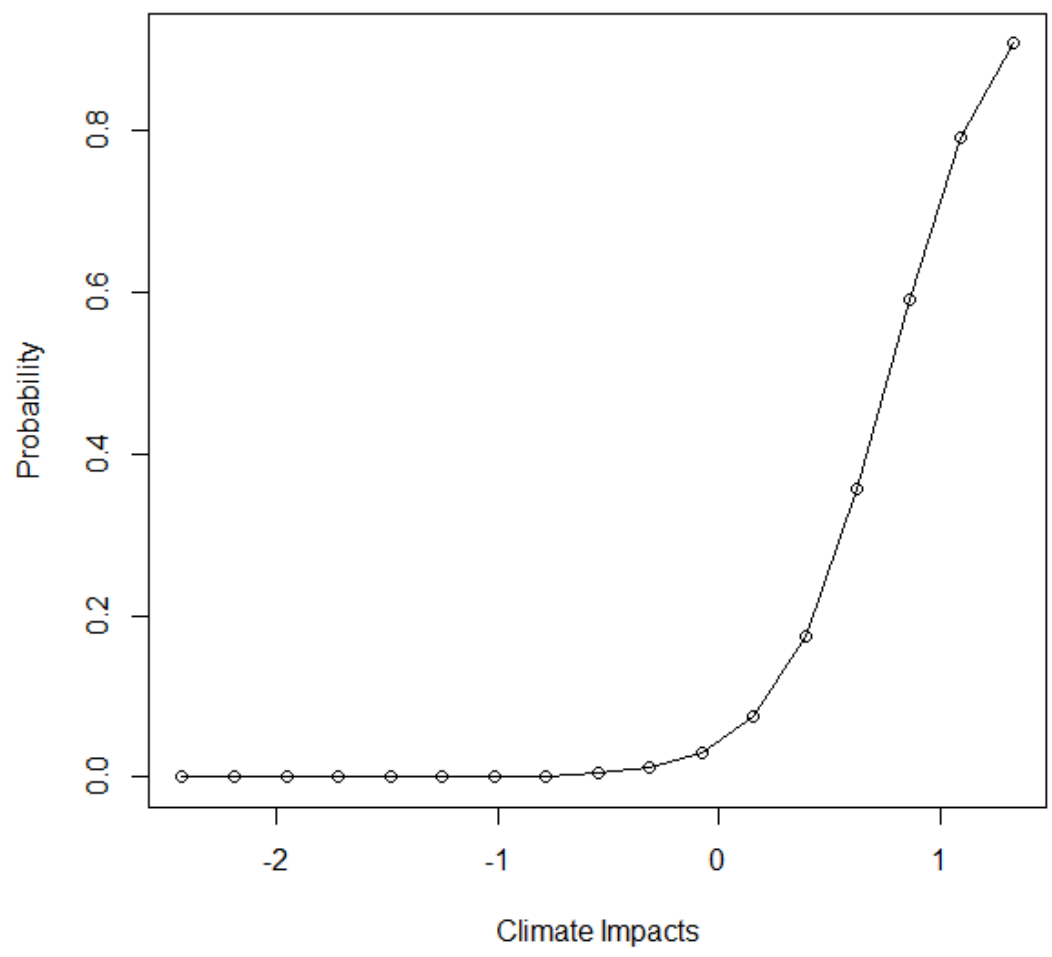

Figure 1-3. Probability of Participation Willingness based on strength of Climate Impact Attitudes.

There is a clear association between strength of Climate Impact Attitudes and the probability of WTP (Figure 1-3). The figure above depicts the association on the variables centered for analysis. If we examine the range of the raw values $(\min =0.25, \max =4)$ we can see as strength of climate impact attitudes increases, so does the probability of WTP \$1 on private land. Climate Beliefs were also significant, as a respondent disagrees with general beliefs and causes of climate change to agreement $(\mathrm{M}=2.03, \mathrm{SD}=0.59)$, probability of WTP $\$ 1 /$ month for $\mathrm{SWP}$ on private land goes from $38 \%$ to $95 \%$.

Other Influences on WTP 
In addition to bid amount, the other predictor variables control for frequency of watershed use, place attitudes, education, income, age, and political leanings and the interaction between bid level and participation scenario (Table 1-4). Bid level and the interaction with watershed protection activities occurring on US Forest Service property compared to private land, was a significant predictor in our model $(\alpha=0.03)$. Our model predicts that respondents are 97\% WTP $\$ 1 /$ month for watershed protection on US Forest Service land.

\section{Discussion}

The purpose of this research was to test our hypotheses regarding the influence of climate change risk perceptions on willingness to pay for source water protection. The theory underpinning this hypothesis is the Values, Beliefs, Norms (VBN) Theory of environmental concern and behavior (Dietz, Dan, \& Shwom, 2007). Our analysis supports our hypothesis that climate change perceptions were significant predictors of WTP, specifically the measure of ratepayer's perceptions of adverse climate impacts to the Clackamas Watershed, which resulted in a 76\% increase in WTP on private land as respondents evoked more concern over climate impacts to the watershed. This supports Dietz et al. (2007) theory that if individuals acknowledge environmental conditions pose threats to others or the environment, they are more likely to engage in behaviors to mitigate these effects. This confirmed other studies showing the close relation between climate change perception and their willingness to pay to protect water resources. Our findings support those of Akter et al. (2011) found that respondents WTP for climate mitigation is significantly influenced by their beliefs in future temperature rise and climate degradation. More specifically, the level of concern for local-level impacts due to climate, mediate the relationship between place attachment, water conservation, and climate beliefs (Brownlee et al., 2014). In addition, individuals that perceive long 
term changes in climate are significantly more WTP to reduce these risks than those that did not perceive any change (Veronesi et al., 2013).

The insignificance of place attitudes on WTP may be due to a variety of factors. In two of the water districts, a large portion of respondents indicated that they did not know their drinking water came from the Clackamas River (38\% of residents in Sunrise Water Authority and $41 \%$ of residents in Lake Oswego.) This lack of understanding around the source of respondent's water may explain why they did not feel particularly motivated to support efforts to protect the Clackamas River. This lack of awareness could be due to the geographic separation across the Willamette River, for the Lake Oswego water district. The second explanation could be the lack of frequent use and activities pursued while in the watershed. Approximately $52 \%$ of respondents revealed that they visited the watershed less twice a year or less, while $21 \%$ never visited the watershed. This is likely to be associated with the fact that the Portland metro region may offer substitute locations for recreation (e.g., Willamette River, Forest Park, Mt. Hood). This infrequent use may also explain why respondents don't feel much of an emotional or physical connection to the place. Perhaps the unique biophysical, social, economic, and political backdrop of the Clackamas River watershed does not lend itself well to an assessment of place-based attitudes on WTP. As mentioned previously, within the context of this study, watershed use frequency may serve as a suitable proxy for place attachment. Previous researchers have pointed out that place-attitudes are malleable and an artifact of social construction (Nielsen-Pincus et al., 2017; Stokowski, 2002), making them subject to manipulation by outreach and education. Perhaps this is still a viable entry point for managers interested in promoting a source water protection program. The Portland, Oregon Metro region is growing rapidly at $1.77 \%$ per year (Metro, 2017). This rapid growth and influx of new residents 
expanding into growing suburban areas of the Clackamas Watershed may denote that many of the regions' new residents have not had the time to cultivate a strong attachment to the watershed given their recent arrival.

A key finding of this research was that climate change perceptions have the potential to be significant predictors of WTP for source water protection. Previous research has found that there is a linkage between climate change concern and behavior change. In a cross-sectional study conducted on Portland, OR and Houston, TX, residents regarding awareness, concern, and behavior change related to climate change, researchers found that that $90 \%$ of Portland, OR residents have an elevated concern over climate change, and concern about climate change was a significant predictor of changed behavior and the adoption of climate mitigation strategies. These strategies include reduction in energy use, reduction in gasoline consumption, and recycling (Semenza et al., 2008). Our findings support those of Semenza et al. (2008), that individuals with concern over climate change are more likely to engage in behaviors to mitigate climate impacts (e.g. supporting watershed protection programs). The novel contribution of our research is the emphasis of climate change and WTP for source water protection. To our knowledge, this linkage is absent in the literature. Our research shows that concern over climate change impacts to the provision and quality of drinking water have strong average marginal effects on WTP $(81 \%)$. It seems that longheld beliefs of elevated climate concerns and increased national debate around the topic of climate change have motivated drinking water customers to support efforts to protect water supplies in an effort to mitigate the adverse effects of climate change.

Opportunities for theoretical SWPP Program Design 
Concerns over climate impacts offer some illuminating insights for approaches towards watershed protection and the message framing required in such campaigns. How are water managers able to leverage these concerns about the future of water supply? Perhaps they can underscore the fragility of the water system and the change the watershed is likely to endure in the future? Looking beyond outreach campaigns, this study presents the opportunity to discuss alternative approaches to SWPP program design. Results from our survey provide illuminating insights for a theoretical SWPP design. Within our questionnaire, respondents were asked how much they would be WTP for SWP. The highest bid level with majority support (62\%), was \$1 per month, with support declining as bid level increases. Hypothetically, what if ratepayers were automatically enrolled in contributing $\$ 1 /$ month to watershed protection instead of given the "check a box" option to pay a fixed amount towards watershed protection on a monthly water utility bill? This type of automatic enrollment is known as "opt-out", compared to more common "opt-in" programs such as the "check a box" program outlined above. This form of automatic enrollment, or “opt-out" programs have garnered ample research attention from economists and psychologists for important issues such as organ donation and company $401 \mathrm{k}$ retirement plans. The guiding principle behind these programs is that people tend to follow the default in a variety of domains. Policymakers therefore have a broad range of control with important outcomes when deciding what a default option should be (Johnson \& Goldstein, 2004; Madarin \& Shea, 1997; McKenzie, Liersch, \& Finkelstein, 2006). Perhaps constructing a SWPP around opt-out principles would result in greater participation and fundraising, which may improve the efficacy and sustainability of

\section{SWPP.}


Opportunities for future research include evaluating WTP of home-renters. Renters were intentionally excluded from our sample as we felt that home owners would be more likely to be responsible for paying their water bill. It could be possible that home owners may have a stronger place attachment and more knowledge of the region and changes in climatic patterns biasing them towards WTP for source water protection. Future research should seek to assess the generalizability of support for source water protection studies. Watersheds are a complex tapestry of natural, social, and physical attributes. A similar study conducted in the McKenzie Watershed outside of Eugene, OR found that place attitudes were overwhelmingly predictive of ratepayers WTP for source water protection. However, place-based studies can be limited by their generalizability (Nielsen-Pincus et al., 2017). In this study, perceptions of adverse climate impacts where the primary predictor of WTP. However, given the evidence of Portland residents environmental awareness and heightened climate change concern (Semenza et al., 2008), results may not be generalizable to other regions with different environmental and climate risk prerogatives.

\section{Conclusions}

The motivation for the development of a source water protection program in the Clackamas River watershed was not an immediate or looming regulatory threat. Nor was it motivated by declining water quality. The motivation was to maintain the Clackamas River a high-quality drinking water source by identifying and preventing harmful impacts and promoting healthy watershed stewardship. It would seem that more work is required to achieve the second objective. Unlike previous research on place attitudes and source water protection, we did not find sense of place to be a significant predictor of WTP to support watershed protection. Interestingly, political 
attitudes, education, and strong place attitudes did not have a significant influence on customer WTP. The strongest predictors of WTP for source water protection were bid level, general beliefs about climate change, and strong attitudes about the negative impacts from climate change. The location of watershed intervention (Private, Public, Water treatment plant upgrades) were also not significant predictors of WTP. Results of bid level and support are intuitive, as bid level increased, support for water protection decreased. Our findings show that people do not have much of a connection to the watershed evidenced by their lack of knowledge regarding where they obtain their drinking water, and infrequent to non-existent use of the areas within the watershed, resulting in a lack of attachment and desire to protect the watershed. These attitudes are not set in stone. Water managers and their collaborators are in a unique position to change these attitudes. Water managers can conduct outreach and informational campaigns underscoring the unique character of the watershed and the multitude of ecosystem service benefits it provides. The PMA abounds with spaces for outdoor recreation, perhaps encouraging more people to explore, hike, and visit the natural areas of the watershed will help achieve this end.

Our study also found an explicit connection between general climate beliefs and elevated concerns over adverse climate change impacts to water supply, quality, and quality of life, and WTP for source water protection. These findings have interesting implications for researchers and practitioners, people may not have much of a personal connection to the watershed but they clearly demonstrate a concern over the provision of water. This offers many unique opportunities for engagement by water providers. By highlighting the fragility of the watershed and the uncertainties of climate change and urban growth on future water supply, providers and conservation groups have the opportunity to promote watershed protection and reduction in household water 
consumption programs. Ultimately, promoting healthy watershed stewardship through outreach and education will require emphasizing the multitude of benefits watersheds provide combined with the potential threats they face, in order to foster a sense of identity and care for such a valuable and pristine resource. 


\title{
Chapter 2: Water Conservation Attitudes and Behavior: A Path-Analysis
}

\begin{abstract}
The increasing threat from climate change on water resources has prompted water managers to initiate household water conservation programs, and effective program design requires an understanding of water conservation attitudes. We examined the attitudinal and behavioral factors of household water consumption in the Portland Metropolitan Area (PMA). A path analysis showed that water conservation results from a causal chain of pro-water conservation attitudes and the presence of water efficient household appliances when controlling for property size. These attitudes and behaviors resulted in a water savings of 183 liters/day. These findings provide valuable insights on message framing and program design for water managers considering the implementation of water conservation programs.
\end{abstract}

Keywords: Water conservation, climate change, water use behavior, path analysis

\section{Introduction}

Global population increase, urban growth, and the advent of climate change, have created disparities between the availability of fresh water sources and demand for consumption (Seyranian, Sinatra, \& Polikoff, 2015). Policy makers are increasingly concerned with securing future water sources and managing water demand, while promoting initiatives designed to conserve water (Guhathakurta \& Gober, 2007; B. S. Jorgensen, Martin, Pearce, \& Willis, 2014).

The United States has seen an increase in water conservation outcomes as a result of regulatory policy initiatives, improvements in water efficiency technology (Heejun Chang, 2017), and targeted social marketing campaigns such as "Turn off the Tap" (Straus, Chang, \& Hong, 
2016). Despite these advances, the combination of rapid urban growth, climate change, and population increase pressure test the vulnerability of many municipal water supply systems (Larson et al. 2013). In the absence of management strategies designed to access water from new sources, demand management through water conservation programs are another appropriate option. Understanding the household level factors that lead to conservation outcomes can improve water resource management and resultant water conservation outcomes (Brownlee et al., 2014). Moreover, understanding water consumers' beliefs about climate change and other environmental issues, and attitudes towards conservation can improve outreach, policy, and education programs that are critical for effective water resource management (Brownlee et al., 2014).

The primary drivers of water conservation outcomes in the literature (Table 2-1) can be broadly grouped into three categories: 1) The influence of attitudes on behavior (Bamberg \& Möser, 2007; Corral-Verdugo \& Frías-Armenta, 2006; Lowe, Lynch, \& Lowe, 2015; Straus et al., 2016; Laura A. Warner, Lamm, \& Kumar Chaudhary, 2018; Laura A. Warner, Lamm, Rumble, Martin, \& Cantrell, 2016; Willis, Stewart, Panuwatwanich, Williams, \& Hollingsworth, 2011a); 2) Structural, technological, and policy instruments such as building size, water efficient appliances, and zoning requirements (H Chang, Parandvash, \& Shandas, 2010; Dias, Kalbusch, \& Henning, 2018; Hong \& Chang, 2014; L. House-Peters, Pratt, \& Chang, 2010; Ojeda, Álvarez, Ramos, \& Soto, 2016; Saurí, 2013; Shandas \& Parandvash, 2010; Villar-Navascués \& Pérez-Morales, 2018); 3) Lawn care (Hayden, Cadenasso, Haver, \& Oki, 2015; Polsky et al., 2014; Willis, R.M. Stewart, R.A. Giurco, D.P. Talebpour, M.R. and Mousavinejad, 2011). Many studies focus on attitudes since they can be subject to manipulation through outreach programs in ways structural and policy 
components of water conservation are not. We will focus primarily on attitudinal components of water conservation as they are of primary interest to our study.

Water conservation decisions are partially explained by attitude theory, which proposes that specific attitudes influence intentions to engage in a specific behavior, and these intentions are critical precursors to planned behavior (Ajzen, 1991; Nielsen-Pincus et al., 2017). Positive attitudes, strong subjective norms, and high perceived behavioral control are common measures in attitude theory and numerous studies have found them to be significant predictors of water conservation (Lowe et al., 2015; Laura A. Warner et al., 2018, 2016). It is critically important to understand the role of attitudes towards water conservation, and how they are adopted by communities and imparted to individuals (Straus et al., 2016). Previous studies show that pro-conservation attitudes and water conservation outcomes are a byproduct of a causal chain of attitudes and behaviors, and the strength of pro-conservation attitudes are the most significant predictor of actual conservation behaviors (Bamberg \& Möser, 2007; Straus et al., 2016). Investigation of water conservation attitudes in Mexico found that strong personal normative beliefs had a positive water conservation outcome while anti-social behavior impeded conservation (Corral-Verdugo \& Frías-Armenta, 2006). Research into water consumption on the Spanish coast found that birthplace and water conservation attitudes were significant predictors of water consumption (García de Jalón et al., 2013). Actual water use is influenced by perceptions of how others use water both wasting and conserving. Willis et al. (2011) found that water customers with very positive environmental and water conservation attitudes use approximately $169.0 \mathrm{~L}$ day less than customers with moderately positive attitudes (Willis et al., 2011a). Conversely, a study conducted in Australia's Gold Coast of 132 detached households containing Smart Meters found that respondents exhibiting positive 
environmental and conservation attitudes were prone to exhibiting less water consumptive behavior (Willis et al., 2011a). Studying the impact of attitudes on behavior is not without its practical limitations. Previous research by Straus, Chang, and Hong (2016) noted that it can be difficult to determine if water conservation policies promote water conservation or if water conservation policies are evidence of an already environmentally aware community.

The structural elements of water conservation such as building size, technology, and zoning restrictions also influence water conservation. The size, age, and density of homes has a significant influence on water consumption, with less consumption occurring in high-density older neighborhoods (Chang, Parandvash, \& Shandas, 2010). A study exploring the interaction of structural attributes and sociodemographic characteristics in Hillsboro, Oregon found that indoor water use is dependent upon building size and outdoor water use is influenced by education level and the size of the outdoor space (L. House-Peters et al., 2010). In addition, Single Family Residential (SFR) zoning patterns are responsible for the majority of water consumption, while increased residential density causes a significant reduction in water consumption (Shandas \& Parandvash, 2010). A review of water conservation programs conducted in Europe found that urban form (e.g. density) is an important factor of household water consumption and conservation in European cities (Saurí, 2013). Structural attributes such as number of floors, units, age of property, number of residents per unit, building value, and presence of a pool have also been shown to be significant predictors of water consumption (Dias et al., 2018; Villar-Navascués \& PérezMorales, 2018). Analysis of determinants of water consumption in Hermosillo, Mexico showed that number of bathrooms, cost of water, presence of water meters within home, use of bottled water, and number of female inhabitants in the household were significant predictors of domestic 
water consumption (Ojeda et al., 2016). Hong and Chang (2014) went further and examined the interplay between building attributes, sociodemographic variables, and behavioral characteristics in the Portland, Oregon region across two scales. Researchers found that $41 \%$ of the variation in Single Family Residential (SFR) water consumption is explained by average building size, household attitudes towards water conservation, the level of community engagement, and the presence of native plants in outdoor yard areas. Their findings underscore the importance of community engagement programs to encourage water conservation behaviors (Hong \& Chang, 2014)..

Outdoor water use explains much of the seasonal variation in water consumption as water customers are likely to use more water during the summer in performance of lawn care activities. In a survey of lawn care behavior within six major U.S. cities, (Polsky et al., 2014) researchers found that lawn care behavior is highly varied between cities, supporting the argument of Willis (2011) that water consumption behavior studies are highly contextual due to different community attitudes towards water (Polsky et al., 2014). Aesthetics are a key motivator of landscape decision making, and policy makers may attempt to promote new aesthetic norms that incorporate water conservation BMPs in lawn care practices (Hayden et al., 2015).

Building upon the research of Brownlee et al. (2014) examining the influences of climate change beliefs on water conservation attitudes, and how water conservation attitudes influence water use behavior (Straus et al., 2016), the novel contribution of this research is to combine the dimensions of perceived climate risks, how these attitudes articulate with water conservation attitudes, and result in observed water conservation outcomes. We seek to build on this novel approach by examining how perceived climate change risks influence water conservation behavior. 


\begin{tabular}{|c|c|c|c|c|}
\hline Authors & $\begin{array}{c}\text { Date } \\
\text { (Year) }\end{array}$ & Study Area & Methods & Key Findings \\
\hline Warner et al. & 2018 & Florida, U.S. & Online survey & $\begin{array}{l}\text { Positive attitudes, strong subjective } \\
\text { norms, and high perceived behavioral } \\
\text { control lead to higher engagement in } \\
\text { outdoor water conservation and water } \\
\text { quality protection behavior. }\end{array}$ \\
\hline $\begin{array}{l}\text { Villar-Navascués } \\
\text { and Pérez-Morales }\end{array}$ & 2018 & $\begin{array}{l}\text { Spanish } \\
\text { Mediterranean } \\
\text { coast }\end{array}$ & $\begin{array}{c}\text { OLS regression; } \\
\text { Geographically Weighted } \\
\text { Regression (GWR) }\end{array}$ & $\begin{array}{l}\text { Most influential variables predicting } \\
\text { water consumption were percentage } \\
\text { of second homes and properties with } \\
\text { pools. }\end{array}$ \\
\hline Dias et al. & 2018 & Brazil & Regression analysis & $\begin{array}{l}\text { Number of units, number of floors, } \\
\text { age of property, number of residents } \\
\text { per apartment were predictive of } \\
\text { high-water consumption. As building } \\
\text { value increased, so did water } \\
\text { consumption. }\end{array}$ \\
\hline $\begin{array}{c}\text { Ojeda de la Cruz et } \\
\text { al. }\end{array}$ & 2016 & $\begin{array}{l}\text { Hermosillo, } \\
\text { Mexico }\end{array}$ & Mixed methods; Survey & $\begin{array}{l}\text { Significant determinants of domestic } \\
\text { water consumption }(n=403) \text { were } \\
\text { number of bathrooms, cost of water, } \\
\text { measured service supply, use of } \\
\text { bottled water, number of female } \\
\text { inhabitants in household. }\end{array}$ \\
\hline Warner et al. & 2016 & Florida, U.S. & $\begin{array}{l}\text { Survey; Segmentation } \\
\text { analysis }\end{array}$ & $\begin{array}{l}\text { Among residential landscape } \\
\text { irrigation users, stung normative } \\
\text { beliefs, attitudes, and perceived } \\
\text { behavioral control were variables that } \\
\text { were significant in clustering and } \\
\text { demonstrated the highest water } \\
\text { conservation behavior. }\end{array}$ \\
\hline Ghosh et al. 2016 & 2016 & Delhi, India & $\begin{array}{l}\text { survey, choice } \\
\text { experiments }\end{array}$ & $\begin{array}{l}\text { Increased use of household } \\
\text { appliances and water conservation } \\
\text { behavior reduced water consumption } \\
\text { at the expense of increased energy } \\
\text { consumption. }\end{array}$ \\
\hline Toole et al. & 2016 & NA & literature review & $\begin{array}{l}\text { Climate change adaptation and } \\
\text { associated water conservation has } \\
\text { been shown to happen haphazardly, } \\
\text { as people respond to stimuli other } \\
\text { than climate change. }\end{array}$ \\
\hline Carlton et al. & 2015 & US Midwest & $\begin{array}{l}\text { online survey of } \\
\text { agricultural advisors }\end{array}$ & $\begin{array}{l}\text { Climate change beliefs nor adaptation } \\
\text { attitudes changed significantly due to } \\
\text { drought. Extreme events may not be } \\
\text { enough to shift public attitudes } \\
\text { regarding climate beliefs. Within the } \\
\text { context of large-scale commercial } \\
\text { agriculture. }\end{array}$ \\
\hline
\end{tabular}


Lee et el. $2015 \quad$ Global Survey of 119 countries

Lowe et al. $2015 \quad$ Australia

Atari

2014

Hong and Chang

2014

Jorgensen et al.

2014

South

Australia,

Australia

Polsky et al. 2014 Six U.S. cities Telephone survey

Brownlee et al.

Lake Hartwell, South Carolina

mixed methods; survey
Globally, the strongest predictor of climate change awareness is educational attainment.

Understanding the anthropogenic cause of climate change is the strongest predictor of climate risk perceptions. Factors of public awareness and risk perceptions vary greatly between nations.

Individuals will opt to not save water if it means compromising aesthetics. Social marketing campaign aimed at reducing water consumption by appealing to attitudes towards water consumption. Perceived behavioral control was a significant predictor of behavioral intent and attitudes have the greatest effect upon intentions to consume less water.

Participants indicated curtailment over efficient technological improvements for personal water conservation. Participants grossly underestimated their water use by a factor of 2

Household size and pricing attitudes were the most significant predictors of individual household water use.

Household water consumption is explained by building size, household water conservation attitudes, community engagement, presence of native plants in yard.

U.S. lawncare and irrigation practices vary greatly by city.

Concern for local-level drought impacts is significant and mediates relationships between place attachment, awareness of drought impacts, beliefs in climate change, and water conservation attitudes. Urban form is an important influence on household water consumption and conservation. Pro-conservation attitudes and beliefs do not always result in conservation behavior. Policy instruments are not always effective at improving indoor water conservation. 


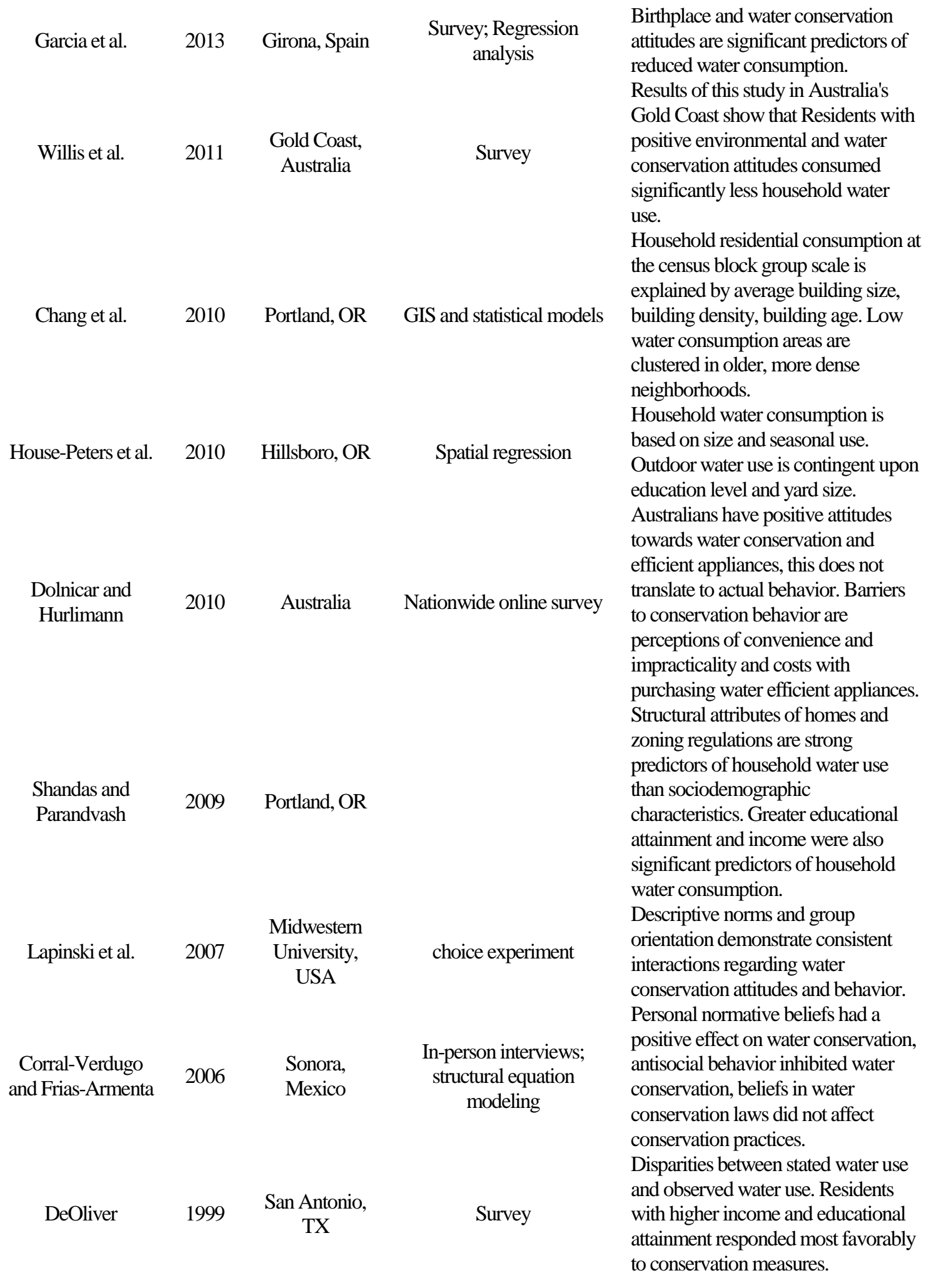




\section{Purpose and Research Questions}

The purpose of this research is to examine water customers' attitudes towards water conservation and what factors mediating their conservation beliefs ultimately result in water savings. Understanding customer water conservation attitudes and behaviors is critically important to water managers. We seek to determine if water customers exhibit pro-conservation attitudes, if stated pro-conservation attitudes map onto respondents empirically tested water consumption behavior, and what intermediary variables serve as good predictors of water consumption behavior. In addition, we are curious if perceived climate risks influence or promote pro-conservation behavior.

Research Questions:

1. Does perceived climate risk influence and strong pro water conservation attitudes result in increased water conservation?

2. Are the stated water conservation attitudes significant predictors of actual water consumption?

3. What are the significant intermediary variables linking water conservation attitudes to water conservation outcomes? 


\title{
Data and Methods
}

\author{
Study Area
}

The Clackamas Watershed is a multi-use watershed, water for agricultural irrigation, critical habitat for anadromous fish, hydroelectric power, and recreational opportunities. Most importantly, eight water districts draw from the Clackamas River to provide drinking water to over 300,000 people. The area is experiencing rapid population growth due largely to in-migration from outlying counties with the expectation of 107,000 new residents within the county by 2035 (Chun et al., 2018). The primary surface water withdrawal in the watershed is for irrigation (44.62 Million gallons/day), the second largest use is for household consumption (27.9 Million gallons/day) (Dieter et al. 2015). The large portion of water withdrawn for domestic uses coupled with increased population growth make residential consumption and ideal target for water conservation programs.

Three water districts (e.g. Clackamas River Water, Lake Oswego, and Sunrise Water Authority) in the region participated in this study. The Portland Metropolitan Area (PMA) is an intriguing case to test some of these theories given its increasing concern about climate change and water resource sustainability (Larson et al. 2013) along with its self-evident progressive environmental ideology (Straus et al., 2016) and rapid urban growth rate of 1.8\% per year (Portland, Oregon Population 2019,n.d.).

Data

Between March and June of 2016, a survey of Clackamas County, Oregon was conducted to gain insight into water customers' attitudes and behavior regarding climate change beliefs, water 
conservation, and watershed protection. Questionnaires were distributed to 1,200 randomly selected water ratepayers in March 2016. We received 405 completed questionnaires resulting in a 34\% response rate from our sample population. Average nonresponse rate to survey items was $20 \%$. Surveys were returned by mail or via an online survey instrument.

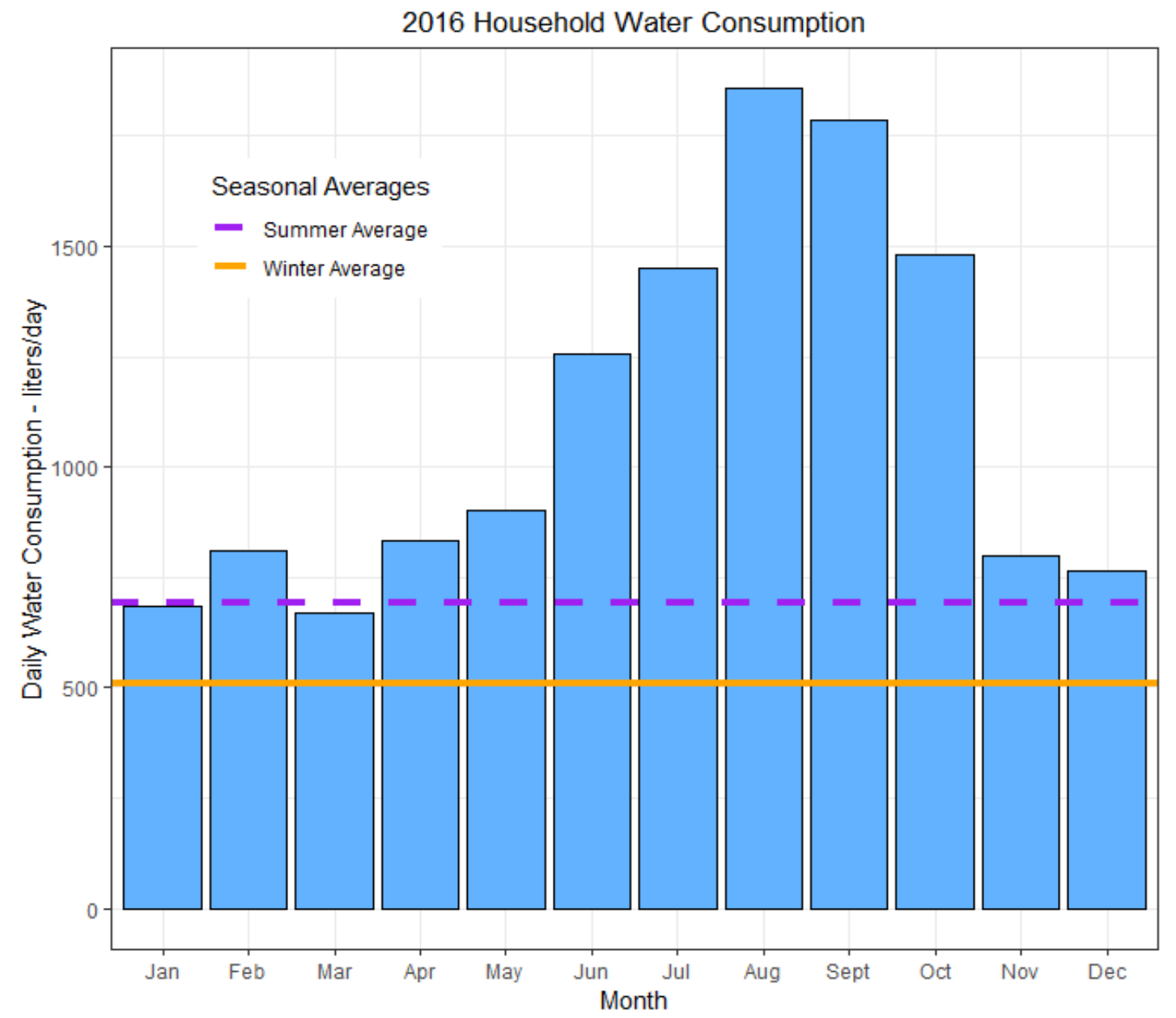

Figure 2-1. Average Household Water Consumption in three water districts of the Clackamas River watershed (liters/day, $\mathrm{n}=215$ )

Figure 2-1 is a depiction of respondents' household water consumption from Jan-Dec. 2016 depicted in liters/day. Our original survey was distributed from March-June 2016. It is important to discuss the context of recent weather as that may have some influence on water use behavior. 
During 2015, the year prior to the distribution of our questionnaire, the summer average

temperature was $23.3^{\circ} \mathrm{C}$. The mean temperature for the base period of record from 1938-2000 was $19.05^{\circ} \mathrm{C}$ indicating a $4.25^{\circ} \mathrm{C}$ departure from mean temperature in 2015 . In 2016 the summer mean temperature was $20.5^{\circ} \mathrm{C}$ with only a $1.45^{\circ} \mathrm{C}$ departure from mean temperature (NOAA, n.d.).

Variables

Table 2-2. Variables collected by survey $(n=405)$

\begin{tabular}{|l|l|}
\hline Survey Items & Scale \\
\hline Income & Nine \$25,000 bins \\
\hline Age & Numeric entry \\
\hline Education Level & Less than High School Degree (1) to Graduate or Professional Degree (6) \\
\hline Political Leanings & 5-point Likert scale ranging from Very Conservative to Very Liberal \\
\hline Water Conservation Attitudes & 5-point Likert scale ranging from Strongly Agree to Strongly Disagree \\
\hline Lawn Care Attitudes & 5-point Likert scale ranging from Strongly Agree to Strongly Disagree \\
\hline Lawn watering frequency & $\begin{array}{l}\text { Less than once a month=0, Once or twice a month=1, Once a week=2, Two to three } \\
\text { times a week=3, Every other day=4, Every day=5 }\end{array}$ \\
\hline $\begin{array}{l}\text { PNW Climate Impact } \\
\text { Attitudes }\end{array}$ & 5-point Likert scale ranging from Strongly Agree to Strongly Disagree \\
\hline Property Size* & Square Meters \\
\hline Water Savings** & Negative of summer water consumption 2016 \\
\hline
\end{tabular}

*Based on tax assessed data; ** based on water consumption data provided by the water provider

Our analysis considered sociodemographic variables (Table 2-2) such as age, income, and political attitudes. We chose these sociodemographic indicators to compare to Clackamas County 2010 US Census and 2011-2015 American Community Survey to determine if our sample is representative of the population. Income was measured by asking respondent how much income they made after taxes in 2014 . Income ranged in bins beginning at $\$ 25,000$ to greater than $\$ 200,000$ in $\$ 25,000$ bins. The log value of the midpoint of each bin with a pareto-tail adjustment was used to correct for extreme values in the unbounded high income bin (Nielsen-Pincus et al., 2017). 
The water conservation portion of the survey contained five questions where survey respondents were asked to characterize their water use behavior: 1) The presence of a yard that requires watering, 2) Frequency of outdoor yard watering, 3) Type of watering systems, 4) Attitudes towards water conservation, and 5) Attitudes towards yard and lawn maintenance. Water conservation questions were scored on a 5-point Likert scale.

The pro conservation variable was derived by the mean agreement of the attitudes towards water conservation items (Table 2-2). This variable is an amalgamation of attitudinal dimensions of water conservation ranging from agreement with the phrase "I think about water conservation daily" to "If I knew my neighbors were involved in a water conservation program, I would be more likely to participate". This variable was created based upon similar pro water conservation items present in a household water conservation survey conducted in Portland, OR (Straus et al., 2016). The pro-water conservation variable utilized in this study (Table 3) was constructed by questions that address both social normative beliefs and personal norms. Beliefs regarding Pacific Northwest Climate were assessed using a four-item scale. The four-item scale was reduced to a single variable by taking the mean of the four items to produce a Pacific Northwest Climate Beliefs Index (Table 2-2).

Property size was derived by through the Metro Regional Land Information System (RLIS) taxlot dataset. Parcel size was converted from acres to square meters. Household water consumption data was provided by the three participating water districts for survey respondents $(\mathrm{n}=$ 215). Household water consumption data was obtained for 2016 , the year when the survey was distributed. Seasonal consumption patterns between summer (July and August) and winter (January and February) were analyzed to determine the difference between winter, which can be viewed as 
base consumption, to summer. Water savings/water conservation was determined by subtracting winter water consumption from summer consumption. This value was then assigned a negative sign and termed water savings. The approach for determining water savings was adapted from a similar water conservation study conducted in Portland, Oregon (Straus et al., 2016). Only two months were selected for summer and winter due to data availability. Both property size and water savings were scaled for analysis by dividing the original values by 1000 . This was done to control for scale imbalances within the model.

Table 2-3. Descriptive statistics of analysis variables

\begin{tabular}{|c|c|c|c|c|}
\hline Variables & $\mathrm{N}$ & Mean & SD & Median \\
\hline Pacific Northwest Climate Index ${ }^{a}$ & 183 & 2.8 & 0.83 & 3 \\
\hline Winters are becoming warmer & 183 & 2.96 & 0.86 & 3 \\
\hline Winters are becoming shorter & 182 & 2.72 & 0.95 & 3 \\
\hline Summers are becoming drier & 182 & 2.9 & 0.94 & 3 \\
\hline Summers are becoming longer & 182 & 2.69 & 1.02 & 3 \\
\hline Pro Water Conservation Attitudes ${ }^{\mathrm{a}}$ & 184 & 2.53 & 0.77 & 2.5 \\
\hline $\begin{array}{l}\text { I think about water conservation daily } \\
\text { I understand my community may have to implement more }\end{array}$ & 179 & 2.16 & 1.13 & 2 \\
\hline & 184 & 2.83 & 1.01 & 3 \\
\hline & 184 & 2.81 & 0.95 & 3 \\
\hline program, I would be more likely to participate & 182 & 2.4 & 1 & 2 \\
\hline $\begin{array}{l}\text { Water Saving Devices } \\
\text { Imake sure to install water saving devices in my house (e.g., low } \\
\text { flow showerheads and faucets) }\end{array}$ & 184 & 2.99 & 0.91 & 3 \\
\hline $\begin{array}{l}\text { Water Conservation Appliances }{ }^{\mathrm{b}} \\
\text { I have purchased water efficient appliances for my home (e.g., } \\
\text { dishwasher, washing machine, toilets) }\end{array}$ & 183 & 3.16 & 0.84 & 3 \\
\hline Lawn watering frequency & 193 & 3.15 & 1.21 & 3 \\
\hline Plants native plants ${ }^{\mathrm{b}}$ & 183 & 1.2 & 1.14 & 1 \\
\hline Plants drought tolerant plants ${ }^{\mathrm{b}}$ & 183 & 2.26 & 1.06 & 2 \\
\hline Property Size $\left(m^{2}\right)$ & 215 & 1249.13 & 1036.14 & 929.1 \\
\hline Water Savings (liters/day) & 215 & 180.62 & 756.95 & 130.05 \\
\hline
\end{tabular}




\begin{tabular}{llllll} 
Age & 198 & \multicolumn{2}{c}{59.69} & 14.45 & \multicolumn{1}{c}{60} \\
Education & 200 & Bachelor & NA & Bachelor \\
& & Somewhat & & Somewhat \\
Political Attitudes & 202 & Liberal & NA & Liberal \\
Income & 181 & $75 \mathrm{k}-99 \mathrm{k}$ & NA & $75 \mathrm{k}-99 \mathrm{k}$ \\
\hline
\end{tabular}

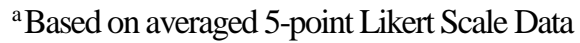

${ }^{\mathrm{b}}$ Based on 5-point Likert Scale Data

${ }^{\mathrm{c}}$ Binary (Yes or No)

\section{Data Analysis}

The first phase of the analysis will involve a summary univariate description of respondent's water conservation attitudes and socio-demographic characteristics. Respondent characteristics are compared to Clackamas County 2010 US Census and 2011-2015 American Community Survey Demographic data to assess the representativeness of our sample.

The next phase of analysis will involves examining parametric Pearson's $r$ bivariate correlations of common predictors of water consumption (e.g. property size, income, education, political affiliation, pro-conservation attitudes, and climate change beliefs), and empirically derived water consumption data. The correlation between pro-conservation attitudes and waterconsumption will be controlled for by property size (Straus et al., 2016). A correlation matrix was constructed and visualized in a correlation plot (Figure 2-2). Variables with positive correlations are highlighted in blue with the darker shade indicating the strength of the correlation. Variables with a negative correlation are shaded in red. All insignificant correlations $(\mathrm{p}>0.01)$ were omitted from the correlation matrix.

A path analysis was employed to explore the sequential relationships between water conservation attitudes, climate change attitudes, stated water conservation behaviors, and 
empirically derived water consumption data. Path models are often used to explore patterns of causality between a set of variables. An important condition of this causality is that covariation between $\mathrm{X}$ and $\mathrm{Y}$ should not disappear when prior variables with a logical sequence are added to the system. This method is not designed to deduce causal relationships from the values of correlation coefficients, but to provide a quantitative assessment of relationships that are known to hold and separate direct from indirect effects (Guhathakurta \& Gober, 2010). We focus our path analysis on the impact of stronger pro-conservation and climate impact attitudes in the survey, and how corresponding behaviors contribute or predict water conservation behavior. Building upon previous research from Straus et al. (2016) our hypothesized path relationships follow a directional pattern of attitudes, behaviors, and resulting reduced seasonal water variation when controlling for property size. We explored multiple path model specifications which will be discussed in the Results section. We chose path analysis in favor of structural equation modeling (SEM) as we were only interested in observed variables, not latent variables. In addition, we wanted to explore the mediating effects between attitudes and conservation outcomes. All path analyses were conducted in R Studio version 3.3.2 using the Lavaan statistical package for latent variable modeling (Rosseel, 2010). The outputs from our path analysis are displayed in (Table 2-4). In order to create a parsimonious and just identified model, the variable Water saving devices was omitted from the final round of modeling. The Comparative Fit Index (CFI) and Tucker Lewis Index (TLI) are widely accepted statistical fit measures that are designed to assess the improvement of model fit over a baseline model with no relationship among the variables (S. Wang \& Gita Taasoobshirazi, 2016). 


\section{Results}

\section{Summary Statistics}

Our univariate analysis of sociodemographic variables and other predictors yielded results that are reasonably representative of Clackamas County residents. Survey respondents were generally middle-aged with a median age of 59, college educated (bachelor's degree), homeowners. Our survey respondents' median age is higher than the US Census American Community Survey Profile (2013-2017) reported median age of 41 years for Clackamas County. However, our respondents are water ratepayers that own their homes, and not an entire representation of Clackamas County residents. Home owners within Clackamas County over the age of 55 comprise $55 \%$ of the population. Compared to median age of survey respondents, it appears that older homeowners are representative of more than half of the population. Approximately $59 \%$ of respondents possessed a bachelor's degree or higher. This is slightly higher than the Clackamas County average of homeowners with a bachelor's degree or higher (43\%). A predisposition of more educated participants is a common trend in survey research. Some explanations for higher educational attainment in our sample are that our respondents were more likely to be homeowners and heads of household, both of which are associated with increased educational attainment (Segal \& Sullivan, 1998). The primary income bracket for respondents was between $\$ 75,000$ to $\$ 99,000$, median household income for homeowners in Clackamas County is $\$ 72,408$. Considering median age of our respondents is 59, homeowners in Clackamas County between the ages of 45 to 64 have a median household income of $\$ 87,689$. Our respondents were skewed towards liberal political 
leanings with $44 \%$ liberal, $28 \%$ reporting conservative leanings, and $28 \%$ identifying as neither liberal or conservative. This differs slightly from 2014 Clackamas County voter registration with 36\% Democrat, 31\% Republican, and 33\% Other. We make the assumption that party affiliation with Democrat equates to Liberal and Republican to Conservative.

Respondents exhibited agreement that climate in the PNW was changing $(\mathrm{M}=2.8, \mathrm{SD}=$ $0.83)$ and similar attitudes towards being pro water conservation $(\mathrm{M}=2.53, \mathrm{SD}=0.77)$. In addition to having positive climate change and pro water conservation beliefs, respondents also demonstrated agreement with the notion of installing water saving devices and purchasing water efficient appliances for their homes. Most respondents had lawns, which required watering and exhibited and average watering schedule of 2-3 per week. The composition of respondent's yard vegetation exhibited less agreement than the aforementioned variables with respondents somewhat disagreeing with planting native plants in their yard $(\mathrm{M}=1.2, \mathrm{SD}=1.14)$ and indifference to planting drought tolerant plants $(M=2.26, S D=1.06)$. Mean property size $(M=1249.13)$ is roughly equivalent to a quarter acre parcel, which is not surprising given the general suburban makeup of the sample. Mean water savings was positive $(M=180.62, \mathrm{SD}=756.95)$ with some notable variation therein (Table 2-3).

Exploratory Correlations 


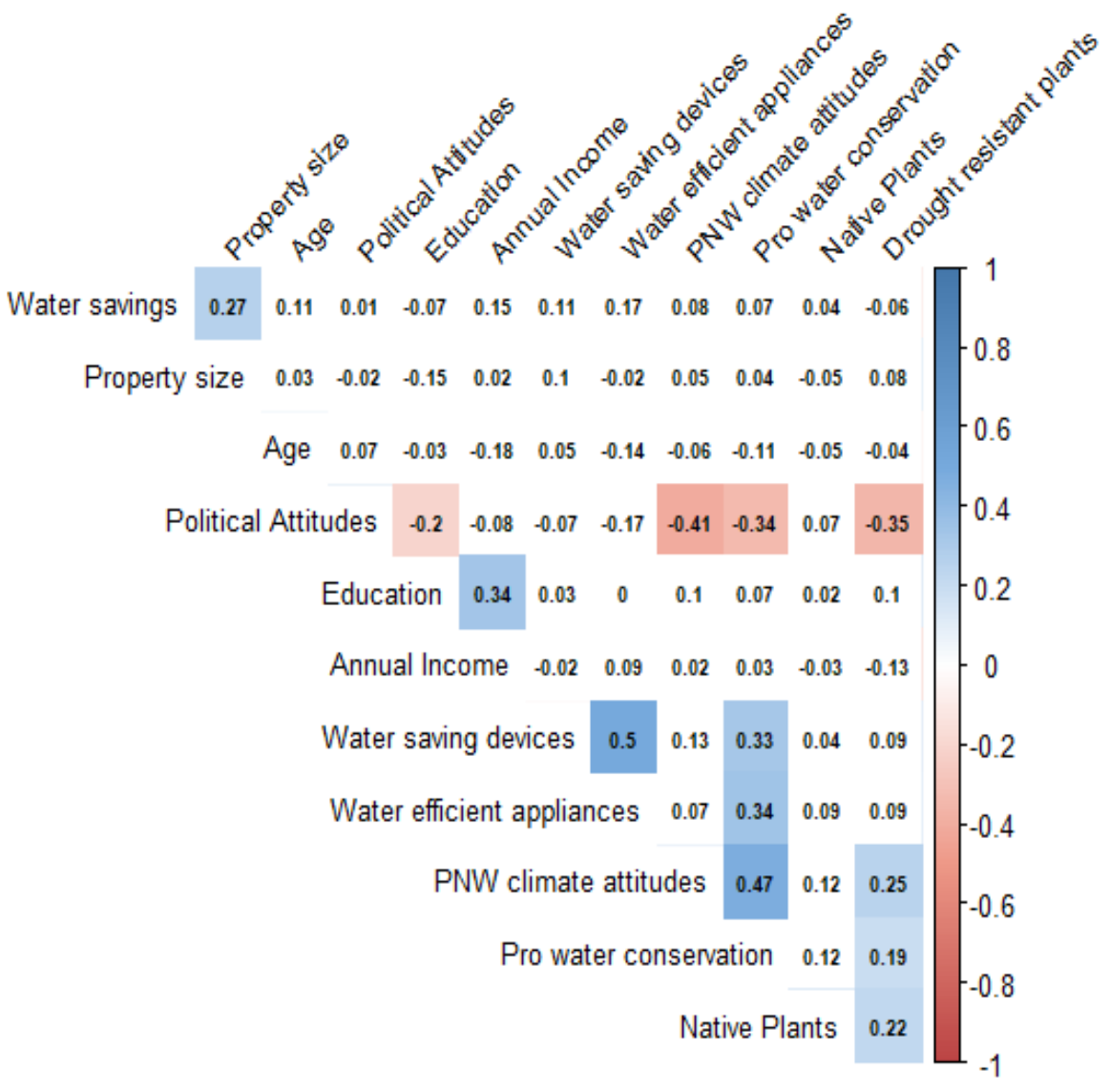

Figure 2-2. Correlation Matrix of Analysis Variables

The result of plotting the correlation matrix produced interesting results. The most prominent result being that PNW climate attitudes and Pro water conservation attitudes were not statistically significantly correlated to water savings. Not surprisingly, water savings is weakly positively associated with property size $(r=0.27, \mathrm{p}<0.01)$, while the strongest positive correlation existing between the presence of water saving devices and water efficient appliances in the home ( $\mathrm{r}$ $=0.5, \mathrm{p}<0.01)$. Which is logically consistent since respondents interested in conserving water are likely to pursue multiple methods for doing so. A moderate correlation emerged between Pro water conservation and water saving devices and water efficient appliances $(r=0.33, p<0.01 ; r=0.34, p$ $<0.01$ ), respectively. Interestingly, a strong correlation between PNW climate attitudes and Pro 
water conservation also exists $(r=0.47, \mathrm{p}<0.01)$, suggesting that respondents with strong water conservation attitudes may also feel strongly about climate change impacts. In addition, there is also a weak correlation between PNW climate attitudes, Pro water conservation beliefs, and planting native plants with the presence of drought resistant plants $(\mathrm{r}=0.25, \mathrm{p}<0.01 ; \mathrm{r}=0.19, \mathrm{p}<0.01 ; \mathrm{r}=$ $0.22, \mathrm{p}<0.01)$, respectively. Not surprisingly, there are strong negative correlations between Political Attitudes and PNW climate attitudes, Pro water conservation, and planting drought resistant plants $(\mathrm{r}=-0.41, \mathrm{p}<0.01 ; \mathrm{r}=-0.34, \mathrm{p}<0.01 ; \mathrm{r}=-0.35, \mathrm{p}<0.01)$, respectively.

Ultimately, the correlation matrix (Figure 2-2) illustrates a general profile of the types of water customers in our sample. The political attitudes variable was scaled from "Very Liberal" to "Very Conservative" indicating as a respondent identifies as more conservative, there is a negative correlation with education, PNW climate attitudes, pro water conservation attitudes, and the planting of drought resistant plants $(\mathrm{r}=-0.20, \mathrm{p}<0.01 ; \mathrm{r}=-0.41, \mathrm{p}<0.01 ; \mathrm{r}=-0.34, \mathrm{p}<0.01 ; \mathrm{r}=-$ $0.35, \mathrm{p}<0.01)$, respectively. Since our sample is predominantly liberal, respondents with liberal leanings espouse stronger PNW climate attitudes, pro conservation attitudes, and the planting of drought resistant plants.

Path Analysis

Table 2-4. Attitudes - Behavior - Water Savings Path Analysis Model Fit Indices

\begin{tabular}{|c|c|c|c|}
\hline \multicolumn{4}{|l|}{ Model Fit Indices } \\
\hline Global Fit Indices & & R-Square: & \\
\hline $\begin{array}{l}\text { Comparative Fit } \\
\text { Index CFI }\end{array}$ & 0.934 & $\begin{array}{l}\text { Estimate } \\
\text { Water }\end{array}$ & \\
\hline $\begin{array}{l}\text { Tucker-Lewis Index } \\
\text { (TLI) }\end{array}$ & 0.868 & $\begin{array}{l}\text { Savings } \\
\text { Scale }\end{array}$ & 0.156 \\
\hline
\end{tabular}




\begin{tabular}{|c|c|c|c|c|c|}
\hline $\begin{array}{l}\text { Root Mean Square } \\
\text { Error of } \\
\text { Approximation } \\
\text { (RMSEA) }\end{array}$ & 0.055 & & $\begin{array}{l}\text { Water } \\
\text { Efficient } \\
\text { Appliances }\end{array}$ & 0.031 & \\
\hline \multirow[t]{2}{*}{$\begin{array}{l}\text { Standardized Root } \\
\text { Mean Square } \\
\text { Residual (SRMR) }\end{array}$} & \multirow[t]{2}{*}{0.056} & & $\begin{array}{l}\text { Drought } \\
\text { Resistant } \\
\text { Plants }\end{array}$ & \multicolumn{2}{|l|}{0.098} \\
\hline & & & $\begin{array}{l}\text { Native Plants } \\
\text { Lawn } \\
\text { Watering } \\
\text { Frequency }\end{array}$ & \multicolumn{2}{|l|}{0.003} \\
\hline Paths & Estimate & Std.Err & z-value & $\mathrm{P}(>|\mathrm{z}|)$ & Std.all \\
\hline \multicolumn{6}{|l|}{$\begin{array}{l}\text { Seasonal Water } \\
\text { Variation Scale }\end{array}$} \\
\hline Property size scale & 0.243 & 0.054 & 4.499 & 0.000 & 0.318 \\
\hline Native Plants & 0.040 & 0.050 & 0.801 & 0.423 & 0.057 \\
\hline $\begin{array}{l}\text { Drought Resistant } \\
\text { Plants }\end{array}$ & -0.096 & 0.053 & -1.806 & 0.071 & -0.128 \\
\hline $\begin{array}{l}\text { Water Efficient } \\
\text { Appliances }\end{array}$ & 0.183 & 0.068 & 2.707 & 0.007 & 0.192 \\
\hline $\begin{array}{l}\text { Lawn Watering } \\
\text { Frequency }\end{array}$ & 0.023 & 0.048 & 0.477 & 0.634 & 0.034 \\
\hline \multicolumn{6}{|l|}{ Native Plants } \\
\hline $\begin{array}{l}\text { Pro water } \\
\text { conservation }\end{array}$ & 0.137 & 0.126 & 1.085 & 0.278 & 0.092 \\
\hline $\begin{array}{l}\text { PNW climate } \\
\text { attitudes }\end{array}$ & 0.164 & 0.120 & 1.366 & 0.172 & 0.116 \\
\hline \multicolumn{6}{|l|}{$\begin{array}{l}\text { Drought Resistant } \\
\text { Plants }\end{array}$} \\
\hline $\begin{array}{l}\text { Pro water } \\
\text { conservation }\end{array}$ & 0.153 & 0.114 & 1.343 & 0.179 & 0.110 \\
\hline $\begin{array}{l}\text { PNW climate } \\
\text { attitudes }\end{array}$ & 0.328 & 0.108 & 3.028 & 0.002 & 0.248 \\
\hline \multicolumn{6}{|l|}{$\begin{array}{l}\text { Water Efficient } \\
\text { Appliances }\end{array}$} \\
\hline $\begin{array}{l}\text { Pro water } \\
\text { conservation }\end{array}$ & 0.456 & 0.088 & 5.207 & 0.000 & 0.416 \\
\hline $\begin{array}{l}\text { PNW climate } \\
\text { attitudes }\end{array}$ & -0.148 & 0.083 & -1.77 & 0.077 & -0.141 \\
\hline \multicolumn{6}{|l|}{$\begin{array}{l}\text { Lawn Watering } \\
\text { Frequency }\end{array}$} \\
\hline $\begin{array}{l}\text { Pro water } \\
\text { conservation }\end{array}$ & 0.021 & 0.133 & 0.16 & 0.873 & 0.014 \\
\hline $\begin{array}{l}\text { PNW climate } \\
\text { attitudes }\end{array}$ & -0.091 & 0.127 & -0.719 & 0.472 & -0.062 \\
\hline
\end{tabular}


We explored multiple model specifications before ultimately choosing the most parsimonious version that yielded acceptable global model fit results. Previous models included the variable water saving devices and possessed a non-directional (correlation) relationship between PNW climate attitudes and Pro water conservation. As shown in Figure 2-2, because there was a strong correlation between water efficient appliances and water saving devices $(r=0.50)$, we removed water saving devices from the model to improve model fit. In addition, there was a strong correlation between PNW climate attitudes and Pro water conservation $(r=0.47)$. Therefore, the paths between the two attitudinal variables was designated non-directional to account for this correlation. Examination of previous model results yielded a poor fit with $(\mathrm{CFI}=0.633, \mathrm{TLI}=$ 0.462). The final model specification produced a stronger model fit. According to our global fit indices CFI and TLI, our final model is close to the cutoff threshold for adequate (CFI $=0.934$, TLI $=0.868$, respectively. The CFI and TLI in practice should have cutoff values close to 0.95 . Our Root Mean Square Error of Approximation (RMSEA) is acceptable according to Hu and Bentler (1999) with $($ RMSEA $=0.055)$ and an acceptable cutoff threshold of 0.06, and. These conditions must be satisfied in order to conclude a reasonably good fit between the specified model and observed data (Hu \& Bentler, 1999).

Inspection of the highlighted p-values for the significant paths (Table 2-4) yields interesting results. Very few of the paths in the model were significant. Property size $(\beta=0.243, p<0.05)$, presence of water efficient appliances $(\beta=0.183, p<0.05)$, PNW climate attitudes $(\beta=0.328, p$ $<0.05)$, and pro water conservation attitudes $(\beta=0.456, p<0.05)$ emerged as the only significant paths within the model. The magnitude of the pro conservation and PNW climate attitude paths stand to support our original hypothesis that strong pro conservation and PNW climate attitudes will 
result in water conservation outcomes. It is important to note that both property size and water savings were scaled for analysis e.g. (water savings/1000). Multiplying the model estimates for both property size and water savings aids in a better conceptual understanding of the results. A 1,000 square meter increase in property size results in an estimated 243 liters/day increase of seasonal water variation. The use of water efficient appliances in the home resulted in increased seasonal water variation. A one unit increase in the water efficient appliances scale yields a predicted increase of 183 liters/day in seasonal water variation per household. Our two hypothesized variables of interest, pro water conservation attitudes and PNW climate change beliefs, also resulted in a predictive behavioral outcome. A one unit increase in PNW climate change beliefs resulted in 0.328 increase in the presence of drought resistant plants in a respondents' yard. A one unit increase in the pro water conservation scale produced a 0.456 increase in the presence of water efficient appliances in the home. The visual representation of the path model below depicts the models and standardized coefficients of their respective paths (Figure 3-3). 


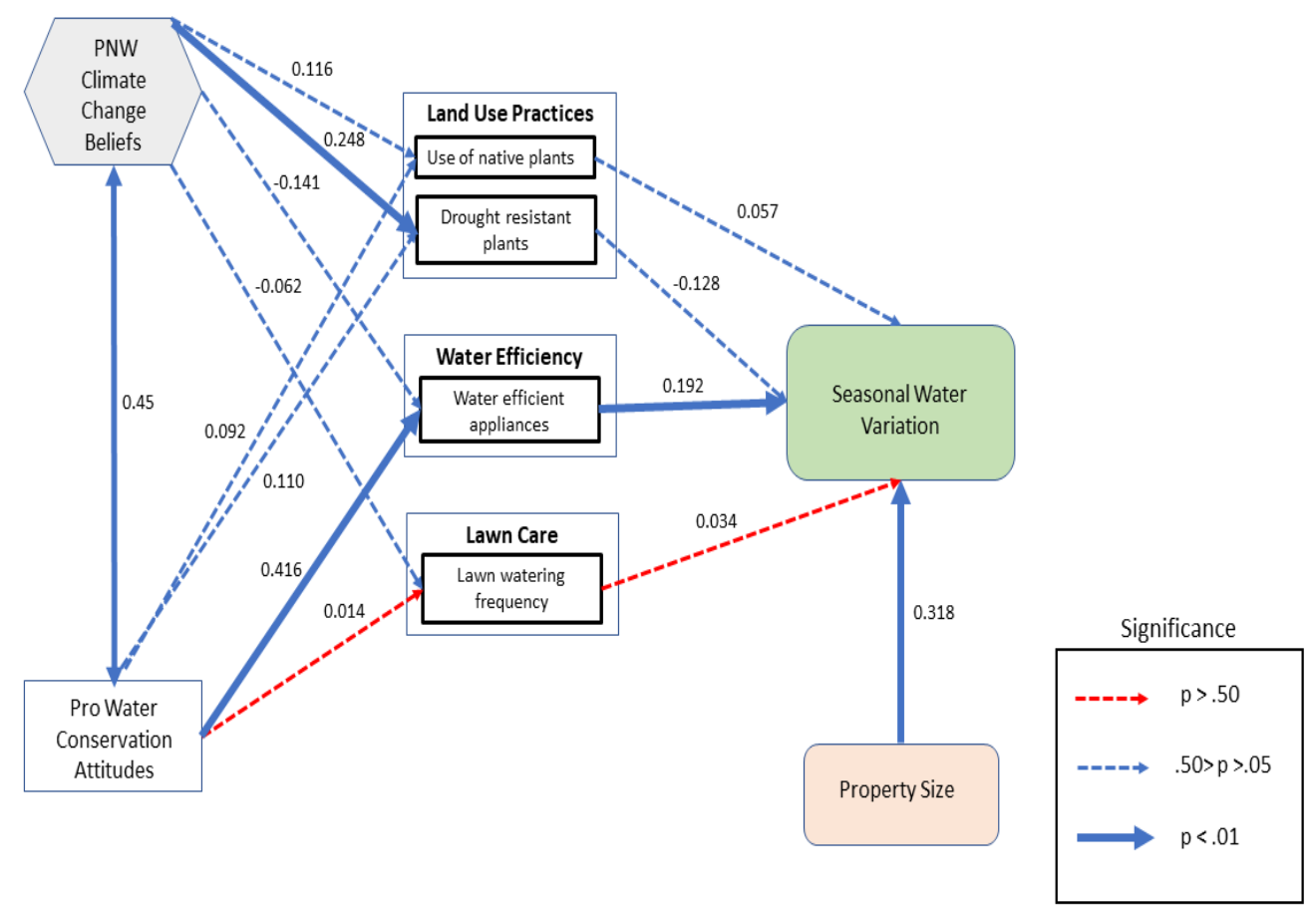

Figure 2-3. Path model depicting variables and standardized coefficients ( $\beta$ ).

It is important to note that while pro water conservation attitudes and PNW climate change beliefs were both significant predictors of selected intermediary variables (e.g. drought resistant plants and water efficient appliances), only pro water conservation attitudes and its path to water efficient appliances produced a significant path resulting in increased seasonal water variation. Property size was the only other significant predictor of seasonal water variation.

\section{Discussion and Conclusion}

Population increase and the deleterious effects of climate change have produced inequities between the supply and demand of freshwater around the globe (B. S. Jorgensen et al., 2014). Declining supplies of fresh water have prompted policy-makers to implement various demand management strategies designed to reduce household water consumption to alleviate demand 
during peak periods of consumption (Willis et al., 2011a). Understanding attitudes towards household water consumption and how these attitudes result in an increase or decrease in water savings is of paramount importance to policy-makers interested in the longevity and resilience of their water supply system.

The purpose of this research was to examine water customers' attitudes towards water conservation and climate change, and what behaviors mediating their attitudes resulted in reduced seasonal water variation. We were curious if these behaviors served as good predictors of seasonal water variation and if strong conservation and climate change beliefs ultimately result in seasonal water variation. Our results show that strong climate beliefs and pro water conservation attitudes together were not significant predictors of water conservation. Climate attitudes were a significant predictor for the presence of drought resistant plantings. However, this path did not ultimately result in water savings. Alternatively, strong pro conservation attitudes did ultimately result in increased seasonal water variation with water efficient appliances serving as an intermediary variable.

Our findings support the claims of previous research stressing the importance of attitudes on promoting pro-conservation behavior. While attitudes are important, there are other factors influencing water consumption behavior. Previous research has found that pro-water conservation attitudes are a good predictor of reduced household water consumption (Lowe et al., 2015; Laura A. Warner et al., 2018; Willis et al., 2011a). Willis et al. (2011) found that strong pro-water conservation beliefs could result in an 18-53\% reduction in household water use. However, our path model demonstrated that strong pro-water conservation beliefs, the presence of water efficient appliances result in an increase of 183 liters/day in water seasonal water variation. Attitudes can serve as important predictors of reduced consumption but intermediary behaviors must also be 
taken into account. The finding that strong conservation attitudes and the presence of water efficient appliances produce an increase in seasonal water variation may seem counterintuitive. The increased consumption with the presence of water efficient appliances can be explained by the Jevon's Paradox which posits that energy (or water) efficiency gains in household appliances tend to increase overall consumption, which is contrary to the stance of many environmentalists, policy makers, and NGO's (Alcott, 2005).

This chain of attitudes and behaviors provides keen insight for water managers interested in educating their customers about water savings. Our results differ slightly from the path analysis conducted by Straus et al. (2016), which found that pro-conservation attitudes and significant water savings were mediated by the presence of native plants in landscaping. We did not find native plants to be a significant mediator in our causal chain when controlling for property size. Results from the path model also substantiate previous findings (Chang et al., 2010; L. House-Peters et al., 2010; Straus et al., 2016) that property size is a significant predictor of water consumption. Straus et al. (2016) examined water recycling and the presence of low flow technology within the household, which are similar to water efficient appliances however those variables were not significant in mediating conservation attitudes and water savings. Our results refute the findings of CorralVerdugo \& Armenta (2006), which found that social normative beliefs (e.g. understanding the behaviors of others) and personal norms (e.g. feeling of obligation to act in a certain manner) where significant in predicting water conservation behavior.

Attitudes merit further discussion because they present a softer approach to "harder" demand management strategies such as curtailment, taxes, or increased fee structures during periods 
of peak demand. Attitudes are subject to influence through a variety of outreach and education campaigns that can target various audience segments.

We sought to build on previous research investigating the connection between climate change attitudes and water conservation behavior (Brownlee et al., 2014). The primary difference between the aforementioned study and our own is the socio-ecological context of the study area in question. The South Carolina, US study was predicated on respondents' knowledge of a recent drought and its local-level impacts. Given the verdant landscapes an abundant rainfall in the PNW, perhaps respondents' beliefs in climate change were not of the magnitude to prompt water conservation behaviors.

The intermediary variables present in our path model and their significant influence on seasonal water variation also represent an opportune entry point for policy makers interested in reducing water consumption. Fostering a strong pro conservation and strong climate change impact attitude structure may be challenging from a policy-maker perspective. Hypothetically, water providers may initiate a rebate program for the installation of EPA Water Sense or Energy Star high efficiency toilets and washing machines with either direct compensation for the appliance or a fee reduction in subsequent utility bills. A similar program was piloted in Miami-Dade County, Florida over the span of four years. The program resulted in approximately a 6-14\% reduction in water consumption for the first two years of the study with water savings continuing at lower levels during the remainder of the study period (Lee, Tansel, \& Balbin, 2011).

The adoption of water specific devices does not necessarily result in direct reductions in consumption as our research and previous studies have shown (Fielding, Russell, Spinks, \& Mankad, 2012). It has the potential to result in increased water use as the perception of efficient 
devices prompts higher than previous consumption known as offsetting behavior. The most effective programs are those that are administered on a one-on-one basis to individual households because they foster a sense of cooperation. This approach may have a smaller overall impact, but a greater impact per household. These approaches coupled with broad-based continual education campaigns aimed at different audiences such as children and households has the greatest chance of maximizing the effectiveness of a water conservation program (Campbell, Johnson, \& Larson, 2004).

Ultimately, a successful water conservation campaign will be a mixed mosaic of water conservation devices within each household, and education programs designed to educate water customers in best practices of water savings. Policy makers and water managers would do well to cultivate a culture of water conservation amongst water customers. Conservation goals can be achieved through individual one-on-one appliance replacement programs which foster cooperation, school education programs discussing the benefits and methods of water savings, and broader public education programs. This mixed-mosaic approach must be continually evaluated and modified to fit the unique socio-ecological context of a given area. Despite its seeming abundance in some regions, water is a finite and pristine resource, and the onus of responsibility is on water consumers and providers to take substantive actions to ensure its continued quality and provision. 
Chapter 3: Clackamas Water Customer Types: What are they and what is their distribution?

\begin{abstract}
Managing residential water demand and protecting source watersheds are critical tasks for water managers as freshwater resources are increasingly threatened by adverse climate impacts and population growth. We conducted a segmentation analysis based on survey data of water customers $(n=405)$, focusing on attitudinal variables such as water conservation, climate impacts, trust, and sense of place. We identified two distinct customer types with distinct separation around climate and water conservation attitudes. We mapped water customer types onto survey respondents' locations to determine if there were any spatial patterns in attitudinal clustering. Customer types exhibiting more positive water conservation attitudes and strong attitudes regarding climate impacts clustered highly in more affluent urbanized portions of the study area, while the customer type with negative water conservation and climate attitudes clustered higher in more rural and working-class neighborhoods. Understanding attitudes of water customers, how they can be segmented, and where specific segments exist are useful tools for water managers interested in piloting social marketing campaigns aimed at promoting water conservation and protection.
\end{abstract}

Keywords: Water conservation, Climate change, Audience Segmentation, Cluster analysis

\title{
Introduction
}

Within the last fifty years, the global population has made a massive relocation to cities. This massive growth coupled with the disrupting effects of climate change on water supply and sanitation systems places water resources in a precarious position. Policy-makers are increasingly concerned with securing future water sources and managing water demand. In the face of these 
challenges, sustainability of fresh water resources are an increasing concern in many regions of the world and have prompted initiatives designed to conserve water (Heejun Chang, Bonnette, Stoker, Crow-Miller, \& Wentz, 2017; Ibrahim, Knox, Rundle-Thiele, \& Arli, 2018; Lede \& Meleady, 2019; Lowe, B., Lynch, D., \& Lowe, 2014; X. J. Wang et al., 2018; Laura Anne Warner et al., 2017). The United States has seen an increase in water conservation outcomes as a result of regulatory policy initiatives, improvements in water efficiency technology, densification of urban areas, and targeted social marketing campaigns e.g. "Turn off the Tap" (Brelsford \& Abbott, 2017; Heejun Chang et al., 2017; Ghavidelfar, Shamseldin, \& Melville, 2017; Straus et al., 2016).

The previous chapters have discussed water customer attitudes towards watershed protection and water conservation. It is of primary interest to researchers and watershed managers to understand if these attitudes translate into pro-environmental behavior, and if they are subject to behavioral influence. The introductory section of the paper will provide a conceptual overview of the following themes as they relate to our research design: 1) Review of social influence approaches and techniques known as social marketing; 2) Explore the subdiscipline of Community-Based Social Marketing (CBSM) with relevant case studies; 3) Common approaches to audience segmentation in social marketing; and 4) Methods for analyzing the spatial distribution of audience segments.

Social Marketing (SM)

Promoting the continued growth of watershed protection and conservation efforts in urbanizing watersheds will require tools from the social marketing (SM). Social marketing (Table 3-1) uses commercial marketing techniques to promote an idea or behavior that benefits and individual or society (Monroe, 2003). Social marketing relies on techniques that target specific 
behaviors that may be described by the Theory of Planned Behavior (Ajzen, 1991). This approach to public outreach has been commonly used in the public health to promote proactive health diagnostic examinations and has been employed by environmental organizations (Monroe, 2003). Social marketing implemented in the early stages of the policy process can better communicate policy goals while promoting the adoption of environmental policies (Altman \& Petkus, 1994). Research shows that coupling behavioral analysis and social marketing, while emphasizing a "systems thinking" lens can increase the efficacy of behavior change programs (Domegan et al., 2016; Geller, 1989). Social marketing techniques have been utilized in watershed protection, water conservation, and climate change awareness campaigns in a variety of settings ranging from national water conservation programs in Australia (Dolnicar \& Hurlimann, 2010), to local awareness of climate impacts in rural farm villages in Punjab, India (Sharma, Kaur, Mittal, Kaur, \& Kaur, 2018).

Social influence and behavioral change campaigns are optimal approaches for water demand management (WDM) as they are cost effective, easy to implement, and result in significant water use reductions (Lede \& Meleady, 2019). Information-based water conservation campaigns are theoretically formulated to correct a knowledge-deficit, implying that if customers knew how to save water more effectively this would lead to reduced water consumption, however the success of these programs is limited (Seyranian et al., 2015; Syme, Nancarrow, \& Seligman, 2000). A casestudy in Los Angeles, California sought to explore the framing of four intervention approach for a water conservation program using knowledge deficit, social norms (e.g. appropriate behavior relative to the group), personal identity (e.g. individual), and social identity (e.g. collective). Researchers found that respondents which received knowledge deficit interventions used more 
water than other intervention strategies (Seyranian et al., 2015). These findings were supported by Landon et al. (2019) in a survey and behavioral intervention study of outdoor water users in College Station, Texas. Water use increased among the lowest consuming households that received information-based messaging compared to households that which received social normative messaging. Water conservation campaigns can be better designed and implemented if policy makers understand how individuals respond to normative messaging, while understanding how messages are framed and the potential for unanticipated side-effects (Landon, Woodward, Kyle, \& Kaiser, 2018). A social marketing study conducted in southeastern Australia found that perceived behavioral control was a significant predictor of behavioral intent, and attitudes have the greatest effect upon intentions to save water. Key factors were respondents' attitudinal changes to water use, and feelings that their water provider are managing resources effectively, this campaign resulted in a reduction in daily water consumption by 150 liters/person (Lowe, B., Lynch, D., \& Lowe, 2014; Lowe et al., 2015).

\section{Community Based Social Marketing (CBSM)}

Community Based Social Marketing is similar to SM; however, an increased emphasis is placed on local action and stakeholder engagement in the process. The CBSM approach (Table 3-1) is comprised of: 1) identifying barriers to behavior; 2) Selecting optimal behaviors; 3) Designing programs to overcome barriers to specific behavior; 4) Piloting a behavior change program; and 5) Evaluating program effectiveness (Mckenzie-Mohr, 2000; Myers, 2016). The city of Durham, Ontario was faced with the need to construct a costly new water treatment plant to meet the city's growing water supply needs. A CBSM program was implemented with the goal of reducing water consumption by $10 \%$. Effective interventions resulted in a $66 \%$ reduction in water use by the 
experimental group. A similar study was piloted in the water stressed Okanagan Basin in Canada (Brandes \& Kriwoken, 2006), where CBSM was utilized to understand barriers prior to conservation program design and implementation. Barriers included the myth of water abundance, reduction in water use compromises standard of living, water management responsibilities in the basin are fragmented between Canada and the United States, and certain stakeholders have historical use patterns (Brandes \& Kriwoken, 2006). A review of three CBSM programs designed to reduce water consumption found that CBSM can be an effective tool for water savings, and forestalling capital improvements. A study conducted in southwest Florida encouraged residents to skip lawn watering every other week through various media outlets. Over $19 \%$ of residents skipped watering every other week resulting in a water savings of 1.2 billion gallons over the life of the study period (Myers, 2016). The city of Barrie, Ontario needed to reduce water consumption or construct a new water treatment plant, the city piloted a CBSM program that replaced shower heads and toilets with low-flow technology and reported a water savings of 16 gallons/day/person. A similar threat faced the city of Kamloops, British Columbia which responded by implementing water restrictions and promoting less frequent outdoor irrigating. The program reduced overall household consumption by 14.5\% (Myers, 2016). To utilize these tools of outreach and persuasion, water managers must develop a keen understanding of their target audiences to increase the efficacy of outreach campaigns.

Table 3-1. Current Literature pertaining to Social Marketing and Audience Segmentation

\begin{tabular}{lllll}
\hline Author(s) & Date(Year) & Study Area & Methods & \multicolumn{1}{c}{ Key Findings } \\
$\begin{array}{l}\text { Lede \& } \\
\text { Meleady }\end{array}$ & 2019 & NA & Literature Review & $\begin{array}{l}\text { Social influence strategies are } \\
\text { good approaches for WDM } \\
\text { strategies as they are cost } \\
\text { effective, readily deployable, }\end{array}$
\end{tabular}


result in substantial water reductions.

\begin{tabular}{|c|c|c|c|c|}
\hline Sharma & 2018 & Punjab, India & Survey & $\begin{array}{l}\text { Awareness of effects of climate } \\
\text { change impacts upon on water } \\
\text { resources should be instilled in } \\
\text { farming families to make them } \\
\text { water saving conscious. }\end{array}$ \\
\hline Landon et al. & 2018 & College Station, Texas & Mixed Methods; Survey & $\begin{array}{l}\text { Information-based programs } \\
\text { had an impact on water use in } \\
\text { households which received } \\
\text { persuasive messaging regarding } \\
\text { past consumption }\end{array}$ \\
\hline $\begin{array}{l}\text { Domegan et } \\
\text { al. }\end{array}$ & 2016 & Europe & Focus groups & $\begin{array}{l}\text { Coupling systems thinking with } \\
\text { social marketing is necessary to } \\
\text { create effective and coherent } \\
\text { behavioral change campaigns. }\end{array}$ \\
\hline Lowe et al. & 2015 & Australia & Survey & $\begin{array}{l}\text { Perceived behavioral control } \\
\text { was a significant predictor of } \\
\text { behavioral intent and attitudes } \\
\text { have the greatest effect upon } \\
\text { intentions to consume less } \\
\text { water. }\end{array}$ \\
\hline Lowe et al. & 2014 & Southeastern Australia & Focus groups & $\begin{array}{l}\text { Conservation increases if water } \\
\text { managers are perceived to } \\
\text { manage resources effectively, } \\
\text { structural approaches, and } \\
\text { attitudinal change promote } \\
\text { conservation. }\end{array}$ \\
\hline $\begin{array}{l}\text { Seyranian et } \\
\text { al. }\end{array}$ & 2014 & Los Angeles, CA & Mixed methods; Survey & $\begin{array}{l}\text { Social norms, social identity, } \\
\text { and personal identity } \\
\text { approaches provided more } \\
\text { effective avenues for promoting } \\
\text { water conservation. }\end{array}$ \\
\hline $\begin{array}{l}\text { Dolnicar and } \\
\text { Hurlimann }\end{array}$ & 2010 & Australia & Survey & $\begin{array}{l}\text { Attitudes did not manifest } \\
\text { themselves in actual behavior. } \\
\text { Barriers to conservation } \\
\text { behavior were inconvenience, } \\
\text { and costs of water saving } \\
\text { appliance. }\end{array}$ \\
\hline Monroe & 2003 & NA & Literature Review & $\begin{array}{l}\text { Audience research enables } \\
\text { social marketers to target those } \\
\text { values that are most likely to } \\
\text { move people towards a } \\
\text { particular objective. }\end{array}$ \\
\hline Syme et al. & 2000 & NA & Literature review & $\begin{array}{l}\text { Information based water savings } \\
\text { campaigns have been met with } \\
\text { limited success. }\end{array}$ \\
\hline
\end{tabular}




\begin{tabular}{|c|c|c|c|c|}
\hline $\begin{array}{l}\text { Altman and } \\
\text { Petkus }\end{array}$ & 1994 & NA & Policy analysis & $\begin{array}{l}\text { Social marketing during the } \\
\text { public policy process can } \\
\text { articulate policy goals and } \\
\text { encourage adoption and } \\
\text { acceptance of environmental } \\
\text { policies. }\end{array}$ \\
\hline Geller & 1989 & NA & Literature review & $\begin{array}{l}\text { Coupling applied behavior } \\
\text { analysis and social marketing } \\
\text { can increase the effectiveness of } \\
\text { environmental protection } \\
\text { campaigns. }\end{array}$ \\
\hline N. Myers & 2016 & North Carolina, U.S. & Literature Review & $\begin{array}{l}\text { All CBSM programs were } \\
\text { found to produce significant } \\
\text { reductions in water use. }\end{array}$ \\
\hline $\begin{array}{l}\text { Brandes and } \\
\text { Kriwoken }\end{array}$ & 2006 & $\begin{array}{l}\text { Okanagan Basin, } \\
\text { Canada }\end{array}$ & Policy analysis & $\begin{array}{l}\text { Stakeholder outreach and } \\
\text { education campaigns were } \\
\text { necessary for ongoing } \\
\text { conservation measures. }\end{array}$ \\
\hline $\begin{array}{l}\text { McKenzie- } \\
\text { Mohr }\end{array}$ & 2000 & Canada & Literature review & $\begin{array}{l}\text { Effective social marketing } \\
\text { reduced water consumption in } \\
\text { the experimental group by } 66 \% \text {. }\end{array}$ \\
\hline Ibrahim et al. & 2018 & United Arab Emirates & Audience Segmentation & $\begin{array}{l}\text { Identified three distinct water } \\
\text { users' segments. Segmentation } \\
\text { can increase return on } \\
\text { investment for water } \\
\text { conservation programs. }\end{array}$ \\
\hline Warner et al. & 2016 & Florida, U.S. & $\begin{array}{l}\text { Survey; Audience } \\
\text { Segmentation }\end{array}$ & $\begin{array}{l}\text { Normative beliefs, attitudes, and } \\
\text { perceived behavioral control } \\
\text { most predictive of high-water } \\
\text { conservation. }\end{array}$ \\
\hline Browne et al. & 2013 & United Kingdom & Audience Segmentation & $\begin{array}{l}\text { Focus theoretical perspectives } \\
\text { on water use practices in favor } \\
\text { of demographic variables. } \\
\text { Changing the unit of analysis } \\
\text { from individuals to practices. }\end{array}$ \\
\hline $\begin{array}{l}\text { Maibach et } \\
\text { al. }\end{array}$ & 2011 & U.S. & $\begin{array}{l}\text { Survey and latent class } \\
\text { analysis }\end{array}$ & $\begin{array}{l}70 \% \text { of those surveyed were } \\
\text { concerned about global } \\
\text { warming and supportive of } \\
\text { policy responses. To enhance } \\
\text { the impact of social marketing } \\
\text { campaigns, organizations } \\
\text { should selectively target } \\
\text { segments of audiences over an } \\
\text { undifferentiated general } \\
\text { population. }\end{array}$ \\
\hline Willis et al. & 2011 & $\begin{array}{l}\text { Gold Coast city, } \\
\text { Australia }\end{array}$ & $\begin{array}{l}\text { Mixed methods; } \\
\text { Audience Segmentation }\end{array}$ & $\begin{array}{l}\text { Residents with positive } \\
\text { environmental and water } \\
\text { conservation attitudes } \\
\text { consumed significantly less } \\
\text { household water use. }\end{array}$ \\
\hline
\end{tabular}




\begin{tabular}{|c|c|c|c|c|}
\hline Jones et al. & 2005 & Australia & Audience segmentation & $\begin{array}{l}\text { Four basic categories of } \\
\text { variables for audience } \\
\text { segmentation exist: geographic, } \\
\text { demographic, psychographic, } \\
\text { and behavioral. }\end{array}$ \\
\hline $\begin{array}{l}\text { Straughn and } \\
\text { Roberts }\end{array}$ & 1993 & NA & Audience segmentation & $\begin{array}{l}\text { Psychographic criteria are more } \\
\text { effective than demographic } \\
\text { criteria in environmental } \\
\text { segmentation. }\end{array}$ \\
\hline $\begin{array}{l}\text { Ghavifelder } \\
\text { et al. }\end{array}$ & 2017 & Auckland, NZ & $\begin{array}{l}\text { Spatial Analysis; } \\
\text { Audience Segmentation }\end{array}$ & $\begin{array}{l}\text { Identified urban clusters based } \\
\text { upon per capita water use and } \\
\text { household income. More } \\
\text { intensified multi-unit housing } \\
\text { developments will not } \\
\text { significantly affect per capita } \\
\text { water consumption. }\end{array}$ \\
\hline $\begin{array}{l}\text { Nielsen- } \\
\text { Pincus et al. }\end{array}$ & 2014 & $\begin{array}{l}\text { Willamette Valley, } \\
\text { OR }\end{array}$ & Audience segmentation & $\begin{array}{l}\text { Developed a typology of four } \\
\text { landowner types. Identified } \\
\text { differences in each types land } \\
\text { management strategy and } \\
\text { spatial distribution. }\end{array}$ \\
\hline
\end{tabular}

\section{Audience Segmentation (AS)}

Audience or market segmentation is a common method among social marketing, political science, and climate adaption campaigns (Maibach, Leiserowitz, Roser-Renouf, \& Mertz, 2011). Audience segmentation (Table 3-1) is an important strategic planning asset because it defines homogenous critical attributes of interest (Maibach et al., 2011). In order to be effective, audience segments must have five attributes: (1) segments must be distinct from one another and members of each segment must be similar enough for a marketing strategy to be effective; (2) segments must have direct relevance to the mission of the outreach campaign; (3) segments must be large enough to justify the allocation of resources; (4) the segment status of individuals must be readily identifiable; and (5) the outreach campaign organization must be able to target one or more of the identified segments (Maibach et al., 2011). The novel approach of this analysis will be to segment 
water customers into "water customer types" based upon water conservation and climate attitudes, and investigate the spatial distribution of these segments.

The majority of segmentation studies focus on four basic categories of variables: geographic, demographic, psychographic, and behavioral (S. Jones, L. Rees, Danika Hall, 2005). Research shows that psychographic criteria are often more effective in profiling and segmentation for environmental programs than demographic characteristics (Straughan \& Roberts, 1993). A segmentation study conducted in Gold Coast city Australia found that water customer segments with positive environmental and water conservation attitudes consumed significantly less water in total, and across different household water use behaviors compared to segments with a moderately positive attitudinal concern (Willis, Stewart, Panuwatwanich, Williams, \& Hollingsworth, 2011b). Segmentation analysis of outdoor irrigators $(\mathrm{n}=249)$ in Florida found normative beliefs, attitudes, and perceived behavioral control were variables in a segment which demonstrated the highest water conservation (Laura A. Warner et al., 2016). The focus of attitudinal and behavioral segmentation in water conservation studies has been found to increase returns on resources invested and increase program success (Ibrahim et al., 2018)

Clustering is a method used in segmentation to identify a set of distinct groupings in a sample (categorization), and the assignment (classification) of the cases in the sample into those groups (Browne, Pullinger, Anderson, \& Medd, 2013). To develop a taxonomy of the different audience segments, cluster analysis is an appropriate approach as there are no a priori assumptions about important between research objects, save the variables selected for analysis (Sausen, Tomczak, \& Herrmann, 2005). Cluster analysis has been a popular method for investigating environmental issues ranging from identifying private landowner typologies for purposes of 
outreach and restoration (Metcalf, Gruver, Finley, \& Luloff, 2015; Nielsen-Pincus, Ribe, \& Johnson, 2015), to assessing perceived climate change risks (Ashworth, Jeanneret, Gardner, \& Shaw, 2011; Leiserowitz, 2012), and water customer demand management (Browne et al., 2013; Cominola et al., 2018). A case-study of water-electricity customer demand conducted audience segmentation of $(\mathrm{n}=1000)$ households in Burbank, California found that psychographic variables such as conservation attitudes were significant drivers of reduced water and electricity consumption (Cominola et al., 2018).

\section{Spatial Audience Segmentation (SAS)}

We seek to go a step further and not only segment water customer into types, but to map these types on to our sample to determine if customer types exhibit some discernable spatial pattern. Based upon our review of the literature (Table 3-1), the spatial analysis of water customer segments is absent in the literature and will be a novel contribution to this burgeoning field. Segmenting based upon attitudinal and spatial variables have been utilized in creating landowner typologies in the Eugene, OR area. However, landowner segments were assigned to likely land cover classes based upon GIS data, not ascribed to original survey respondents themselves (Nielsen-Pincus et al., 2015). Researchers in Auckland, New Zealand have used spatial segmentation of building types which are responsible for water consumption., However the study did not analyze the attitudinal factors of individuals, merely building characteristics and water consumption rates (Ghavidelfar et al., 2017).

The understanding of water customer attitudes towards SWPP along with water conservation and behavior, their reduction to identifiable customer types, and their spatial distribution lays the groundwork for a targeted informational campaign on behalf of water managers to their customers. Now that water managers understand their customer types and 
distribution, they can begin framing targeted messages to each segment in order to maximize the effectiveness of their outreach campaigns. This level of precision in water customer segmentation would be a great benefit to resource managers and policy makers.

\section{Research Purpose and Questions}

The purpose of this study was to identify attitudinal and spatial segments of water customers within the Clackamas River Watershed to lay the groundwork for effective social marketing strategies that promote pro-watershed protection and water conservation results. This information will enable watershed managers to target outreach campaigns with more precision, maximizing the use of resources and the efficacy of the campaign. This research will employ findings from a watershed protection and water conservation survey distributed to 1,200 Portland Metropolitan Area (PMA) water customers.

Research Questions:

1. What customer types exist among Clackamas water utility customers?

2. Does the spatial distribution of each customer type exhibit clustering or hot spots?

3. Are there significant aggregations by sociodemographic group?

\section{Data and Methods}

Study Area 
The Clackamas Watershed is a mixed-mosaic of public, private and tribal land. The watershed supplies water for agricultural, municipal, and domestic purposes. In addition, the watershed is also critical habitat for anadromous fish species, hydroelectric power generation, and ample recreational opportunities. At present, eight water districts draw from the Clackamas River to provide drinking water to over 300,000 people. Five water districts participated in this study: City of Lake Oswego, Clackamas River Water, Sunrise Water Authority, South Fork Water Board, City of Estacada, Oak Lodge Water Services, and the City of Gladstone. The county for which the watershed is named is a rapidly growing with an annual growth rate of $1.1 \% /$ year. Population growth is due largely to in-migration from outlying counties. This growth pressure has caused the county to designate 13,750 acres of rural land fit for residential development (Chun et al., 2018). The primary water use in the watershed is for irrigation (44.62 Million gallons/day), followed by household consumption (27.9 Million gallons/day) (Dieter et al. 2015). This large quantity for household consumption combined with increased population growth make residential consumption and watershed protection and ideal target for water managers interested in reducing water demand.

Data

A survey was distributed between March and June of 2016 to 1,200 PMA residents in an attempt to gauge their attitudes towards watershed protection and conservation. We employed a mixed-mode survey design utilizing mail and internet surveys following the Dillman four-contact tailored design method (Dillman 2011). Surveys were either returned by mail ( $\mathrm{n}=315)$ or completed by an online version of the questionnaire $(n=91)$. A total of $(n=406)$ questionaries' were returned, resulting in a $34 \%$ response rate to our questionnaire from our sample population. Average 
nonresponse to survey items was $20 \%$. Surveys were either returned by mail or respondents submitted their responses via an online survey instrument.

Variables

Table 3-2. Variables used in Segmentation Analysis

\begin{tabular}{|l|l|}
\hline Survey Items & Scale \\
\hline Income & Nine \$25,000 bins for tax year 2014 \\
\hline Age & Numeric entry \\
\hline Education Level & Less than High School Degree (1) to Graduate or Professional Degree (6) \\
\hline Political Leanings & 5-point Likert scale ranging from Very Conservative (4) to Very Liberal (0) \\
\hline Water Conservation Attitudes & 5-point Likert scale ranging from Strongly Agree (4) to Strongly Disagree (0) \\
\hline $\begin{array}{l}\text { Pacific Northwest Climate } \\
\text { Beliefs }\end{array}$ & 5-point Likert scale ranging from Strongly Agree (4) to Strongly Disagree (0) \\
\hline Climate Impact Index & 5-point Likert scale ranging from Strongly Agree (4) to Strongly Disagree (0) \\
\hline Trust Index & 5- point scale ranging from Unsure (0) to High Trust (4) \\
\hline Place Attitude Index & 5-point Likert scale ranging from Strongly Agree (4) to Strongly Disagree (0) \\
\hline
\end{tabular}

A pro conservation variable was derived by the mean agreement of the attitudes towards water conservation items (Table 3-2). This variable is an amalgamation of water conservation attitudes such as: 1) “I think about water conservation daily", 2) "If I knew my neighbors were involved in a water conservation program, I would be more likely to participate". Pacific Northwest Climate Beliefs were assessed using a four-item scale. The four-item scale was reduced to a single variable by taking the mean of the four items to produce a Pacific Northwest Climate Beliefs Index, scores range 0 to 4 (Table 2). A climate impact index score was created by taking the average climate impact attitudes for each respondent, scores range from 0 to 4 . Trust in the following groups was measured on a 5-point scale ranging from "Unsure" to "High Trust": Federal Natural Resource Agencies, State Natural Resource Agencies, Local Government, Local Water Providers, Private Landowners, Non-Profit Organizations, Urbanites that use the watershed, and local Soil and Water Conservation Districts. A Trust Index was computed by taking the mean of the eight items for each 
respondent. Place attitudes were assessed on a 5-point Likert scale ranging from Strongly Disagree to Strongly Agree. Respondents were asked to whether they agree or disagree with a series of statements about the Clackamas Watershed. A Place Attitude Index was created by taking the mean score to the nine question items.

In order to map customer types onto survey respondents' residence, geospatial data was obtained from the Metro Regional Land Information System (RLIS) master address taxlot dataset. Respondent unique identifiers and addresses were merged using a table join in ArcGIS 10.5. To assess if customer types exhibited clustering behavior, a "Service Area Boundary" polygon was created to encompass all of the water districts that participated in the study, with the exception of the City of Estacada where only five responses. In order to assess clustering, a boundary measure must have a contiguous area. Since very few responses came from this water district $(n=5)$, they were excluded from analysis.

\section{Data Analysis}

Analytical Framework

The following diagram (Figure 3-1) outline the analytical framework for this study. The concept is as follows: 1) Conduct univariate summary on variables of interest, 2) Examine exploratory correlations of variables to detect possibilities of multi-collinearity, 3) Perform hierarchical cluster analysis on water customer survey respondents' to determine heterogenous customer types, 4) Merge customer types onto spatial locations of survey respondents, 5) Conduct Getis-Ord Gi Optimized hot spot analysis to assess areas of high clustering of customer types, and 
6) Conduct Geographically Weighted Regression (GWR) to determine the spatial variation of socio-demographic variables on water conservation and climate impact attitudes for each customer.

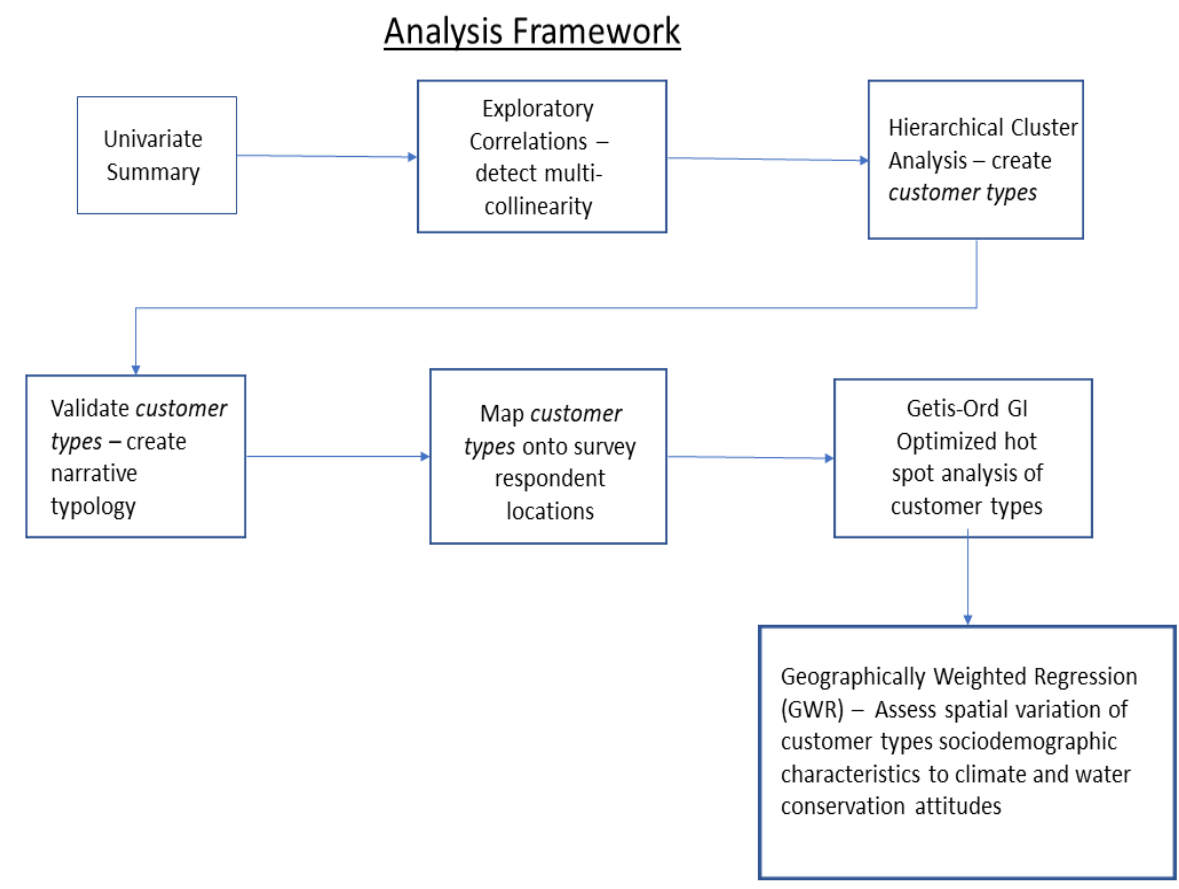

Figure 3-1. Analytical Framework

Univariate Summary

We will be compared sociodemographic variables to American Community Survey 20132017 data to assess the representativeness of our sample compared to Clackamas County homeowners. Univariate statistical summaries of all other analysis variables (Table 3-3) will also be computed.

\section{Exploratory Correlations}

We will construct and analyzed parametric Pearson's $r$ bivariate correlations of sociodemographic, climate, water conservation, trust, and place variables (e.g. Income, Age, Education Level, Political Leanings, Pro-Water Conservation, Pacific Northwest Climate Beliefs, 
Climate Impact Beliefs, Trust Index, Place Attitude Index), which have been identified in the literature. If proposed explanatory variables are highly correlated to each other, one will be omitted from the subsequent analysis.

\section{Water Customer Types - Hierarchical Cluster Analysis}

We sought to segment customers into heterogenous groups we refer to as customer types. Attitudinal variables identified from the examination of the aforementioned correlation matrix (e.g. pro-water conservation attitudes, climate change impacts, trust, and place attitudes) were used in a hierarchical cluster analysis to separate customers into distinct customer types. Hierarchical Cluster analysis is common technique of unsupervised clustering used in data analysis for establishing a hierarchy of clusters (Lin, Van Poucke, Zhang, Lan, \& Murtagh, 2017). Hierarchical clustering detects groups of closely related objects by constructing a dendrogram. Branches of the dendrogram represent the desired clusters. Cluster detection involves "pruning" the dendrogram to determine an optimal cluster solution (Langfelder, Zhang, \& Horvath, 2008). Water customer types are derived through the construction of a dendrogram. The dendrogram is "pruned" at a height where cluster size and membership are relatively equal and heterogenous from one another. Cluster validation is determined through inspection of a variety of validation indices such as Hubert's gamma coefficient, Dunn index, and the corrected rand index (Gordon, 1999; Halkidi, Batistakis, \& Vazirgiannis, 2002; Newell, Cook, Hofmann, \& Jannink, 2013). Upon completion of cluster validation, comparison of variable means and narrative typologies of water customer types are created. Internal validation measures utilize the dataset and clustering partition as input and uses intrinsic information within the data to assess cluster validity (Brock, Pihur, Datta, \& Datta, 2015). 
We will compare three common internal validity measures for our clustering solution and found our clusters to be acceptable. Our clusters will be evaluated based upon connectivity, Dunn Index, and average silhouette width. Connectivity is an assessment of an observations distance to its nearest neighbor within the cluster. This value is on a scale of 0 to infinity. Optimal cluster solution should minimize connectivity. The Dunn Index is the ratio of the smallest distance between observations not in the same cluster to the largest intra-cluster distance. The Dunn Index ranges between zero and infinity, with higher values indicating an optimal cluster solution. Silhouette Width is the mean of each observation's silhouette value. A silhouette value is the degree of confidence in the clustering membership of a given observation. Good clustering solutions have values near 1 and poor cluster solutions have values approaching -1 (Brock et al., 2015). To externally validate our customer types, we joined customer type membership to a subset of our original sample containing household water consumption data $(\mathrm{n}=215)$. We performed a two-sample T-test to assess if there were significant differences in water consumption by customer type. This was performed to assess if water conservation attitudes resulted in observable differences in water consumption behavior.

\section{Spatial Distribution of Water Customer Types}

To assess if customer types exhibit any spatial clustering, we will perform a Getis-Ord Gi* Optimized hot spot analysis. The Getis-Ord Gi* analysis is a method to assess spatial autocorrelation. This analysis determines the inner spatial heterogeneity of points or polygons to recognize hot spot and cold spot regions within an area of interest. Hot spots or cold spots are determined based on whether a particular area is surrounded by lower or higher point densities than expected relative to the mean of the distribution. Results produce a raster map which identifies hot spots and cold spots, and provides $95 \%$ confidence levels to determine areas of spatial significance 
(Bagstad, Semmens, Ancona, \& Sherrouse, 2017; Karimi, Brown, \& Hockings, 2015; Yang \& Liu, 2014). Hotspot analysis was performed using the Optimized Hot Spot analysis tool in ArcGIS version 10.6.

Factors determining spatial variation of customer types - Geographically Weighted Regression (GWR)

GWR is a method used to examine local relationships between dependent and explanatory variables by constructing a separate equation for every feature of interest within a certain bandwidth. Spatial autocorrelation is a process where adjacent regions display similarities or dissimilarities (L. A. House-Peters \& Chang, 2011). GWR models are often compared to global Ordinary Least Squares (OLS) models to determine if spatial effects contribute to the variation explained by the model. GWR models are commonly employed in water resource research to address a variety of issues ranging from determinants of water consumption for single family residences (Villar-Navascués \& Pérez-Morales, 2018; Wentz \& Gober, 2007), to determining how spatial development patterns influence water use (Sanchez, G. M., Smith, J. W., Terando, A., Sun, G., \& Meentemeyer, 2018).

We had identified two important analysis variables from previous chapters that were significant for support of source water protection and reduced water consumption (e.g., climate impact attitudes, pro-water conservation attitudes), respectively. We are unable to measure water consumption or support for source water protection directly for each customer type; therefore, we will use the aforementioned variables as surrogates. We sought to determine how sociodemographic variables influenced climate impact attitudes and pro-water conservation attitudes 
within the water service boundary for each customer type. We conducted an OLS regression and two GWR analyses for each customer type to assess this variability. All regression analyses were performed using the "spgwr" package in Rstudio version 5.3.

We have a total of four OLS models in our study, two for each customer type. In our first equation, pro water conservation attitudes are our dependent variable, and age, education, political attitudes, and income are our independent variables. In our second equation climate impact attitudes are our dependent variables, with the previously mentioned independent variables functioning the same in our second model.

The GWR calculates a specific set of parameters (y-intercept, $\beta_{0}$, and independent coefficients $\beta_{\mathrm{k}}$ ) for each observation $(i)$, defined by the geographic coordinates of $(u, v)$, see Equation 1.

$$
y_{i}=\beta_{0}\left(u_{i}, v_{i}\right)+\sum k \beta_{k}\left(u_{i}, v_{i}\right) x_{i k}+\varepsilon_{i}
$$

Equation 1.

An examination of $r^{2}$ values and Akaike Information Criterion (AIC) for both models will be compared to determine if the GWR outperforms the OLS model in explaining variation in water conservation and climate impact attitudes for both customer types. We will plot the pseudo- $r^{2}$ values of both customer types to see where the model is performing well or not. We will plot spatially varying coefficients of significant variables for each customer type to explore emergent spatial patterns. Coefficient point estimates will be interpolated in ArcGIS version 10.6 to produce a smoothed raster surface of coefficient values in an effort to preserve respondent anonymity. 


\section{Results}

Univariate Summary

Table 3-3. Descriptive statistics of analysis variables

\begin{tabular}{|c|c|c|c|c|}
\hline Variables & $\mathbf{n}$ & mean & sd & median \\
\hline Age & 396 & 59.69 & 14.04 & 61 \\
\hline Education & 395 & 3.45 & 1.4 & 4 \\
\hline Political leanings & 398 & 1.79 & 1.16 & 2 \\
\hline Income & 356 & $75 \mathrm{k}-99 \mathrm{k}$ & NA & $75 \mathrm{k}-99 \mathrm{k}$ \\
\hline PNW Climate Index ${ }^{a}$ & 370 & 2.76 & 0.86 & 3 \\
\hline Climate Impact Index ${ }^{\mathrm{a}}$ & 371 & 2.65 & 0.7 & 2.62 \\
\hline Trust Index ${ }^{\mathrm{a}}$ & 411 & 1.74 & 0.74 & 1.89 \\
\hline Place Attitude Index ${ }^{a}$ & 423 & 1.99 & 0.82 & 2 \\
\hline
\end{tabular}

${ }^{\text {a }}$ Based on averaged 5-point Likert Scale Data

Median age of survey respondents was 59, with the majority possessing a bachelor's degree or higher (Table 3-3). We specifically targeted homeowners in our sample as we felt they would be most likely responsible to pay their water bills. Compared to the US Census American Community Survey Profile (2013-2017) which exhibits a median age in Clackamas County of 41, our respondents are much older. Educational attainment of respondents was high, with 59\% reporting a bachelor's degree or higher. In comparison, $43 \%$ of Clackamas County homeowners possess a bachelors' degree or higher. Homeowners and heads of household are associated with increased educational attainment (Segal \& Sullivan, 1998). This may explain the slight bias towards higher educational attainment and income. Given that median age of respondents was 59, homeowners in Clackamas County between the ages of 45 to 64 have a median household income of $\$ 87,689$, indicating that our sample is representative of the middle-aged homeowner population. Respondents displayed a bias towards liberal political affiliation with $44 \%$ liberal, $28 \%$ 
conservative, and 28\% reported no political affiliation. Contrasted with 2014 Clackamas County voter registration, with 36\% Democrat, 31\% Republican, and 33\% Other. We make the assumption that party affiliation with Democrat equates to Liberal and Republican to Conservative.

Respondents exhibited agreement that climate in the PNW was changing $(\mathrm{M}=2.8, \mathrm{SD}=0.83)$, concern for climate change impacts $(\mathrm{M}=2.65, \mathrm{SD}=0.7)$ and similar attitudes towards being pro water conservation $(\mathrm{M}=2.53, \mathrm{SD}=0.77)$. Respondent's revealed relatively low trust $(\mathrm{M}=1.74, \mathrm{SD}$ $=0.74)$, and neutral place attitudes $(\mathrm{M}=1.99, \mathrm{SD}=0.82)($ Table 3-3).

\section{Exploratory Correlations}

A correlation matrix of analysis variables was constructed and visualized in a correlation plot (Figure 2). The results of plotting the correlation matrix yielded illuminating results and had many implications for the next phase of our analysis. Interestingly, there was a strong correlation between PNW climate attitudes and Climate Impacts with Pro water conservation attitudes ( $\mathrm{r}=$ $0.46, \mathrm{p}<0.01 ; \mathrm{r}=0.53, \mathrm{p}<0.01)$, suggesting that respondents with strong water conservation attitudes may also feel strongly about climate change impacts locally and regionally. Not surprisingly, there were strong negative correlations between Political Attitudes and PNW climate attitudes, Pro water conservation, Climate Impacts, and education $(r=-0.41, p<0.01 ; r=-0.29, p<$ $0.01 ; \mathrm{r}=-0.48, \mathrm{p}<0.01 ; \mathrm{r}=-0.23, \mathrm{p}<0.01)$ respectively.

Ultimately, the correlation matrix (Figure 3-2) illustrates a general profile of the types of water customers in our sample. The political attitudes variable was scaled from "Very Liberal" to "Very Conservative", indicating as a respondent identifies as more conservative, there was a negative correlation with education, PNW climate attitudes, Climate Impacts, and pro water 
conservation attitudes. There was a positive correlation between Climate Impacts and Income with education, which is likely given that individuals with higher educational attainment are likely to report higher incomes $(r=0.21, \mathrm{p}<0.01 ; \mathrm{r}=0.33, \mathrm{p}<0.01)$. The rest of the variables had relatively weak positive correlations $(\mathrm{r}<0.30)$. Perhaps the most important discovery during our inspection of the correlation matrix was the evidently high positive correlation between PNW Climate Attitudes and Climate Change impacts $(\mathrm{r}=0.57, \mathrm{p}<0.01)$. Given that the goal of this analysis is to segment customers into heterogenous groups, the PNW Climate Attitudes variable is excluded from any further analyses. We go a step further in an effort to produce the most distinguishable parsimonious customer types, we limit our analysis variables for segmentation to four attitudinal variables of interest that were demonstrably significant in the analyses of the previous two chapters. Variables for purposes of segmentation are pro-water conservation attitudes, climate change impacts, trust, and place attitudes. 


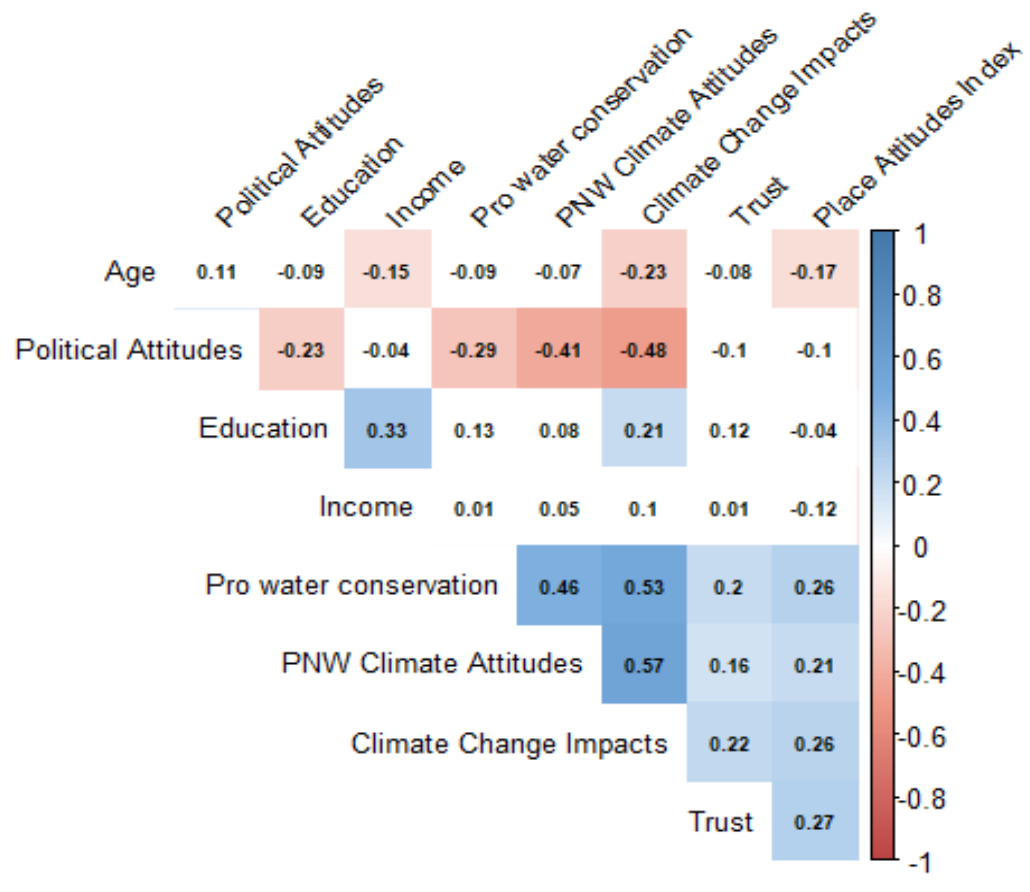

Figure 3-2. Exploratory Correlations of Analysis Variables 


\section{Water Customer Segments}

We performed a hierarchical cluster analysis and identified two optimal cluster solutions. Visual inspection of the hierarchy tree (dendrogram) exhibited two clear groups (Figure 3-3).

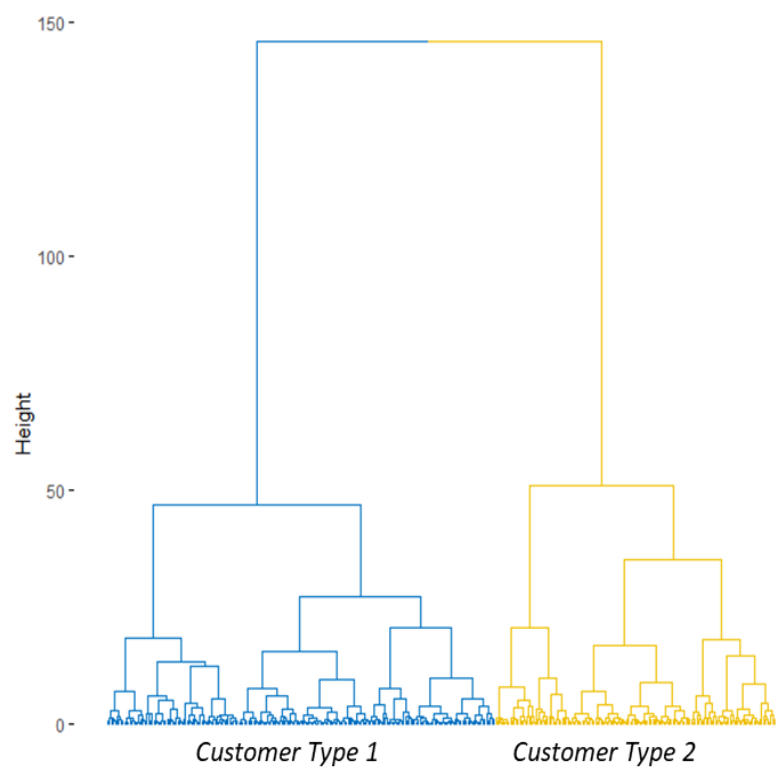

Figure 3-3. Water Customer Dendrogram

Our optimal cluster solution scores were (connectivity $=3.86$, Dunn Index $=0.21$, and average silhouette width $=0.395$ ). Scores for connectivity and silhouette width are acceptable, the Dunn Index score is low and could be higher, however, this solution was deemed best given the variables of interest and purpose of our analysis. We performed a multiple analysis of variance (MANOVA) on the final cluster solutions to determine if a statistically significant difference between the solutions existed. All multivariate tests of the MANOVA (Pillai's Trace, Wilk's Lambda, Hotelling's Trace, Roy's Largest Root) were significant at the level of $p<0.001$. This enables us to accept that there are statistically significant differences in cluster means for each 
customer type (Sausen et al., 2005). A plot of the cluster solutions (Figure 3-4) depicts observations grouped into each cluster. It is important to note that some overlaps between the clusters exist, indicating that customer types are not completely heterogenous.

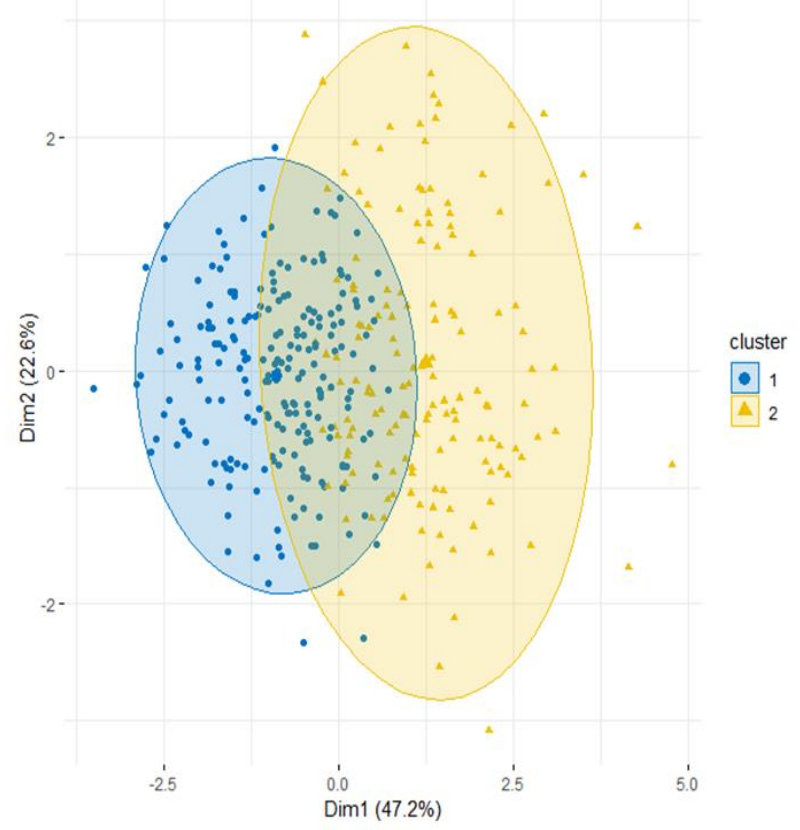

Figure 3-4. Plot of Cluster Solutions

The most effective way of describing cluster solutions in a meaningful way which lends to the creation of a narrative typology of cluster solutions is a comparison of summary statistics for each cluster solution (Table 3-4). A comparison of means between clusters $1(n=210)$ and cluster 2 $(n=152)$ reveal stronger mean attitudes towards climate impacts, pro-water conservation, trust, and place attitudes $(M=3.02, M=2.9, M=2.14, M=2.23)$, respectively. Compared to the weaker mean attitudes of cluster $2(\mathrm{M}=2.14, \mathrm{M}=2, \mathrm{M}=1.29, \mathrm{M}=1.69)$. 
Table 3-4. Summary statistics of cluster solutions

\begin{tabular}{cccccc}
\hline Summary Measure & Cluster & Climate Impact Index & Pro-water conservation & Trust & Place Attitudes \\
\hline \multirow{2}{*}{ Mean } & 1 & 3.02 & 2.9 & 2.14 & 2.23 \\
& 2 & 2.14 & 2 & 1.29 & 1.69 \\
\hline \multirow{2}{*}{ Median } & 1 & 3 & 2.75 & 2.11 & 2.11 \\
& 2 & 2.12 & 2 & 1.33 & 1.89 \\
\hline \multirow{2}{*}{ Standard Deviation } & 1 & 0.511 & 0.585 & 0.469 & 0.723 \\
& 2 & 0.586 & 0.766 & 0.71 & 0.782 \\
\hline
\end{tabular}

Based on a comparison of mean scores over the four attitudinal variables between the two clusters, a narrative typology of each cluster or customer types was created. While this is largely a subjective exercise, we feel that our descriptions accurately and effectively describe each customer type. Customer Type 1 (Water conscious green progressive) feels strongly about climate impacts and pro-water conservation, with neutral trust and place attitudes. Customer Type 2 (Water wasting climate skeptic) is climate and water neutral, with low trust and place attitudes (Figure 3-5).
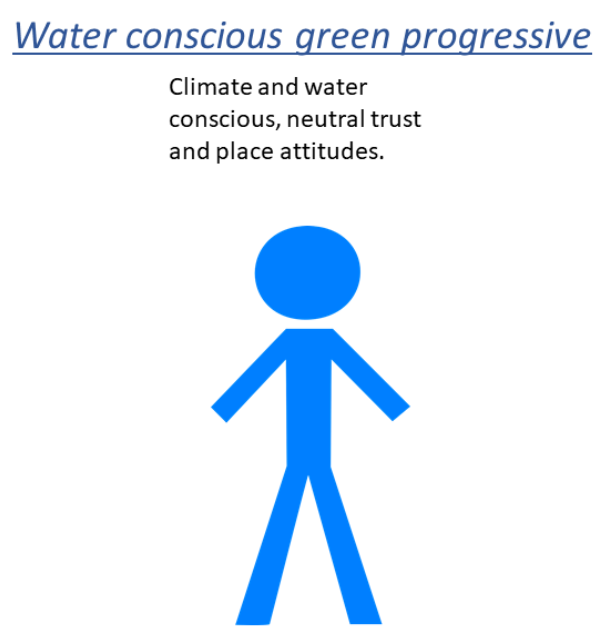

\section{Water wasting climate skeptic \\ Climate and water neutral, low trust and place attitudes.}

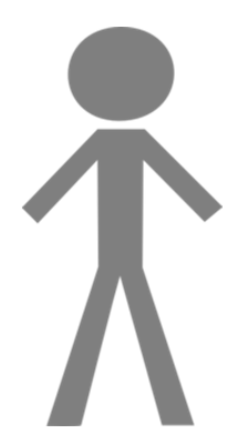

Figure 3-5. Water customer typology 
Table 3-5. Customer Type Characteristics

\begin{tabular}{lcc}
\hline Customer Type Characteristics & Water Conscious Green Progressive & Water Wasting Climate Skeptic \\
\hline Median Age & 59 & 62 \\
Political Leanings & & \\
$\quad$ Liberal & $71 \%$ & $28 \%$ \\
Neutral & $23 \%$ & $56 \%$ \\
$\quad$ Conservative & $5 \%$ & $15 \%$ \\
Income & & \\
$\quad$ Earned $\$ 100 k+$ year & $49 \%$ & $44 \%$ \\
Climate Change Impact Attitudes & & \\
High attitudes & $55 \%$ & $7 \%$ \\
Medium attitudes & $43 \%$ & $67 \%$ \\
Low attitudes & $2 \%$ & $26 \%$ \\
Pro-Water Conservation Attitudes & & \\
$\quad$ High attitudes & $47 \%$ & $11 \%$ \\
Medium attitudes & $50 \%$ & $52 \%$ \\
Low attitudes & $3 \%$ & $37 \%$ \\
Trust & & \\
High trust & $4 \%$ & $0 \%$ \\
Medium trust & $63 \%$ & $16 \%$ \\
Low trust & $33 \%$ & $84 \%$ \\
Place Attitudes & & \\
High attitudes & $0 \%$ & $0 \%$ \\
Medium attitudes & $49 \%$ & $44 \%$ \\
Low attitudes & $35 \%$ & $53 \%$ \\
\hline
\end{tabular}

Water conscious green progressive

The Water conscious green progressive had a median age of 59 , with $69 \%$ possessing a bachelors' degree or higher (Table 3-5). Water conscious green progressives identified is predominantly liberal, with a $71 \%$ reporting liberal to very liberal political leanings, $23 \%$ identified as politically neutral, and 5\% conservative. The water conscious green progressive is in the upper echelon of income brackets with $49 \%$ making $\$ 100,000$ or more per year. Climate Impact attitudes are also extremely important to water conscious green progressives, with $55 \%$ having strong 
climate impact attitudes, $43 \%$ neutral climate impact attitudes, and 2\% low climate impact attitudes. The water conscious green progressive possesses strong pro-conservation attitudes with $47 \%$ strong conservation attitudes, 50\% neutral attitudes, and 3\% low conservation attitudes. Trust was not as high in comparison to the other analysis variables with water conscious green progressives exhibiting $4 \%$ high trust, $63 \%$ neutral trust, and 33\% low trust. Place attitudes also fell within the neutral range of the spectrum with $49 \%$ neutral place attitudes, 35\% low place attitudes, and 15\% missing due to nonresponses.

Water wasting climate skeptics

Water wasting climate skeptics differed greatly from water conscious green progressive in a variety of dimensions. Water wasting climate skeptics had a median age of 62 , with $48 \%$ possessing a bachelors' degree or higher (Table 3-5). Water wasting climate skeptics were more politically neutral and conservative than Type 1 with $56 \%$ neutral, 15\% conservative, and 28\% liberal. Water wasting climate skeptics were reasonably close to water conscious green progressives with $44 \%$ reporting earning $\$ 100,000$ or more per year. Climate impacts are less of a concern for water wasting climate skeptics with only $7 \%$ strong climate impact attitudes, $67 \%$ neutral, and $26 \%$ low climate impact attitudes. Water wasting climate skeptics ranks pro-water conservation as a lower order concern as well with $11 \%$ strong conservation attitudes, $52 \%$ neutral, and 37\% low. Trust may be the most prominent delineator between the two types. High trust was not evident, scores ranged on the lower end of the spectrum with $16 \%$ reporting neutral trust, and $84 \%$ low trust. Place attitudes were also lower with 44\% neutral place attitudes, 53\% low place attitudes, and 3\% missing due to nonresponses. 
Results from our Welch's Two-Sample T-test exhibit no statistically significant difference in mean water consumption behavior between customer types $(\mathrm{t}=-0.63933, \mathrm{df}=140.29, \mathrm{p}$-value $=$ 0.5236). Mean water consumption for Water conscious green progressives was $(M=111.65$ liters/day) and ( $M=187.33$ liters/day) for Water wasting climate skeptics.

\section{Spatial Distribution of Customer Type Hotspots}

The following map (Figure 3-6) depicts the spatial distribution of each customer type: Water conscious green progressives and Water wasting climate skeptics, and where there are significant clustering locations (Hot Spots), and significant dispersion (Cold Spots) exist. An interpretation of the map (Figure 6) reveals that there are significant Hot Spots for water conscious green progressives, in Happy Valley, Lake Oswego, Milwaukie, West Linn, and Oregon City. 


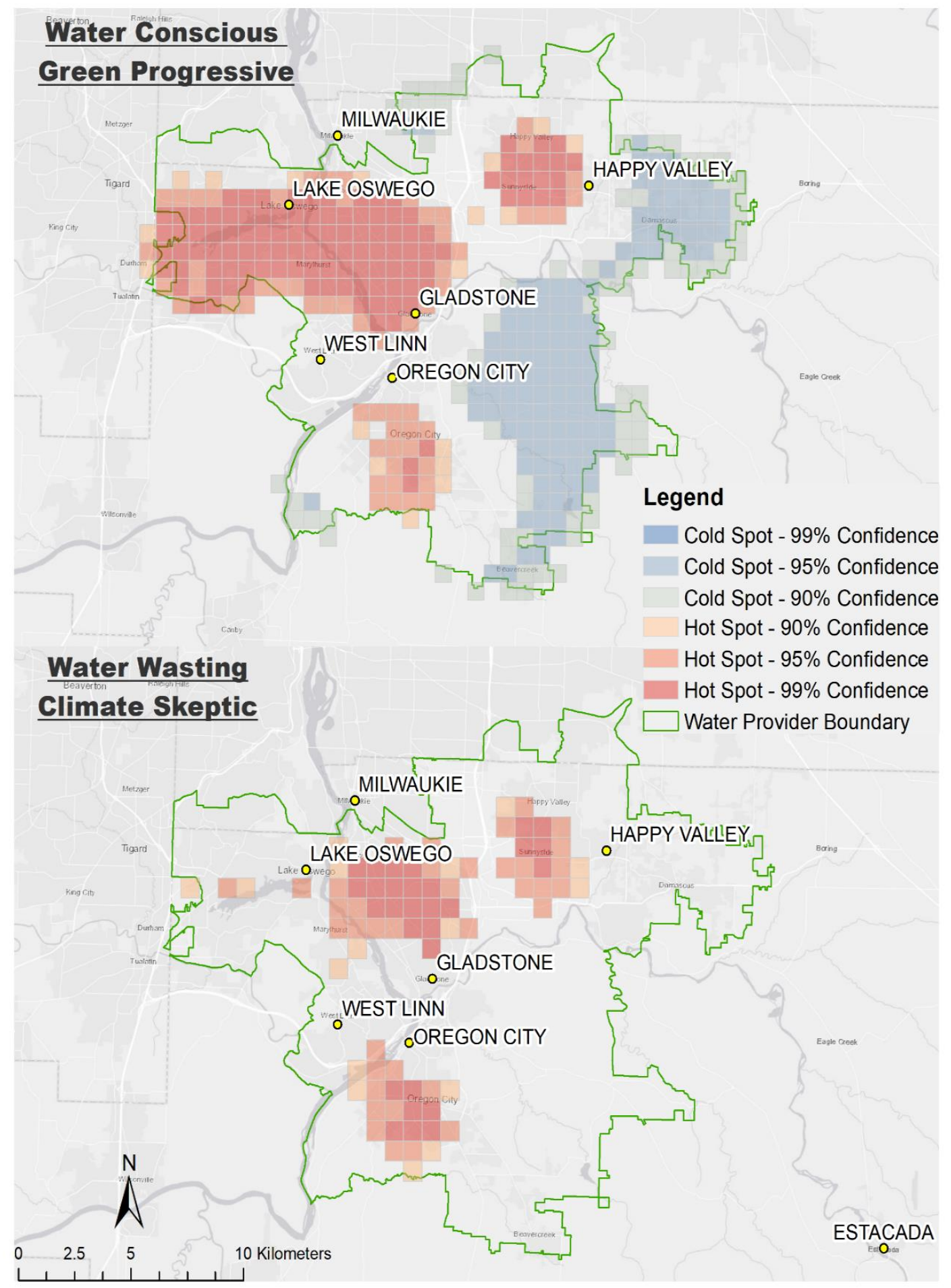

Figure 3-6. Getis-Ord Gi* Optimized Hot Spot Analysis of Customer Types 
Visual inspection reveals significantly high clustering (e.g. 90-95\% confidence) of water conscious green progressives in Lake Oswego, Milwaukie, and Happy Valley, with cold spots in the eastern more rural portions of the water service provider boundary. In comparison, water wasting climate skeptics demonstrate an absence in Lake Oswego, and are more prominent in Milwaukie, Happy Valley, and Oregon City. Each polygon represents the location of at least one customer type. For water conscious green progressives, three outlier locations were identified and excluded from analysis with a polygon cell size of $222.4 \mathrm{~m}^{2}$. Two outlier locations were found for water wasting climate skeptics and omitted, polygon cell sizes were $251.7 \mathrm{~m}^{2}$.

Factors determining spatial variation of customer types - OLS Regression

Regression results provide valuable understanding of which sociodemographic variables influence the spatial variation of water conservation and climate attitudes among the customer types. The OLS regression models (Table 3-6) explained $1 \%$ of the variation in water conservation, and $9 \%$ of the variation in climate impact attitudes for water conscious green progressives.

Table 3-6. OLS regression model results for Water Conservation and Climate Attitudes by customer type

\begin{tabular}{|c|c|c|c|c|c|c|c|c|c|}
\hline \multicolumn{5}{|c|}{ Water Conscious Green Progressives } & \multicolumn{5}{|c|}{ Water Wasting Climate Skeptics } \\
\hline $\begin{array}{r}\text { Water Conservati } \\
\text { Attitudes Mode }\end{array}$ & & & & & & & & & \\
\hline \multirow[t]{2}{*}{ Parameter } & & & & & Parameter & & & & \\
\hline & Estimate & SE & t-value & Sig & & Estimate & SE & t-value & Sig \\
\hline (Intercept) & 2.643 & 0.259 & 10.217 & $* * *$ & (Intercept) & 2.273 & 0.238 & 9.532 & $* * *$ \\
\hline Age & 0.003 & 0.003 & 0.864 & & Age & 0.003 & 0.003 & 0.804 & \\
\hline Education & -0.010 & 0.035 & -0.275 & & Education & 0.039 & 0.046 & 0.847 & \\
\hline Political leanings & -0.024 & 0.040 & -0.598 & & Political leanings & -0.149 & 0.063 & -2.371 & * \\
\hline Income & 0.037 & 0.018 & 2.005 & $*$ & Income & -0.048 & 0.024 & -1.986 & $*$ \\
\hline Adjusted $r^{2} 0.01$ & & & & & Adjusted $r^{2} 0.04$ & & & & \\
\hline
\end{tabular}




\begin{tabular}{|c|c|c|c|c|c|c|c|c|c|}
\hline $\begin{array}{l}\text { Climate Impact } \\
\text { Attitudes Model }\end{array}$ & & & & & & & & & \\
\hline \multirow[t]{2}{*}{ Parameter } & & & & & Parameter & & & & \\
\hline & Estimate & SE & $\mathrm{t}$ - value & & & Estimate & $\mathrm{SE}$ & t-value & \\
\hline (Intercept) & 3.466 & 0.205 & 16.899 & $* * *$ & (Intercept) & 2.300 & 0.160 & 14.397 & $* * *$ \\
\hline Age & -0.006 & 0.002 & -2.395 & $*$ & Age & 0.002 & 0.002 & 0.945 & \\
\hline Education & -0.004 & 0.028 & -0.147 & & Education & 0.032 & 0.031 & 1.035 & \\
\hline Political leanings & -0.116 & 0.032 & -3.638 & $* * *$ & Political leanings & -0.195 & 0.042 & -4.633 & $* * *$ \\
\hline Income & 0.007 & 0.014 & 0.480 & & Income & 0.026 & 0.016 & 1.625 & \\
\hline Adjusted $\mathrm{r}^{2} 0.09$ & & & & & Adjusted $r^{2} 0.15$ & & & & \\
\hline Nagelkerke $r^{2} 0.14$ & & & & & Nagelkerke $r^{2} 0.21$ & & & & \\
\hline
\end{tabular}

The OLS models for Water wasting climate skeptics explained $4 \%$ of the variation in water conservation and $15 \%$ of the variation in climate impact attitudes, respectively.

Geographically Weighted Regression

The GWR model for water conservation and climate impact attitudes demonstrated slight improvement over the OLS models for Water conscious green progressives explaining $4 \%$ of the variation in water conservation, and $12 \%$ in climate attitudes. The GWR models for Water wasting climate skeptic also performed slightly better explaining $8 \%$ of the variation in water conservation and $21 \%$ in climate attitudes (Table 3-7).

Table 3-7. GWR regression model results for Water Conservation and Climate Attitudes by customer type

\begin{tabular}{lrrrrr}
\hline \multicolumn{5}{c}{ Water Conscious Green Progressives } \\
\hline \multicolumn{7}{c}{ Water Conservation } \\
$\quad$ Attitudes Model
\end{tabular}




\begin{tabular}{|c|c|c|c|c|c|}
\hline Income & 0.0348 & 0.0351 & 0.0364 & 0.0372 & 0.0381 \\
\hline Quasi-Global $r^{2} 0$ & & & & & \\
\hline Climate Impa & & & & & \\
\hline Attitudes Mo & & & & & \\
\hline Parameter & & & & & \\
\hline & Min & Lower Quartile & Median & Upper Quartile & Max \\
\hline (Intercept) & 3.3803 & 3.4107 & 3.4264 & 3.4531 & 3.4767 \\
\hline Age & -0.0060 & -0.0058 & -0.0056 & -0.0054 & -0.0053 \\
\hline Education & -0.0061 & -0.0026 & 0.0000 & 0.0019 & 0.0062 \\
\hline Political leanings & -0.1196 & -0.1164 & -0.1106 & -0.1071 & -0.1036 \\
\hline Income & 0.0046 & 0.0070 & 0.0102 & 0.0114 & 0.0124 \\
\hline
\end{tabular}

Quasi-Global r²0.12

Water Wasting Climate Skeptics

\begin{tabular}{|c|c|c|c|c|c|}
\hline $\begin{array}{r}\text { Water Conserva } \\
\text { Attitudes Mod }\end{array}$ & & & & & \\
\hline \multicolumn{6}{|l|}{ Parameter } \\
\hline & Min & Lower Quartile & Median & Upper Quartile & Max \\
\hline (Intercept) & 2.2219 & 2.2342 & 2.2503 & 2.2817 & 2.3075 \\
\hline Age & 0.0025 & 0.0028 & 0.0030 & 0.0033 & 0.0036 \\
\hline Education & 0.0244 & 0.0279 & 0.0350 & 0.0473 & 0.0543 \\
\hline Political leanings & -0.1501 & -0.1489 & -0.1481 & -0.1470 & -0.1458 \\
\hline Income & -0.0490 & -0.0473 & -0.0463 & -0.0454 & -0.0443 \\
\hline \multicolumn{6}{|c|}{ Quasi-Global $\mathrm{r}^{2} 0.08$} \\
\hline \multicolumn{6}{|c|}{$\begin{array}{l}\text { Climate Impact } \\
\text { Attitudes Model }\end{array}$} \\
\hline \multicolumn{6}{|l|}{ Parameter } \\
\hline & Min & Lower Quartile & Median & Upper Quartile & Max \\
\hline (Intercept) & 2.1494 & 2.1876 & 2.2392 & 2.2728 & 2.3651 \\
\hline Age & 0.0012 & 0.0030 & 0.0036 & 0.0038 & 0.0048 \\
\hline Education & 0.0026 & 0.0139 & 0.0214 & 0.0282 & 0.0352 \\
\hline Political leanings & -0.2114 & -0.2057 & -0.2027 & -0.1831 & -0.1723 \\
\hline Income & 0.0239 & 0.0291 & 0.0340 & 0.0382 & 0.0456 \\
\hline
\end{tabular}

Quasi-Global r $^{2} 0.21$

Comparison of the Akaike Information Criterion (AIC) for the OLS models for water conservation $(\mathrm{AIC}=320.32)$ and climate attitudes $(\mathrm{AIC}=238.51)$ for Water conscious green progressives show a reduction in $\mathrm{AIC}$ in the GWR model $(\mathrm{AIC}=313.01, \mathrm{AIC}=230.34)$, respectively, compared to the 
OLS model. The AIC values also demonstrated a reduction in the GWR models (water conservation: $\mathrm{AIC}=304.06$, climate impacts: $\mathrm{AIC}=193.61$ ) for Water wasting climate skeptics compared to the OLS models $(\mathrm{AIC}=311.85, \mathrm{AIC}=204.47)$ respectively. We can conclude that the variation in water conservation and climate attitudes is explained more effectively by the GWR for both customer types. In an attempt to explore models that predict the greatest spatial variation (Quasi-Global $r^{2}>0.10$ ) for both customer types, maps (Figure 7) were generated to plot the GWR coefficients of each significant variables identified in our OLS model (e.g. Age, Political leanings) Units for each coefficient correspond to their original variable coding scales (Table 3-2). 


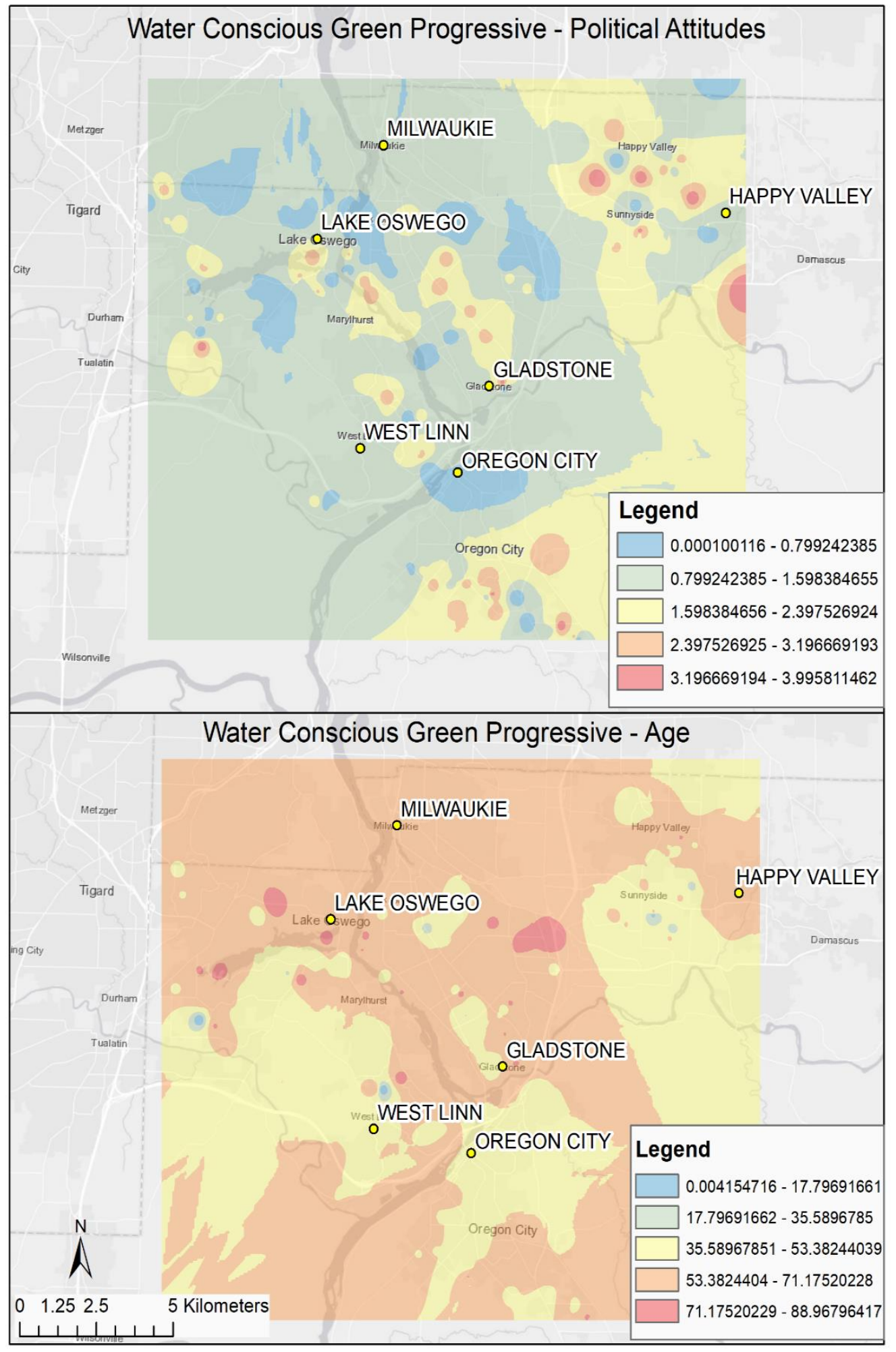

Figure 3-7. GWR coefficients for Political Attitudes and Age 
Visual inspection of the GWR coefficients (Figure 3-7) for the Political Attitudes of Water conscious green progressives reveal liberal political attitudes in Lake Oswego and Milwaukie, with more conservatives congregating in Happy Valley and Oregon City. A similar comparison of age shows younger pockets in Lake Oswego, West Linn, and Oregon City, with isolated areas of older age in Clackamas and parts of Lake Oswego. Water wasting climate skeptics demonstrate a preponderance (Figure 8) of conservative political attitudes in Gladstone, Milwaukie, and Oregon City. 


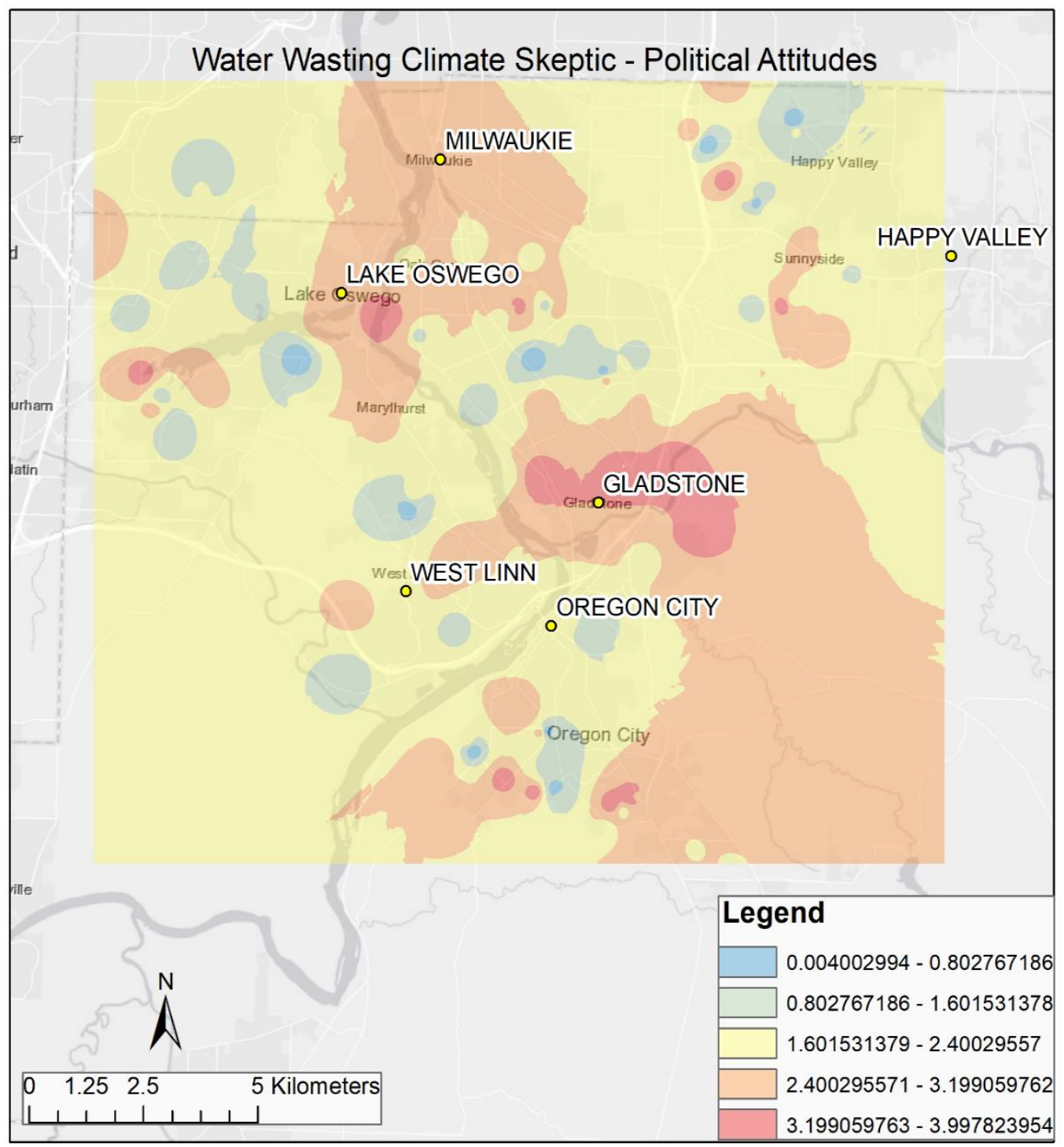

Figure 3-8. GWR coefficients for Political Attitudes. 


\section{Discussion and Conclusion}

Population increase and global climate change pose serious concerns to the future provision of water resources. Policy-makers must balance the threat of diminished provision with increasing demand. These seemingly insurmountable challenges have prompted policy-makers to identify, design, and promote initiatives to not only conserve water, but also protect it at its source (Heejun Chang et al., 2017; Ibrahim et al., 2018; Larson, Polsky, Gober, Chang, \& Shandas, 2013; X. J. Wang et al., 2018).

Researchers and policy-makers in the water resource field have a keen interest in protecting and conserving water must develop an in-depth understanding of the attitudes and subsequent behaviors of water customers. Attitudes and their outward manifestation as behavior posited by (Schwartz, 2017) indicate that behaviors are a byproduct of beliefs about the consequences of actions and attitudes towards personal responsibility for pursuing a given action.

\section{Social Marketing}

In order to develop water protection and conservation programs, researchers and policy makers must engage with the population to better understand these attitudes to design outreach and education programs to target and influence the behavior of water customers. This engagement will require social marketing campaigns. This approach utilizes commercial marketing techniques to promote an idea or behavior that benefits both individuals and society (Domegan et al., 2016; Geller, 1989; Monroe, 2003). Previous studies have found social marketing interventions to cause significant reductions in household water consumption (Lede \& Meleady, 2019; Lowe et al., 2015), 
particularly those which emphasize social normative and social identity message framing in favor of mere conservation education (Seyranian et al., 2015).

\section{Water Customer Segmentation}

The first step in a social marketing campaign is to identify unique segments of the population that demonstrate heterogeneity in their attitudes towards water protection and conservation (Maibach et al., 2011). The novel contribution of this research is the spatial investigation of water customers segmented by attitudes. Our results demonstrated that two fairly

distinct water customer types (Water conscious green progressives, Water wasting climate skeptics) emerged as a byproduct of our segmentation analysis. As the name suggests, factors which were most important in causing segmentation and fostering a narrative typology were attitudes towards climate change impacts, water conservation, and trust. Recent studies on water customer segments have shown water customers to segment into similar categories of conservation attitudes and knowledge of water saving practices such as water savvy conservations, water conscious, unconcerned water users, and careless water users (Ibrahim et al., 2018; Laura Anne Warner et al., 2017). When water customer types were joined to water use data for a subset of respondents in our survey, no statistically significant difference in water use at the $95 \%$ confidence level between customer types was evident. This suggests that while attitudes are important, they may not be principally responsible for reducing water consumption. Factors potentially influencing higher consumption are property size, affluence, and the presence of water efficient appliances.

\section{Implications for Water Managers}


Water conservation and climate impact attitudes pose interesting implications for water managers as both have served as highly significant predictors of source water protection and water conservation in the previous chapters. Water conscious green progressives maintained $35 \%$ low place attitudes, while Water wasting climate skeptics had 53\% low place attitudes, indicating that neither group had a strong affinity or connection to the watershed. The importance of the aforementioned attitudes in predicting support for watershed protection, water conservation, and their utility in defining water customer segments represents a unique entry point for water managers. Income, education, and political attitudes are not subject to manipulation in the way that place attitudes can be (Nielsen-Pincus et al., 2017). Water managers may seek to highlight the importance of the watershed and promote the ample recreation opportunities within the watershed to foster a sense of attachment among their customers, which may result in more desirable watershed protection and conservation behavior. Previous studies on watershed protection and place attachment have suggested that a strong correlation between sense of place and recreational use attitudes exists and water managers should encourage behaviors such as outdoor recreation to develop strong place attitudes among water customers (Nielsen-Pincus et al., 2017). Trust in water management organizations also offers another unique opportunity for influence on behalf of water managers. Previous studies (B. Jorgensen, Graymore, \& Toole, 2009) have identified trust in water managers to effectively manage water, and in the community to be water conscious, as a critical factor in promoting effective water conservation programs. Trust was a significant demarcating variable among segments with Water conscious green progressives exhibiting 33\% low trust in water management organizations compared to $84 \%$ low trust in Water wasting climate skeptics. Perhaps outreach programs designed to foster trust and build community relationships would serve 
as an important step in promoting the sustained effectiveness of protection and conservation programs.

Spatial Patterns of Customer Types

The two customer types demonstrated some overlap in spatial clustering within the water service provider boundary, however some marked spatial patterns are evident. Water conscious green progressives showed a significantly high clustering in Lake Oswego and Happy Valley, while Water wasting climate skeptics cluster in Milwaukie and Lake Oswego. The spatial clustering of water conscious green progressives and water wasting climate skeptics have important implications for water managers in targeting water conservation campaigns and presents opportunities for future research. Previous researchers have argued that affluent households use more water due to larger lot and home size coupled with the relatively negligible cost of water (Seyranian et al., 2015; Willis et al., 2011a). Future research should examine the water consumption of water customer segments with higher positive conservation attitudes to determine if attitudes result in water conservation behavior. Water managers could then identify affluent neighborhoods within the water conscious segment to target social normative messaging around water conservation to bring attitudes in line with desired behavior (Seyranian et al., 2015). Results from our spatial model show the influence of political attitudes on climate impact beliefs, with more liberal attitudes occurring within more affluent regions of the study area underscoring our previous claim that water managers should target affluent neighborhoods for water conservation programs. 


\section{Chapter 4: General Conclusions}

Population growth and climate change pose severe adverse impacts to water resources around the globe. Policy-makers are increasingly concerned with securing future water sources and managing water demand. In the face of these challenges, sustainability of fresh water resources are an increasing concern in many regions of the world and have prompted initiatives designed to conserve water, and protect it at the source (Guhathakurta \& Gober, 2007). Locally, within the Portland, Oregon Metro region (PMA), we are faced with some of the most rapid urbanization rates in the nation at $1.77 \%$ per year (Metro, 2017). The Clackamas River Basin (CRB) also shares some common concerns with other watersheds in the PNW facing similar challenges of climate change and population growth such as the Tualatin and Yamhill Basins in the Willamette Valley (Hoyer \& Chang, 2014).

An important step in protecting these vital resources is developing unique and innovative watershed protection and water conservation programs. Source Water Protection Programs (SWPP) are partnerships between drinking water consumers, public water utilities, and upstream landowners that reduce risks to water quality/quantity from development and non-point sources (e.g., agriculture, forestry, roads). SWPP's offer water resource managers and utilities additional avenues of risk management associated with climate-driven water resource uncertainty. In addition to efforts to protecting water at the source, creative solutions to water demand management (e.g. water conservation programs) that do not involve top-down, policy driven solutions such as tiered-water pricing, curtailments and fines. By looking at watershed protection and water conservation we take a more holistic watershed-wide approach, from the headwaters to the faucet. By taking a 
watershed-wide approach to management, a larger group of stakeholders are incorporated into watershed protection and water conservation initiatives. Laying the foundation of effective SWPP and water conservation programs is understanding the attitudes, motivations, and behaviors of drinking water customers.

Willingness to Pay (WTP) is often a common metric of support in non-market valuations studies. We assessed water customer attitudes towards WTP for a SWPP. Respondents were asked what price ranging from $\$ 0.01, \$ 0.50, \$ 1.00, \$ 3.00, \$ 5.00$, and $\$ 10.00$ they would be WTP for water quality improvement activities over three interventions scenarios: private land, public land, or would rather monies be invested into existing water treatment infrastructure upgrades. We found that when controlling for all other variables save price, perceived climate impacts were the most significant predictor of WTP and respondents did not exhibit a preference for where these water quality interventions would occur. We posited that place attitudes would be a significant predictor of WTP as this has been demonstrated by similar SWPP studies conducted in Oregon (Lurie et al., 2013a). We found that sense of place was not a significant predictor of WTP and this finding could be ascribed to sampling variability, lack of knowledge of customers' water source, and lack of visitation and recreational activities in the watershed. The importance of climate beliefs and concern over climate impacts and support for SWPP is an important lesson from this study. Previous research in the Portland, Oregon area has found concern over climate change to be a significant predictor of changed behavior and climate mitigation strategies, and our research further substantiates these findings (Semenza et al., 2008). Concern over climate change had an produced a $76 \%$ increase in WTP as respondents moved from less concerned to more concerned about the effects of climate change on their local watershed. This strong relationship between climate change 
concern and WTP has interesting implications for outreach and education programs. Underscoring the potential fragility and dire need for water system resilience in the face of urban growth and climate change may be a useful tool for water managers.

In addition to protecting water at the source, demand management programs focusing on water conservation are also an important undertaking for researchers and policy-makers. Water conservation attitudes can have demonstrated outcomes on water use behavior. Many studies and water conservation programs focus on attitudes since they can be subject to manipulation through outreach programs in ways that structural and policy components of water conservation cannot. Water conservation decisions are partially explained by attitude theory, which proposes that specific attitudes influence intentions to engage in a specific behavior, intentions are precursors to planned behavior (Ajzen, 1991; Nielsen-Pincus et al., 2017). Previous studies have demonstrated that prowater conservation decisions are a result of a causal chain of attitudes and behaviors (Straus et al., 2016).

In Chapter 2, we sought to determine if water conservation attitudes and climate impact attitudes served as good predictors of reduced water consumption (e.g. seasonal water variation). We found that pro-water conservation attitudes and climate impact attitudes together, did not serve as good predictors of water savings. Pro-water conservation attitudes, with the presence of water efficient appliances in the home as an intermediary variable, were significant in predicting an increase in seasonal water variation. The results from our path model show that a 1,000 square meter increase in property size results in an estimated reduced water savings of 243 liters/day per household. Modeled water conservation attitudes and resultant water savings follow a causal chain of attitudes and behaviors. Strong pro-conservation attitudes, and the presence of water efficient 
appliance in the home result in a predicted increase of seasonal water variation by 183 liters/day per household.

The significance of the intermediary variable in our study, water efficient appliances, offers yet another entry point for water managers to exert influence on water conservation outcomes. Climate and pro-water conservation attitudes may be difficult to influence, given the highly politicized nature of both topics. A focus on influencing attitudes cannot be entirely discounted since they present a softer approach to "harder" demand management strategies such as curtailment, taxes, or increased fee structures during periods of peak demand(Landon et al., 2018; Lowe et al., 2015; Seyranian et al., 2015; Willis, R.M. Stewart, R.A. Giurco, D.P. Talebpour, M.R. and Mousavinejad, 2011). Attitudes are subject to influence through a variety of outreach and education campaigns that can target various audience segments. However, results from our path model show that attitudes alone are not the only drivers of reduced water consumption. The issue of increased consumption with the presence of water efficient appliances could be attributed to the Jevon's Paradox, which postulates that energy (or water) efficiency gains in household appliances tend to increase overall consumption. A similar phenomenon has been found with hybrid fuel efficient vehicles; a fuel-efficient vehicle enables an individual to drive more. This is known as the rebound effect (Alcott, 2005). Previous studies have shown that water efficient appliances can result in offsetting behavior, which prompts increased water use as the perception of efficiency motivates increased use (Fielding et al., 2012; Seyranian et al., 2015)

In order to operationalize the lessons learned from Chapters $1 \& 2$, researchers and policymakers must engage in social marketing campaigns to "nudge" water customers in a more environmentally desirable, water sustainable direction. The first step in a social marketing campaign 
is to identify unique segments of the population that demonstrate heterogeneity in their attitudes towards water protection and conservation (Maibach et al., 2011). Segmentation is performed in a variety of contexts from traditional marketing of consumer products, public health, and environmental awareness. We sought to segment water customers into heterogenous water customer types, to determine if meaningful narrative typologies could be generated in Chapter 3 . We found that two relatively distinct water customer types emerged: 1) Water conscious green progressives, 2) Water wasting climate skeptics. Water conscious green progressives held strong beliefs about climate impacts, and the other customer type did not. Water wasting climate skeptics, held very low trust in organizations and institutions tasked with water protection and conservation. We sought to validate our customer types by investigating if there were significant differences in water consumption behavior between customer types. Results from our Two Sample T-test showed no significant difference in mean water consumption between customer types. This further elucidates the complexities of water consumption indicating that attitudes, while important factors, are not always the leading factor in predicting reduced water consumption. We attempted to map these theoretical customer types onto existing survey respondents to visually and geostatistically asses if these customer types exhibited any spatial patterns such as clustering. Both customer types exhibited unique spatial patterns of clustering with water conscious green progressives more prominent in the affluent urban neighborhood of Lake Oswego and Happy Valley, and water wasting climate skeptics more prominent in Oregon City, Gladstone, and Milwaukie. While tight clustering of heterogenous customer types allows for more targeted outreach and traditional social marketing campaigns (e.g. mailing, flyers, billboards), there is a variety of new digital mediums that can be targeted at different audience segments that is not spatially dependent. It also allows the 
opportunity for neighbors to influence one another in more pro-environmental directions. Water managers can find ways of rewarding customers that exhibit pro-environmental behavior, crafting social normative messages around water use and water protection. This approach has been widely used in many environmental campaigns ranging from energy conservation (Nolan, Schultz, Cialdini, Goldstein, \& Griskevicius, 2008; Schultz, Nolan, Cialdini, Goldstein, \& Griskevicius, 2018) to water conservation (Ferraro, Messer, \& Wu, 2017; Lede \& Meleady, 2019; Schultz et al., 2014). Researchers found the most effective methods for promoting water conservation are conservation messages that utilize descriptive and aligned norms, displaying a respondent's water usage in relation to their neighborhood accompanied by a "happy" or "sad" face in messaging materials (Schultz et al., 2014).

\section{Hypothetical Program Design Suggestions}

\section{1) Opt-out Program for Source Water Protection}

Ratepayers were automatically enrolled in contributing $\$ 1 /$ month to watershed protection in favor of a "check a box" option to pay on a monthly water utility bill. Automatic enrollment or "opt-out" programs have gained ample research attention and applied success from economists and psychologists for important programs such as organ donation and company $401 \mathrm{k}$ retirement plans. The guiding principle behind these programs is that people tend to follow the default in a variety of 
domains. Policymakers therefore have a broad range of control with important outcomes when deciding what a default option should be (Johnson \& Goldstein, 2004; Madarin \& Shea, 1997; McKenzie, Liersch, \& Finkelstein, 2006). Opt-out programs have been employed in environmental campaigns ranging from the uptake of green bonds to agricultural programs within the U.S. aimed at improving water security (Ebeling \& Lotz, 2015; Ferraro et al., 2017). Opt-out programs represent a "nudge", a minor change to the decision environment which encourage but do not force behavioral change. Nudges consist of minor changes in how decision are presented to decision makers. They are often low-cost, not disruptive to existing programs, and preserve choice (Ferraro et al., 2017). Perhaps constructing a SWPP around opt-out principles would result in greater participation and fundraising, which may improve the efficacy and sustainability of SWPP.

\section{2) Rebates for water efficient appliances}

Initiate a rebate program for the installation of EPA Water Sense or Energy Star high efficiency toilets and washing machines with direct compensation or fee reduction on utility bills. A rebate program was piloted in Miami-Dade County, Florida over the span of four years. The program resulted in approximately a 6-14\% reduction in water consumption for the first two years of the study, with water savings continuing at lower levels during the remainder of the study period (Lee et al., 2011). Portland Water Bureau, Tualatin Valley Water District, and Clackamas River Water Providers all offer some form of rebate program for the installation of water efficient appliances within the home (Clackamas River Water Providers., n.d.; Portland Water Bureau, n.d.; Tualatin Valley Water District, n.d.). Rebate programs coupled with monitoring of water use after rebates serve as useful tool for assessing rebate program effectiveness and achievement of water conservation goals. 


\section{3) Lawn placard for water savings or source water protection}

Placards to be placed on lawns or windows for recipients that exhibit desirable watershed protection or water conservation behavior. Visible demonstrations of conservation attitudes and behavior is a social influence technique used by a variety of industry practitioners. This type of normative messaging has been used by San Diego and Sacramento, CA to encourage water conservation in the face of drought. Sacramento employed a placard that appealed to both injunctive and dynamic norms to communicate a changing social norm (City of Sacramento, n.d.). Injunctive norms describe behaviors that are commonly approved of where dynamic norms describe how norms are changing and have been shown to foster a sense of "preconformity" (Lede \& Meleady, 2019; Sparkman \& Walton, 2017). Perhaps placards designed to appeal to injunctive norms of watershed protection and conservation coupled with dynamic norms highlighting the fragility of the watershed in the face of climate change and the need to protect it would serve as a useful tool for water managers. 


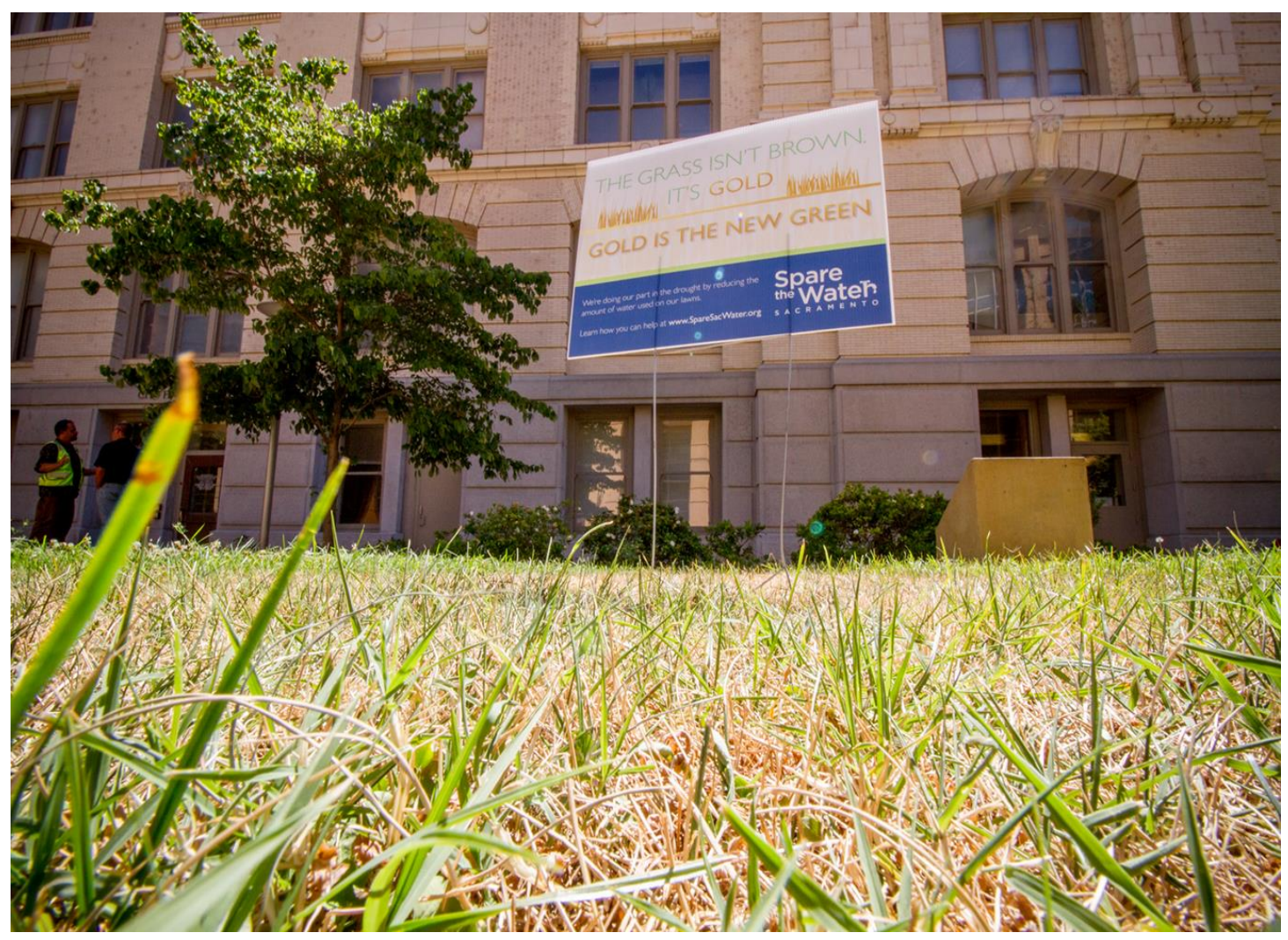

Figure 4-1. Water conservation normative messaging placard utilized by Sacramento, CA.

Water may seem to be the most abundant resource on the planet. However, the diminishing quantity and quality of freshwater due to rapid population growth and climate change pose an existential threat to us all. Policy-makers, researchers, and water consumers must take action to protect and preserve these resources in perpetuity. One step towards achieving this end is a watershed-wide approach to conservation, or forests to faucets. This will require a mixed-mosaic approach of watershed protection, conservation, social marketing, and environmental education. Perhaps the most efficacious use of resources for water protection and conservation begins with children. We should strive to foster a culture of water protection and conservation. Approaches 
must be continually evaluated and modified to fit the unique and changing socio-environmental tapestry of our time. Water is life. 


\section{References}

Ajzen, I. (1991). The theory of planned behavior. Organizational Behavior and Human Decision Processess, 50(2), 179-211.

Akter, S., \& Bennett, J. (2011). Household perceptions of climate change and preferences for mitigation action: The case of the Carbon Pollution Reduction Scheme in Australia. Climatic Change, 109(3-4), 417-436. https://doi.org/10.1007/s10584-011-0034-8

Alcott, B. (2005). Jevons' paradox. Ecological Economics, 54(1), 9-21. https://doi.org/10.1016/j.ecolecon.2005.03.020

Altman, J. A., \& Petkus, E. (1994). Toward a stakeholder-based policy process: An application of the social marketing perspective to environmental policy development. Policy Sciences, 27(1), $37-51$.

Asbjornsen, H., Mayer, A. S., Jones, K. W., Selfa, T., Saenz, L., Kolka, R. K., \& Halvorsen, K. E. (2015). Assessing impacts of payments for watershed services on sustainability in coupled human and natural systems. BioScience, 65(6), 579-591. https://doi.org/10.1093/biosci/biv051

Ashworth, P., Jeanneret, T., Gardner, J., \& Shaw, H. (2011). Communication and climate change: What the Australian public thinks, 68.

Atisa, G., Bhat, M. G., \& McClain, M. E. (2014). Economic Assessment of Best Management Practices in the Mara River Basin: Toward Implementing Payment for Watershed Services. Water Resources Management, 28(6), 1751-1766. https://doi.org/10.1007/s11269-014-05853

Bagstad, K. J., Semmens, D. J., Ancona, Z. H., \& Sherrouse, B. C. (2017). Evaluating alternative methods for biophysical and cultural ecosystem services hotspot mapping in natural resource planning. Landscape Ecology, 32(1), 77-97. https://doi.org/10.1007/s10980-016-0430-6

Bamberg, S., \& Möser, G. (2007). Twenty years after Hines, Hungerford, and Tomera: A new meta-analysis of psycho-social determinants of pro-environmental behaviour. Journal of Environmental Psychology, 27(1), 14-25. https://doi.org/10.1016/j.jenvp.2006.12.002

Bennett, D. E., Gosnell, H., Lurie, S., \& Duncan, S. (2014a). Utility engagement with payments for watershed services in the United States. Ecosystem Services, 8, 56-64.

https://doi.org/10.1016/j.ecoser.2014.02.001

Bennett, D. E., Gosnell, H., Lurie, S., \& Duncan, S. (2014b). Utility engagement with payments for watershed services in the United States. Ecosystem Services, 8, 56-64. https://doi.org/10.1016/j.ecoser.2014.02.001

Bennett, G., \& Ruef, F. (2016). Alliances for Green Infrastructure: State of Watershed Investment 2016, 76. Retrieved from http://www.forest-trends.org/documents/files/doc_5463.pdf 
Brandes, O. M., \& Kriwoken, L. (2006). Changing Perspectives - Changing Paradigms: Taking the " Soft Path " to Water Sustainability in the Okanagan Basin. Canadian Water Resources Journal, 31(2), 75-90. https://doi.org/10.4296/cwrj3102075

Brelsford, C., \& Abbott, J. K. (2017). Growing into Water Conservation? Decomposing the Drivers of Reduced Water Consumption in Las Vegas, NV. Ecological Economics, 133, 99-110. https://doi.org/10.1016/j.ecolecon.2016.10.012

Brock, G., Pihur, V., Datta, S., \& Datta, S. (2015). clValid: An R Package for Cluster Validation . Journal of Statistical Software, 25(4), 1-32. https://doi.org/10.18637/jss.v025.i04

Brouwer, R., Tesfaye, A., \& Pauw, P. (2011). Meta-analysis of institutional-economic factors explaining the environmental performance of payments for watershed services. Environmental Conservation, 38(4), 380-392. https://doi.org/10.1017/S0376892911000543

Browne, A. L., Pullinger, M., Anderson, B., \& Medd, W. (2013). The Performance of Practice :, (May), 1-24.

Brownlee, M. T. J., Hallo, J. C., Moore, D. W. D., Powell, R. B., \& Wright, B. A. (2014). Attitudes toward Water Conservation: The Influence of Site-Specific Factors and Beliefs in Climate Change. Society and Natural Resources, 27(9), 964-982. https://doi.org/10.1080/08941920.2014.929768

Campbell, H. E., Johnson, R. M., \& Larson, E. H. (2004). Prices, devices, people, or rules: The relative effectiveness of policy instruments in water conservation. Review of Policy Research, 21(5), 637-662. https://doi.org/10.1111/j.1541-1338.2004.00099.x

Champ, P. A., Bishop, R. C., Brown, T. C., \& McCollum, D. W. (1997). Using Donation Mechanisms to Value Nonuse B enefits from, 151-162.

Chang, H. (2017). Water Conservation. In International Encyclopedia of Geography (pp. 1-5). American Cancer Society. https://doi.org/10.1002/9781118786352.wbieg0828

Chang, H., Bonnette, M. R., Stoker, P., Crow-Miller, B., \& Wentz, E. (2017). Determinants of single family residential water use across scales in four western US cities. Science of the Total Environment, 596-597, 451-464. https://doi.org/10.1016/j.scitotenv.2017.03.164

Chang, H., Parandvash, G. H., \& Shandas, V. (2010). Spatial variations of single-family residential water consumption in Portland, Oregon. Urban Geography, 31(7), 953-972. https://doi.org/10.2747/0272

Cheryl Dieter, Molly A. Maupin, Rodney R. Caldwell, Melissa A. Harris, Tamara I. Ivahnenko, John K. Lovelace, Nancy L. Barber, and K. S. L. (2015). Estimated use of water in the United States in 1970. US Geological Survey Circular. Retrieved from http://pubs.er.usgs.gov/publication/cir676

Chun, N., Rancik, K., Haggerty, R., \& Ollinger, J. (2018). Coordinated Population Forecast for Jackson County, its Urban Growth Boundaries (UGB), and Area Outside UGBs 2018-2068. Oregon Population Forecast Program, 1-51. 
City of Sacramento. (n.d.). Gold is the New Green campaign makes national news - City Express. Retrieved April 23, 2019, from https://sacramentocityexpress.com/2014/07/17/gold-is-thenew-green-campaign-makes-national-news/

Clackamas River Water Providers. (n.d.). Rebates - Clackamas River Water. Retrieved April 23, 2019, from http://crwater.com/rebates/

Cominola, A., Spang, E. S., Giuliani, M., Castelletti, A., Lund, J. R., \& Loge, F. J. (2018). Segmentation analysis of residential water-electricity demand for customized demand-side management programs. Journal of Cleaner Production, 172, 1607-1619. https://doi.org/10.1016/j.jclepro.2017.10.203

Corral-Verdugo, V., \& Frías-Armenta, M. (2006). Personal normative beliefs, antisocial behavior, and residential water conservation. Environment and Behavior, 38(3), 406-421. https://doi.org/10.1177/0013916505282272

Dias, T. F., Kalbusch, A., \& Henning, E. (2018). Factors influencing water consumption in buildings in southern Brazil. Journal of Cleaner Production, 184, 160-167. https://doi.org/10.1016/j.jclepro.2018.02.093

Dietz, T., Dan, A., \& Shwom, R. (2007). Support for Climate Change Policy : Social Psychological and Social Structural Influences. Rural Sociology, 72(2), 185-214. https://doi.org/10.1526/003601107781170026

Dolnicar, S., \& Hurlimann, A. (2010). Australians' water conservation behaviours and attitudes. Australian Journal of Water Resources, 14(1), 43-53. https://doi.org/10.1080/13241583.2010.11465373

Domegan, C., McHugh, P., Devaney, M., Duane, S., Hogan, M., Broome, B. J., .. Piwowarczyk, J. (2016). Systems-thinking social marketing: conceptual extensions and empirical investigations. Journal of Marketing Management, 32(11-12), 1123-1144. https://doi.org/10.1080/0267257X.2016.1183697

Drinking Water Infrastructure Report Card. (n.d.). Water Infrastructure | ASCE's 2017 Infrastructure Report Card. Retrieved September 14, 2018, from https://www.infrastructurereportcard.org/cat-item/drinking-water/

Ebeling, F., \& Lotz, S. (2015). Domestic uptake of green energy promoted by opt-out tariffs. Nature Climate Change, 5(9), 868-871. https://doi.org/10.1038/nclimate2681

Ferraro, P., Messer, K. D., \& Wu, S. (2017). Applying Behavioral Insights to Improve Water Security. Choices, Volume 32(4), 1-6. Retrieved from http://ageconsearch.umn.edu/record/264602/files/cmsarticle_602.pdf\%0Ahttp://ageconsearch. umn.edu/record/264602/files/cmsarticle_602.pdf?subformat=pdfa\%0Ahttp://ageconsearch.u mn.edu/record/264602/files/cmsarticle_602.pdf?subformat=pdfa LK - http://agecons

Fielding, K. S., Russell, S., Spinks, A., \& Mankad, A. (2012). Determinants of household water conservation: The role of demographic , infrastructure, behavior, and psychosocial variables, 48(May). https://doi.org/10.1029/2012WR012398 
García de Jalón, S., Iglesias, A., Quiroga, S., \& Bardají, I. (2013). Exploring public support for climate change adaptation policies in the Mediterranean region: A case study in Southern Spain. Environmental Science and Policy, 29, 1-11. https://doi.org/10.1016/j.envsci.2013.01.010

Gartner, Todd, Kara Di Francesco, Suzanne Ozment, Heidi Huber-Stearns, Nathaniel Lichten, and S. T. (2016). Protecting Drinking Water Sources.

Gartner, T., Di Francesco, K., Ozment, S., Huber-Stearns, H., Lichten, N., \& Tognetti, S. (2017). Protecting drinking water at the source: lessons from US watershed investment programs. Journal-American Water Works Association, 109(4), 30-41.

Geller, E. S. (1989). Applied Behavior Analysis and Social Marketing - an Integration for Environmental Preservation. Journal of Social Issues, 45(1), 17-36. https://doi.org/10.1111/j.1540-4560.1989.tb01531.x

Ghavidelfar, S., Shamseldin, A. Y., \& Melville, B. W. (2017). A Multi-Scale Analysis of SingleUnit Housing Water Demand Through Integration of Water Consumption, Land Use and Demographic Data. Water Resources Management, 31(7), 2173-2186. https://doi.org/10.1007/s11269-017-1635-4

Gordon, A. D. (1999). Classification. Chapman \& Hall/CRC. Retrieved from https://books.google.com/books/about/Classification_2nd_Edition.html?id=_w5AJtbfEz4C

Grima, N., Singh, S. J., Smetschka, B., \& Ringhofer, L. (2016). Payment for Ecosystem Services (PES) in Latin America: Analysing the performance of 40 case studies. Ecosystem Services, 17, 24-32. https://doi.org/10.1016/j.ecoser.2015.11.010

Guhathakurta, S., \& Gober, P. (2007). The Impact of the Phoenix Urban Heat Island on Residential Water Use. Journal of the American Planning Association, 73(3), 317-329. https://doi.org/10.1080/01944360708977980

Guhathakurta, S., \& Gober, P. (2010). Residential land use, the urban heat island, and water use in Phoenix: A path analysis. Journal of Planning Education and Research, 30(1), 40-51. https://doi.org/10.1177/0739456X10374187

Halkidi, M., Batistakis, Y., \& Vazirgiannis, M. (2002). Cluster Validity M e t h o d s : Part I, 31(2), 40-45.

Hayden, L., Cadenasso, M. L., Haver, D., \& Oki, L. R. (2015). Residential landscape aesthetics and water conservation best management practices: Homeowner perceptions and preferences. Landscape and Urban Planning, 144, 1-9. https://doi.org/10.1016/j.landurbplan.2015.08.003

Hong, C.-Y., \& Chang, H. (2014). Uncovering the influence of household sociodemographic and behavioral characteristics on summer water consumption in the Portland metropolitan area.

International Journal of Geospatial and Environmental Research, 1(2), 1-23. Retrieved from http://dc.uwm.edu/ijger\%5Cnhttp://dc.uwm.edu/ijger/vol1/iss2/2

House-Peters, L. A., \& Chang, H. (2011). Urban water demand modeling: Review of concepts, methods, and organizing principles. Water Resources Research, 47(5). 
https://doi.org/10.1029/2010WR009624

House-Peters, L., Pratt, B., \& Chang, H. (2010). Effects of urban spatial structure, sociodemographics, and climate on residential water consumption in Hillsboro, Oregon. Journal of the American Water Resources Association (JAWRA), 46(3), 461-472. https://doi.org/10.1111

Hoyer, R., \& Chang, H. (2014). Development of Future Land Cover Change Scenarios in the Metropolitan Fringe, Oregon, U.S., with Stakeholder Involvement. Land, 3, 322-341. https://doi.org/10.3390/land3010322

Hu, L. T., \& Bentler, P. M. (1999). Cutoff criteria for fit indexes in covariance structure analysis: Conventional criteria versus new alternatives. Structural Equation Modeling, 6(1), 1-55. https://doi.org/10.1080/10705519909540118

Hunter, P. D., Hanley, N., Mearns, K., Tyler, A. N., Carvalho, L., \& Codd, G. A. (2012). Science of the Total Environment The effect of risk perception on public preferences and willingness to pay for reductions in the health risks posed by toxic cyanobacterial blooms, 426, 32-44. https://doi.org/10.1016/j.scitotenv.2012.02.017

Ibrahim, A., Knox, K., Rundle-Thiele, S., \& Arli, D. (2018). Segmenting a Water Use Market: Theory of Interpersonal Behavior Insights. Social Marketing Quarterly, 24(1), 3-17. https://doi.org/10.1177/1524500417741277

Johnson, E. J., \& Goldstein, D. G. (2004). Defaults and donation decisions. Transplantation, 78(12), 1713-1716. https://doi.org/10.1097/01.TP.0000149788.10382.B2

Jorgensen, B., Graymore, M., \& Toole, K. O. (2009). Household water use behavior: An integrated model, 91, 227-236. https://doi.org/10.1016/j.jenvman.2009.08.009

Jorgensen, B. S., Martin, J. F., Pearce, M. W., \& Willis, E. M. (2014). Predicting Household Water Consumption With Individual-Level Variables. Environment and Behavior, 46(7), 872-897. https://doi.org/10.1177/0013916513482462

Jung, I.-W., Moradkhani, H., \& Chang, H. (2012). Uncertainty assessment of climate change impacts for hydrologically distinct river basins. Journal of Hydrology, 466-467(October), 73 87. https://doi.org/10.1016/j.jhydrol.2012.08.002

Karimi, A., Brown, G., \& Hockings, M. (2015). Methods and participatory approaches for identifying social-ecological hotspots. Applied Geography, 63, 9-20. https://doi.org/10.1016/j.apgeog.2015.06.003

Kondolf, G. M., Anderson, S., Lave, R., Pagano, L., Merenlender, a., \& Bernhardt, E. S. (2007). Two decades of river restoration in California: What can we learn? Restoration Ecology, 15(3), 516-523. https://doi.org/10.1111/j.1526-100X.2007.00247.x

Kramer, R. A., \& Mercer, D. E. (2019). Valuing a Global Environmental Good : U . S . Residents ' Willingness to Pay to Protect Tropical Rain Forests Author ( s ): Randall A . Kramer and D. Evan Mercer Published by: University of Wisconsin Press Stable URL: https://www.jstor.org/stable/31472, 73(2), 196-210. 
Lalika, M. C. S., Meire, P., Ngaga, Y. M., \& Sanga, G. J. (2017). Willingness to pay for watershed conservation: are we applying the right paradigm? Ecohydrology and Hydrobiology, 17(1), 33-45. https://doi.org/10.1016/j.ecohyd.2016.12.004

Landon, A. C., Woodward, R. T., Kyle, G. T., \& Kaiser, R. A. (2018). Evaluating the efficacy of an information-based residential outdoor water conservation program. Journal of Cleaner Production, 195, 56-65. https://doi.org/10.1016/j.jclepro.2018.05.196

Langfelder, P., Zhang, B., \& Horvath, S. (2008). Defining clusters from a hierarchical cluster tree: The Dynamic Tree Cut package for R. Bioinformatics, 24(5), 719-720. https://doi.org/10.1093/bioinformatics/btm563

Larson, K. L., Polsky, C., Gober, P., Chang, H., \& Shandas, V. (2013). Vulnerability of water systems to the effects of climate change and urbanization: A comparison of phoenix, Arizona and Portland, Oregon (USA). Environmental Management, 52(1), 179-195. https://doi.org/10.1007/s00267-013-0072-2

Lede, E., \& Meleady, R. (2019). Applying social influence insights to encourage climate resilient domestic water behavior: Bridging the theory-practice gap. Wiley Interdisciplinary Reviews: Climate Change, 10(1), 1-13. https://doi.org/10.1002/wcc.562

Lee, M., Tansel, B., \& Balbin, M. (2011). Influence of residential water use efficiency measures on household water demand: A four year longitudinal study, 56, 1-6.

https://doi.org/10.1016/j.resconrec.2011.08.006

Leiserowitz, a. (2012). Climate Change in the American Mind. Americans' Global Warming Beliefts and Attitudes in March 2012, (March), 19. Retrieved from http://webdev.p2061.org/events/meetings/climate2010/includes/media/presentations/Leiserow itz_AAAS-NSF2.pdf

Lin, S., Van Poucke, S., Zhang, Z., Lan, P., \& Murtagh, F. (2017). Hierarchical cluster analysis in clinical research with heterogeneous study population: highlighting its visualization with $\mathrm{R}$. Annals of Translational Medicine, 5(4), 75-75. https://doi.org/10.21037/atm.2017.02.05

Lowe, B., Lynch, D., \& Lowe, J. (2014). The role and application of social marketing in managing water consumption: a case study. International Journal of Nonprofit and Voluntary Sector Marketing, 21(February), 14-26. https://doi.org/10.1002/nvsm

Lowe, B., Lynch, D., \& Lowe, J. (2015). Reducing household water consumption: a social marketing approach. Journal of Marketing Management, 31(3-4), 378-408. https://doi.org/10.1080/0267257X.2014.971044

Lurie, S., Bennett, D. E., Duncan, S., Gosnell, H., Hunter, M. L., Morzillo, A. T., ... White, E. M. (2013a). PES marketplace development at the local scale: The Eugene Water and Electric Board as a local watershed services marketplace driver. Ecosystem Services, 6, 93-103. https://doi.org/10.1016/j.ecoser.2013.09.005

Lurie, S., Bennett, D. E., Duncan, S., Gosnell, H., Hunter, M. L., Morzillo, A. T., ... White, E. M. (2013b). PES marketplace development at the local scale: The Eugene Water and Electric 
Board as a local watershed services marketplace driver. Ecosystem Services, 6, 93-103. https://doi.org/10.1016/j.ecoser.2013.09.005

Madarin, B., \& Shea, D. (1997). Quarterly journal of economics, CXII(August), 1149-1187.

Maibach, E. W., Leiserowitz, A., Roser-Renouf, C., \& Mertz, C. K. (2011). Identifying like-minded audiences for global warming public engagement campaigns: An audience segmentation analysis and tool development. PLoS ONE, 6(3).

https://doi.org/10.1371/journal.pone.0017571

Manne, A., \& Richels, R. (2005). MERGE: an integrated assessment model for global climate change. Energy and Environment, (June), 175-189. https://doi.org/10.1007/0-387-25352-1_7

Mckenzie-Mohr, D. (2000). Promoting Sustainable Behavior: An Introduction to CommunityBased Social Marketing. Journal of Social Issues, 56(3), 543-554. https://doi.org/10.1111/0022-4537.00183

McKenzie, C. R. M., Liersch, M. J., \& Finkelstein, S. R. (2006). Recommendations implicit in policy defaults. Psychological Science, 17(5), 414-420. https://doi.org/10.1111/j.14679280.2006.01721.x

Metcalf, A. L., Gruver, J. B., Finley, J. C., \& Luloff, A. E. (2015). Segmentation to Focus Outreach: Behavioral Intentions of Private Forest Landowners in Pennsylvania. Journal of Forestry, 114(4), 466-473. https://doi.org/10.5849/jof.15-030

Monroe, M. (2003). Two Avenues for Encouraging Conservations Behaviors. Human Ecology Review, 10(2), 113-125. https://doi.org/10.1177/1086026601141001

Myers, N. (2016). Community-Based Social Marketing: Tools for reducing demand through behavior change, 1-5. Retrieved from http://efc.web.unc.edu/2016/07/01/community-basedsocial-marketing/

Newell, M. A., Cook, D., Hofmann, H., \& Jannink, J. L. (2013). An algorithm for deciding the number of clusters and validation using simulated data with application to exploring crop population structure. Annals of Applied Statistics, 7(4), 1898-1916. https://doi.org/10.1214/13AOAS671

Nielsen-Pincus, M., Ribe, R. G., \& Johnson, B. R. (2015). Spatially and socially segmenting private landowner motivations, properties, and management: A typology for the wildland urban interface. Landscape and Urban Planning, 137(May), 1-12. https://doi.org/10.1016/j.landurbplan.2014.11.020

Nielsen-Pincus, M., Sussman, P., Bennett, D. E., Gosnell, H., \& Parker, R. (2017). The Influence of Place on the Willingness to Pay for Ecosystem Services. Society \& Natural Resources, O(0), 1-19. https://doi.org/10.1080/08941920.2017.1347976

NOAA. (n.d.). Climate at a Glance | National Centers for Environmental Information (NCEI). Retrieved February 13, 2019, from https://www.ncdc.noaa.gov/cag/city/timeseries/USW00024229/tavg/3/8/19872019?base_prd=true\&firstbaseyear $=1938 \&$ lastbaseyear $=2000$ 
Nolan, J. M., Schultz, P. W., Cialdini, R. B., Goldstein, N. J., \& Griskevicius, V. (2008). Normative social influence is underdetected. Personality and Social Psychology Bulletin, 34(7), 913-923. https://doi.org/10.1177/0146167208316691

Obeng, E. A., \& Aguilar, F. X. (2018). Value orientation and payment for ecosystem services: Perceived detrimental consequences lead to willingness-to-pay for ecosystem services. Journal of Environmental Management, 206, 458-471. https://doi.org/10.1016/j.jenvman.2017.10.059

Ojeda, A., Álvarez, C. R., Ramos, M., \& Soto, F. (2016). Determinants of domestic water consumption in Hermosillo, Sonora, Mexico. Journal of Cleaner Production, 142, 19011910. https://doi.org/10.1016/j.jclepro.2016.11.094

Paneque, P., Lafuente, R., \& Vargas, J. (2018). Public attitudes toward water management measures and droughts: A study in Southern Spain. Water (Switzerland), 10(4). https://doi.org/10.3390/w10040369

Pindyck, R. S. (2012). Uncertain outcomes and climate change policy. Journal of Environmental Economics and Management, 63(3), 289-303. https://doi.org/10.1016/j.jeem.2011.12.001

Polsky, C., Grove, J. M., Knudson, C., Groffman, P. M., Bettez, N., Cavender-Bares, J., ... Steele, M. K. (2014). Assessing the homogenization of urban land management with an application to US residential lawn care. Proceedings of the National Academy of Sciences of the United States of America, 111(12), 4432-7. https://doi.org/10.1073/pnas.1323995111

Portland, Oregon Population 2019 (Demographics, Maps, Graphs). (n.d.). Retrieved April 13, 2019, from http://worldpopulationreview.com/us-cities/portland-population/

Portland Water Bureau. (n.d.). Water Efficiency Rebates \&amp; Incentives | The City of Portland, Oregon. Retrieved April 23, 2019, from https://www.portlandoregon.gov/water/59348

Quesnel, K. J., \& Ajami, N. K. (2017). Changes in water consumption linked to heavy news media coverage of extreme climatic events. Science Advances, 3(10), 1-10. https://doi.org/10.1126/sciadv.1700784

Revelle, W. (2013). An overview of the psych package. R Package Version, 99. https://doi.org/10.1109/TEM.2010.2048913

Rosseel, Y. (2010). lavaan: an R package for structural equation modeling and more, 48(2).

S. Jones, L. Rees, Danika Hall, A. T. (2005). Using market segmentation theory to select target markets for sun protection campaigns. Faculty of Health and Behavioural Sciences, 413-428. Retrieved from http://dx.doi.org/10.1080/0965254X.2013.801609

Sanchez, G. M., Smith, J. W., Terando, A., Sun, G., \& Meentemeyer, R. K. (2018). Water resources research. Water Resources Research, 54(3), 1633-1649. https://doi.org/10.1002/2014WR016259

Saurí, D. (2013). Water Conservation: Theory and Evidence in Urban Areas of the Developed World. Annual Review of Environment and Resources, 38(1), 227-248. 
https://doi.org/10.1146/annurev-environ-013113-142651

Sausen, K., Tomczak, T., \& Herrmann, A. (2005). Development of a taxonomy of strategic market segmentation: A framework for bridging the implementation gap between normative segmentation and business practice. Journal of Strategic Marketing, 13(3), 151-173. https://doi.org/10.1080/09652540500171340

Schultz, P. W., Messina, A., Tronu, G., Limas, E. F., Gupta, R., \& Estrada, M. (2014). Personalized Normative Feedback and the Moderating Role of Personal Norms. Environment and Behavior, 48(5), 686-710. https://doi.org/10.1177/0013916514553835

Schultz, P. W., Nolan, J. M., Cialdini, R. B., Goldstein, N. J., \& Griskevicius, V. (2018). The Constructive, Destructive, and Reconstructive Power of Social Norms: Reprise. Perspectives on Psychological Science, 13(2), 249-254. https://doi.org/10.1177/1745691617693325

Schwartz, S. H. (2017). Normative Influences on Altruism, (January 1977). Retrieved from https://www.researchgate.net/profile/Shalom_Schwartz/publication/319507233_NORMATI VE_INFLUENCES_ON_ALTRUISM/links/59b005cf458515563dd2faf6/NORMATIVEINFLUENCES-ON-ALTRUISM.pdf

Semenza, J. C., Hall, D. E., Wilson, D. J., Bontempo, B. D., Sailor, D. J., \& George, L. A. (2008). Public Perception of Climate Change. Voluntary Mitigation and Barriers to Behavior Change. American Journal of Preventive Medicine, 35(5), 479-487. https://doi.org/10.1016/j.amepre.2008.08.020

Seyranian, V., Sinatra, G. M., \& Polikoff, M. S. (2015). Comparing communication strategies for reducing residential water consumption. Journal of Environmental Psychology, 41, 81-90. https://doi.org/10.1016/j.jenvp.2014.11.009

Shandas, V., \& Parandvash, G. H. (2010). Integrating urban form and demographics in waterdemand management: An empirical case study of Portland, Oregon. Environment and Planning B: Planning and Design, 37(1), 112-128. https://doi.org/10.1068/b35036

Sharma, P., Kaur, L., Mittal, R., Kaur, S., \& Kaur, S. (2018). Social marketing approach to bring change in water use behaviour of rural people of Punjab, India. https://doi.org/10.2166/wcc.2018.150

Sparkman, G., \& Walton, G. M. (2017). Dynamic Norms Promote Sustainable Behavior, Even if It Is Counternormative. Psychological Science, 28(11), 1663-1674. https://doi.org/10.1177/0956797617719950

Stokowski, P. a. (2002). Languages of place and discourses of power: Constructing new senses of place. Journal of Leisure Research, 34, 368-382. Retrieved from http://search.proquest.com/docview/201199118?pq-origsite=gscholar

Straughan, R. D., \& Roberts, J. A. (1993). Environmental segmentation alternatives: a look at green consumer behavior in the new millennium. Journal of Consumer Marketing Journal of Consumer Marketing Journal of Consumer Marketing Iss Journal of Consumer Marketing, 16(3), 558-575. https://doi.org/10.1108/07363769910297506 
Straus, J., Chang, H., \& Hong, C. Y. (2016). An exploratory path analysis of attitudes, behaviors and summer water consumption in the Portland Metropolitan Area. Sustainable Cities and Society, 23, 68-77. https://doi.org/10.1016/j.scs.2016.03.004

Syme, G. J., Nancarrow, B. E., \& Seligman, C. (2000). The Evaluation of Information Campaigns to Promote Voluntary Household Water Conservation. Evaluation Review, 24(6), 539-578. https://doi.org/10.1177/0193841X0002400601

Tualatin Valley Water District. (n.d.). Tualatin Valley Water District: Request A Rebate. Retrieved April 23, 2019, from https://www.tvwd.org/conservation--rebates/request-a-rebate.aspx

Uchida, E., Swallow, S. K., Gold, A. J., Opaluch, J., Kafle, A., Merrill, N. H., ... Gill, C. A. (2018). Integrating Watershed Hydrology and Economics to Establish a Local Market for Water Quality Improvement: A Field Experiment. Ecological Economics, 146(July 2017), 17-25. https://doi.org/10.1016/j.ecolecon.2017.09.003

Veronesi, M., Chawla, F., Maurer, M., \& Lienert, J. (2013). Working Paper Series Department of Economics University of Verona Climate Change and the Willingness to Pay to Reduce Ecological and Health Risks from Wastewater Flooding in Urban Centers and the Environment, 2919(January).

Villar-Navascués, R. A., \& Pérez-Morales, A. (2018). Factors Affecting Domestic Water Consumption on the Spanish Mediterranean Coastline. Professional Geographer, 70(3), 513525. https://doi.org/10.1080/00330124.2017.1416302

Wang, S., \& Gita Taasoobshirazi. (2016). Quantitative Methods Inquires THE PERFORMANCE OF THE SRMR, RMSEA, CFI, AND TLI : AN EXAMINATION OF SAMPLE SIZE, PATH SIZE , 31-40.

Wang, X. J., Zhang, J. Y., Shahid, S., Xie, W., Du, C. Y., Shang, X. C., \& Zhang, X. (2018). Modeling domestic water demand in Huaihe River Basin of China under climate change and population dynamics. Environment, Development and Sustainability, 20(2), 911-924. https://doi.org/10.1007/s10668-017-9919-7

Warner, L. A., Lamm, A., Chaudhary, A. K., Rumble, J. N., Lamm, A. J., \& Momol, E. (2017). Using Audience Segmentation to Tailor Residential Irrigation Water Conservation Programs Using Audience Segmentation to Tailor Residential Irrigation Water Conservation Programs, (January). https://doi.org/10.5032/jae.2017.01313

Warner, L. A., Lamm, A. J., \& Kumar Chaudhary, A. (2018). Florida residents' perceived role in protecting water quantity and quality through landscape practices. Landscape and Urban Planning, 171(March 2017), 1-6. https://doi.org/10.1016/j.landurbplan.2017.11.007

Warner, L. A., Lamm, A. J., Rumble, J. N., Martin, E. T., \& Cantrell, R. (2016). Classifying Residents who use Landscape Irrigation: Implications for Encouraging Water Conservation Behavior. Environmental Management, 58(2), 238-253. https://doi.org/10.1007/s00267-0160706-2

Welsh, M. P., \& Poe, G. L. (1998). Elicitation effects in contingent valuation: Comparisons to a 
multiple bounded discrete choice approach. Journal of Environmental Economics and Management, 36(2), 170-185. https://doi.org/10.1006/jeem.1998.1043

Wentz, E. A., \& Gober, P. (2007). Determinants of small-area water consumption for the City of Phoenix, Arizona. Water Resources Management, 21(11), 1849-1863. https://doi.org/10.1007/s11269-006-9133-0

Whitmarsh, L. (2008). Are flood victims more concerned about climate change than other people? the role of direct experience in risk perception and behavioural response. Journal of Risk Research, 11(3), 351-374. https://doi.org/10.1080/13669870701552235

Willis, R.M. Stewart, R.A. Giurco, D.P. Talebpour, M.R. and Mousavinejad, A. (2011). (2011). End use water consumption in households : impact of socio-demographic factors and efficient devices. Journal of Cleaner Production. https://doi.org/10.1016/j.jclepro.2011.08.006.End

Willis, R. M., Stewart, R. A., Panuwatwanich, K., Williams, P. R., \& Hollingsworth, A. L. (2011a). Quantifying the influence of environmental and water conservation attitudes on household end use water consumption. Journal of Environmental Management, 92(8), 1996-2009. https://doi.org/10.1016/j.jenvman.2011.03.023

Willis, R. M., Stewart, R. A., Panuwatwanich, K., Williams, P. R., \& Hollingsworth, A. L. (2011b). Quantifying the influence of environmental and water conservation attitudes on household end use water consumption. Journal of Environmental Management, 92(8), 1996-2009. https://doi.org/10.1016/j.jenvman.2011.03.023

Yang, Y., \& Liu, Y. (2014). Spatio-temporal analysis of urbanization and land and water resources efficiency of oasis cities in Tarim River Basin. Journal of Geographical Sciences, 24(3), 509525. https://doi.org/10.1007/s11442-014-1103-5 


\section{Appendix A: Factor Loading for Exploratory Factor Analysis (EFA) Derived Variables}

\section{Sense of Place}

5-1. Factor Loadings and Communality Estimates for Sense of Place Variables

\begin{tabular}{|c|c|c|c|}
\hline Question Items & $\%$ Agree & Factor Loading & Communality Estimates \\
\hline \multicolumn{4}{|l|}{ Place Attachment } \\
\hline It is my favorite place to be & $30 \%$ & 0.82 & 0.67 \\
\hline I feel happiest when I am there & $21 \%$ & 0.85 & 0.72 \\
\hline I really miss it when I am away for too long & $24 \%$ & 0.89 & 0.79 \\
\hline \multicolumn{4}{|l|}{ Place Identity } \\
\hline It reflects the type of person I am & $28 \%$ & 0.77 & 0.59 \\
\hline I feel I can really be myself when I'm there & $29 \%$ & 0.82 & 0.67 \\
\hline I don't really identify with the Clackamas Watershed ${ }^{\mathrm{a}}$ & $30 \%$ & 0.69 & 0.48 \\
\hline \multicolumn{4}{|l|}{ Place Dependence } \\
\hline There are better places to be as far as I am concerned ${ }^{\mathrm{a}}$ & $20 \%$ & 0.52 & 0.27 \\
\hline It is the best place for me to do the outdoor things I enjoy & $35 \%$ & 0.81 & 0.66 \\
\hline \multicolumn{4}{|l|}{ *Cronbach’s Alpha (0.9) } \\
\hline \multicolumn{4}{|l|}{ Eigenvalue of the first factor extracted (4.83) } \\
\hline \multicolumn{4}{|l|}{ Proportion of variance explained $(0.60)$} \\
\hline aReverse coded for analysis & & & \\
\hline
\end{tabular}




\section{Climate Impacts}

Table 5-2. Factor Loadings and Communality Estimates for Climate Impact Attitudes

\begin{tabular}{|c|c|c|c|}
\hline Question Items & $\%$ Agree & Factor Loading & Communality Estimates \\
\hline \multicolumn{4}{|l|}{ Climate change will... } \\
\hline $\begin{array}{l}\text { Threaten water supply due to declines in snowpack (more } \\
\text { winter rain, less winter snow) }\end{array}$ & $45 \%$ & 0.87 & 0.75 \\
\hline $\begin{array}{l}\text { Threaten water supply due to increased demand (people use } \\
\text { more water when it's hot) }\end{array}$ & $40 \%$ & 0.84 & 0.70 \\
\hline $\begin{array}{l}\text { Threaten drinking water quality due to an increase in extreme } \\
\text { storms }\end{array}$ & $26 \%$ & 0.77 & 0.59 \\
\hline Threaten the way I make a living & $4 \%$ & 0.30 & 0.09 \\
\hline Threaten my quality of life & $23 \%$ & 0.84 & 0.71 \\
\hline $\begin{array}{l}\text { Not threaten drinking water because technology will provide } \\
\text { clean water even if climate changes }\end{array}$ & $20 \%$ & 0.58 & 0.33 \\
\hline Improve the way I make a living & $39 \%$ & 0.38 & 0.15 \\
\hline Improve my quality of life ${ }^{a}$ & $42 \%$ & 0.62 & 0.38 \\
\hline \multicolumn{4}{|l|}{ *Cronbach’s Alpha (0.82) } \\
\hline \multicolumn{4}{|l|}{ Eigenvalue of the first factor extracted (3.70) } \\
\hline Proportion of variance explained $(0.46)$ & & & \\
\hline${ }^{\text {aReverse coded for analysis }}$ & & & \\
\hline
\end{tabular}




\section{Appendix B: Survey Materials}

\section{Survey Cover Page}

\section{Page 1- Consent Form}

We are contacting you to ask for your help in a study on drinking water customers desire to participate in ongoing drinking water source protection efforts in the Clackamas River Watershed. This study is being conducted by Daniel Larson and Dr. Max Nielsen-Pincus from the Portland State University Department of Environmental Science and Management in collaboration with the Clackamas River Water Providers (CRWP), a coalition of drinking water utilities operating in the Clackamas River Watershed.

As part of this study, we request that you complete the enclosed questionnaire about your attitudes to participation in a source water protection program. Participation in this study is an opportunity for you to voice your opinions about programs that promote watershed conservation while providing the highest quality drinking water. This research will contribute to a growing body of work regarding the role that public utilities and the private sector can play in strengthening and supporting the environmental and economic benefits of local watersheds. As a thank you for submitting your completed survey, you will be automatically entered into a drawing to receive a $\$ 100$ gift card.

For convenience, we are also offering the questionnaire in a web-based form. If you would prefer to complete the questionnaire online, you may enter the link and four-digit passcode listed below:

$$
\text { http://tinyurl.com/ClackamasRatepayer Passcode: }
$$

Please complete the questionnaire and mail it back to us in the enclosed postage-paid envelope, or complete the web version. Your responses are entirely confidential, and your name will never be connected to your answers. Your decision to take part in this study is completely voluntary, you may skip any questions you do not want to answer, and you have the right to end your participation at any time. When you complete and return the attached questionnaire, it means that you have read and understood this information, and you agree to take part in this study. If you have questions or concerns about your participation in this study or about your rights as a research participant, please contact the Human Subjects Research Review Committee at:

PSU Office of Research Integrity

1600 SW 4th Ave., Market Center Building, Suite 620

Portland, OR 97201

503-725-2227 or $877-480-4400$

Thank you very much for your time and support of this study.

Sincerely,

Daniel Larson

Ph.D. Student

Max Nielsen-Pincus

dlar2@pdx.edu

Assistant Professor

maxnp@pdx.edu

Clackamas River

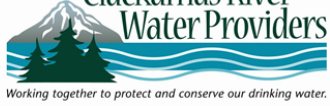


Page 2 - Area Map

\section{The Clackamas River Watershed}

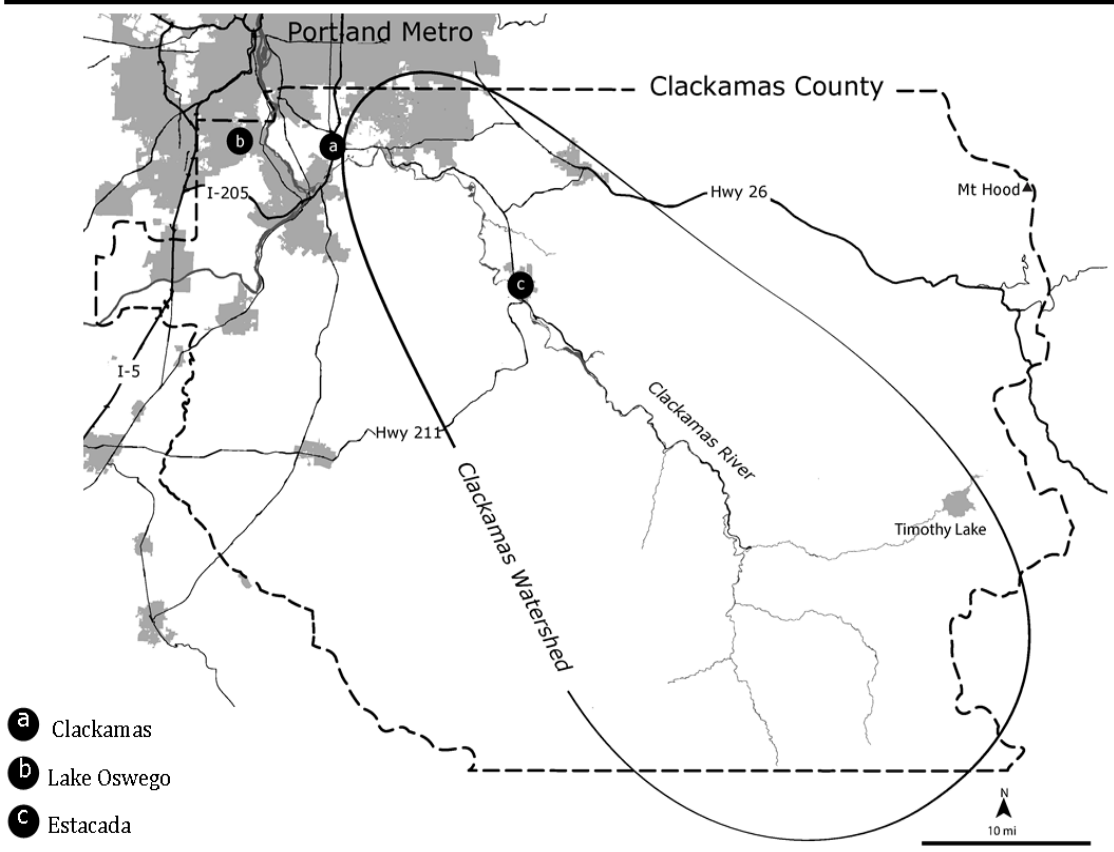

A Survey of Drinking Water Customers in Clackamas County

We need your help! The Clackamas River provides drinking water to more than a quarter million residents in the Clackamas County area. Protecting your drinking water starts at the source.

Instructions:

- Please carefully read each question and make your responses clear.

- Feel free to write in any additional comments or explanations anywhere on the questionnaire.

- Please mail your completed questionnaire back in the prepaid envelope provided.

- Your responses will be kept completely confidential.

In addition to providing drinking water the Clackamas River watershed is one of the state's most productive agriculture areas, an important recreational destination, and important habitat for some of the region's most iconic fish and wildlife.

The purpose of this study is to understand the attitudes of Clackamas River drinking water customers and their willingness to support ongoing stewardship of their drinking water watershed. The survey that follows is 8 pages in length and contains 35 questions. It should take about 20 minutes to complete.

If you have any questions or concerns, please feel free to contact us.

Dan Larson (dlar2@pdx.edu), Ph.D. Student

Max Nielsen-Pincus (maxnp@pdx.edu), Assistant Professor 


\section{Survey Questionnaire}

\begin{tabular}{|c|l|}
\hline Instructions & $\begin{array}{l}\text { Please carefully read each question and make your responses clear. } \\
-\end{array}$ \\
\hline $\begin{array}{l}\text { Your responses are completely confidential. } \\
\text { Please mail your completed questionnaire back in the prepaid envelope provided. }\end{array}$ \\
\hline $\begin{array}{c}\text { The Clackamas } \\
\text { River Watershed }\end{array}$ & Your use of the watershed and how it's important to you \\
\hline
\end{tabular}

1

Prior to receiving this survey, did you know that your tap water comes from the Clackamas River?

OYes $\bigcirc \mathrm{N}$

2

In the past year, how often did you visit natural areas in the Clackamas River Watershed for the following?

$\begin{array}{lcccccc}\begin{array}{l}\text { For each activity, select the } \\ \text { best response }\end{array} & \text { Never } & \begin{array}{c}\text { Once every } \\ \text { year }\end{array} & \begin{array}{c}\text { Once every } \\ 6 \text { Months }\end{array} & \begin{array}{c}\text { Once every } \\ 3 \text { Months }\end{array} & \begin{array}{c}\text { Once a } \\ \text { Month }\end{array} & \begin{array}{l}\text { Once a } \\ \text { Week }\end{array}\end{array}$

\begin{tabular}{lllllll} 
Work & $\bigcirc$ & $\bigcirc$ & $\bigcirc$ & $\bigcirc$ & $\bigcirc$ & $\bigcirc$ \\
Visiting property I own & $\bigcirc$ & $\bigcirc$ & $\bigcirc$ & $\bigcirc$ & $\bigcirc$ & $\bigcirc$ \\
Recreation & $\bigcirc$ & $\bigcirc$ & $\bigcirc$ & $\bigcirc$ & $\bigcirc$ & $\bigcirc$ \\
Motorized Recreation & $\bigcirc$ & 0 & 0 & 0 & $\bigcirc$ & $\bigcirc$ \\
Hunting \& gathering activities & $\bigcirc$ & $\bigcirc$ & $\bigcirc$ & $\bigcirc$ & $\bigcirc$ & $\bigcirc$ \\
Passing through & $\bigcirc$ & $\bigcirc$ & $\bigcirc$ & $\bigcirc$ & $\bigcirc$ & $\bigcirc$ \\
\hline
\end{tabular}

How much do the natural areas of the Clackamas River Watershed enhance your quality of life? (Select one)

The Clackamas River Watershed is critical to my quality of life.

The Clackamas River Watershed greatly enhances my quality of life.

The Clackamas River Watershed somewhat enhances my quality of life.

The Clackamas River Watershed slightly enhances my quality of life.

The Clackamas River Watershed does not affect my quality of life.

How much do you agree or disagree with the following statements about the Clackamas Watershed? The Clackamas River Watershed:

\begin{tabular}{|c|c|c|c|c|c|}
\hline The Clackamas Watershed & $\begin{array}{l}\text { Strongly } \\
\text { Agree }\end{array}$ & $\begin{array}{l}\text { Somewhat } \\
\text { Agree }\end{array}$ & $\begin{array}{l}\text { Neither Agree } \\
\text { nor Disagree }\end{array}$ & $\begin{array}{l}\text { Somewhat } \\
\text { Disagree }\end{array}$ & $\begin{array}{l}\text { Strongly } \\
\text { Disagree }\end{array}$ \\
\hline It is my favorite place to be & $\bigcirc$ & $\bigcirc$ & $\bigcirc$ & $\bigcirc$ & $\bigcirc$ \\
\hline $\begin{array}{l}\text { There are better places to be as far as I am } \\
\text { concerned, }\end{array}$ & $\bigcirc$ & $\bigcirc$ & $\bigcirc$ & $\bigcirc$ & 0 \\
\hline $\begin{array}{l}\text { It is the best place for me to do the outdoor } \\
\text { things I enjoy }\end{array}$ & $\bigcirc$ & $\cap$ & $\bigcirc$ & $\bigcirc$ & \\
\hline $\begin{array}{l}\text { I would enjoy the activities I do there just } \\
\text { as well in another place }\end{array}$ & O & $\cap$ & O & O & \\
\hline It reflects the type of person I am & $\bigcirc$ & 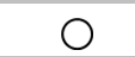 & 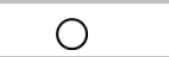 & $\bigcirc$ & \\
\hline I feel I can really be myself when I'm there & & $\frown$ & O & $\bigcirc$ & D \\
\hline I really miss it when I am away for too long & $\bigcirc$ & $\bigcirc$ & $\bigcirc$ & $\bigcirc$ & D \\
\hline I feel happiest when I am there & ○ & $\Omega$ & $\bigcirc$ & $\bigcirc$ & \\
\hline $\begin{array}{l}\text { I don't really identify with the Clackam as } \\
\text { River Watershed }\end{array}$ & $\bigcirc$ & O & $\bigcirc$ & $\bigcirc$ & $\bigcirc$ \\
\hline
\end{tabular}


The Clackamas River Watershed has many different forestry, agricultural, and residential uses before entering urban areas where drinking water is withdrawn near where the Clackamas \& Willamette Rivers meet.

5

\begin{tabular}{|c|c|c|c|c|c|c|}
\hline $\begin{array}{l}\text { For each statement, select } \\
\text { one response }\end{array}$ & $\begin{array}{l}\text { Benefits } \\
\text { greatly } \\
\text { outweigh } \\
\text { risks }\end{array}$ & $\begin{array}{l}\text { Benefits } \\
\text { slightly } \\
\text { outweigh } \\
\text { risks }\end{array}$ & $\begin{array}{l}\text { Benefits } \\
\text { and risks } \\
\text { are equal }\end{array}$ & $\begin{array}{l}\text { Risks slightly } \\
\text { outweigh } \\
\text { the benefits }\end{array}$ & $\begin{array}{l}\text { Risks greatly } \\
\text { outweigh } \\
\text { the benefits }\end{array}$ & Unsure \\
\hline $\begin{array}{l}\text { Using pesticides, herbicides, or } \\
\text { synthetic fertilizers }\end{array}$ & $\bigcirc$ & $\bigcirc$ & $\bigcirc$ & $\bigcirc$ & $\bigcirc$ & $\bigcirc$ \\
\hline $\begin{array}{l}\text { Withdrawing water from the } \\
\text { Clackamas River for irrigation }\end{array}$ & ○ & O & O & O & O & O \\
\hline Harvesting timber & $\bigcirc$ & $\bigcirc$ & $\bigcirc$ & $\bigcirc$ & $\bigcirc$ & $\bigcirc$ \\
\hline $\begin{array}{l}\text { Expanding urban areas in the } \\
\text { watershed }\end{array}$ & $\bigcirc$ & O & $\bigcirc$ & O & $\bigcirc$ & $\bigcirc$ \\
\hline $\begin{array}{l}\text { Subdividing tracts of agriculture } \\
\text { or forestry land to accommodate } \\
\text { future population growth }\end{array}$ & $\bigcirc$ & $\bigcirc$ & $\bigcirc$ & $\bigcirc$ & $\bigcirc$ & $\bigcirc$ \\
\hline $\begin{array}{l}\text { Thinning forests to reduce wildfire } \\
\text { risks }\end{array}$ & re 0 & O & O & ○ & O & O \\
\hline Generating electricity from dams & $\bigcirc$ & $\bigcirc$ & $\bigcirc$ & $\bigcirc$ & $\bigcirc$ & $\bigcirc$ \\
\hline $\begin{array}{l}\text { Withdrawing water from the } \\
\text { Clackamas for domestic uses }\end{array}$ & O & O & ○ & O & ○ & $\bigcirc$ \\
\hline
\end{tabular}

6 In general, how supportive or unsupportive are you of programs that aim to protect or enhance drinking water quality in the Clackamas River Watershed? (Select one)
O Very Supportive
Neutral
OVery Unsupportive
Somewhat Supportive
Somewhat Unsupportive

7 How urgent do you think it is to develop programs that protect or enhance drinking water quality in the Clackamas River Watershed? (Select one)
$\bigcirc$ Extremely Urgent
OSomewhat Urgent
Not Very U rgent
Very U rgent
Unsure
Not At All Urgent

8 How supportive or unsupportive would you be of establishing or enhancing the following types of education programs about watershed stewardship?

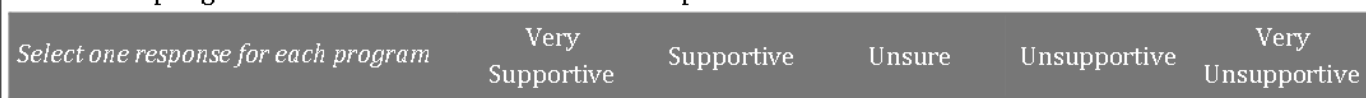

A technical assistance program to help farmers use watershed friendly practices

A pesticide stewardship program

focused on reducing pesticide use

$\bigcirc \quad \bigcirc$

A community education program about

watershed protection
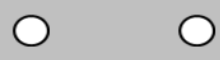

$\bigcirc$

$\bigcirc$

$\bigcirc$

A school education program on watersheds

$\bigcirc$

$\bigcirc$

$\bigcirc$

○

$\bigcirc$

$\bigcirc$ 
9 How supportive or unsupportive would you be of establishing or enhancing the following types of financial assistance programs for agricultural, forest, and residential landowners in the watershed, assuming they are well-designed and managed by a trustworthy organization?

\begin{tabular}{|c|c|c|c|c|c|}
\hline $\begin{array}{c}\text { For each program, select the one } \\
\text { best response }\end{array}$ & $\begin{array}{c}\text { Very } \\
\text { Supportive }\end{array}$ & Supportive & Unsure & Unsupportive & $\begin{array}{c}\text { Very } \\
\text { Unsupportive }\end{array}$ \\
\hline $\begin{array}{l}\text { Grant programs to help landowners do } \\
\text { watershed restoration projects }\end{array}$ & 0 & 0 & 6 & $\bigcirc$ & ) \\
\hline $\begin{array}{l}\text { Grants to residential landowners } \\
\text { to fix failing septic systems }\end{array}$ & & & & & \\
\hline $\begin{array}{l}\text { Financial rewards to landowners who } \\
\text { maintain streamside forests }\end{array}$ & & & & $\bigcirc$ & $\bigcirc$ \\
\hline $\begin{array}{l}\text { Incentive programs to help agricultural } \\
\text { or forestry landowners with the costs of } \\
\text { adopting watershed friendly practices }\end{array}$ & & & & $?$ & 0 \\
\hline
\end{tabular}

10

\begin{tabular}{|c|c|c|c|c|c|}
\hline $\begin{array}{c}\text { For each restriction, select the one } \\
\text { response }\end{array}$ & $\begin{array}{c}\text { Very } \\
\text { Supportive }\end{array}$ & Supportive & Unsure & Unsupportive & $\begin{array}{c}\text { Very } \\
\text { Unsupportive }\end{array}$ \\
\hline $\begin{array}{l}\text { Restricting the total number of new } \\
\text { residences allowed near streams and rivers }\end{array}$ & $\Omega$ & $\bigcirc$ & C & $\bigcirc$ & $\bigcirc$ \\
\hline $\begin{array}{l}\text { Restricting new residential development in } \\
\text { ecologically important areas }\end{array}$ & 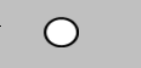 & & & & \\
\hline $\begin{array}{l}\text { Restricting new septic systems in } \\
\text { ecologically important areas }\end{array}$ & $\Omega$ & $\bigcirc$ & 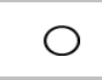 & $\bigcirc$ & $\bigcirc$ \\
\hline $\begin{array}{l}\text { Restricting the amount of pavement in new } \\
\text { residential developments }\end{array}$ & $\cap$ & 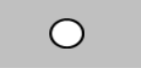 & C & $\bigcirc$ & 0 \\
\hline Restricting logging near streams & $\bigcirc$ & $\bigcirc$ & $\bigcirc$ & $\bigcirc$ & $\bigcirc$ \\
\hline $\begin{array}{l}\text { Requiring the maintenance of } \\
\text { natural vegetation near streams }\end{array}$ & $\Omega$ & 0 & O & 0 & $\bigcirc$ \\
\hline
\end{tabular}

11

\begin{tabular}{|c|c|c|c|c|c|}
\hline $\begin{array}{l}\text { For each open space protection, } \\
\text { select the one best response }\end{array}$ & $\begin{array}{c}\text { Very } \\
\text { Supportive }\end{array}$ & Supportive & Unsure & Unsupportive & $\begin{array}{c}\text { Very } \\
\text { Unsupportive }\end{array}$ \\
\hline Creating additional parks & 0 & 0 & $\bigcirc$ & 0 & 0 \\
\hline $\begin{array}{l}\text { Rewarding landowners financially for } \\
\text { limiting residential development on farm } \\
\text { and forest land }\end{array}$ & n & & ○ & C & \\
\hline $\begin{array}{l}\text { Rewarding landowners financially for } \\
\text { protecting ecologically important lands }\end{array}$ & $\Omega$ & $\cap$ & $\Omega$ & $\bigcirc$ & \\
\hline $\begin{array}{l}\text { Buying lands that are ecologically im- } \\
\text { portant for conservation }\end{array}$ & & & & & \\
\hline $\begin{array}{l}\text { Using long-term leases to conserve } \\
\text { ecologically important lands }\end{array}$ & $\bigcirc$ & $\bigcirc$ & 0 & $\bigcirc$ & 0 \\
\hline
\end{tabular}

How supportive or unsupportive would you be of the following types of open space protections, assuming they are done with willing landowners and managed by a trustworthy organization? 
12 To protect water quality, natural resource managers often recommend a natural or forested area along streams and rivers called a riparian buffer. In general, for the Clackamas River, do you think the following buffers are too small, too big, or just about right?

\begin{tabular}{|c|c|c|c|c|}
\hline $\begin{array}{c}\text { Select one response for each } \\
\text { type of buffer }\end{array}$ & Too Small & Just About Right & Too Big & Unsure \\
\hline No buffer & O & $\bigcirc$ & $\bigcirc$ & O \\
\hline 10 foot buffer & 0 & 0 & 0 & 0 \\
\hline 30 foot buffer & $\bigcirc$ & $\bigcirc$ & $\bigcirc$ & $\bigcirc$ \\
\hline 100 foot buffer & O & 0 & $\bigcirc$ & 0 \\
\hline 200 foot buffer & $\bigcirc$ & $\bigcirc$ & $\bigcirc$ & $\bigcirc$ \\
\hline 500 foot buffer & 0 & 0 & 0 & 0 \\
\hline
\end{tabular}

13 Programs and activities to maintain water quality in the Clackamas River could be implemented by a variety of agencies or organizations. How much do you trust the following types of agencies and organizations to support the health of the Clackamas River Watershed?

\begin{tabular}{|lccccc}
$\begin{array}{l}\text { For each item, please select } \\
\text { the one best response for } \\
\text { you. }\end{array}$ & $\begin{array}{c}\text { High } \\
\text { Trust }\end{array}$ & $\begin{array}{c}\text { Moderate } \\
\text { Trust }\end{array}$ & $\begin{array}{c}\text { A Little } \\
\text { Trust }\end{array}$ & $\begin{array}{c}\text { Not Much } \\
\text { Trust }\end{array}$ & Unsure \\
Federal natural resource agencies & $\bigcirc$ & $\bigcirc$ & $\bigcirc$ & $\bigcirc$ & $\bigcirc$ \\
State natural resource agencies & $\bigcirc$ & $\bigcirc$ & $\bigcirc$ & $\bigcirc$ & $\bigcirc$ \\
Local government (e.g. Metro, City) & $\bigcirc$ & $\bigcirc$ & $\bigcirc$ & $\bigcirc$ & $\bigcirc$ \\
Clackamas River Water Providers & $\bigcirc$ & $\bigcirc$ & $\bigcirc$ & $\bigcirc$ & $\bigcirc$ \\
Private landowners & $\bigcirc$ & $\bigcirc$ & $\bigcirc$ & $\bigcirc$ & $\bigcirc$ \\
Urbanites who use the watershed & $\bigcirc$ & $\bigcirc$ & $\bigcirc$ & $\bigcirc$ & $\bigcirc$ \\
Non-profit organizations & $\bigcirc$ & $\bigcirc$ & $\bigcirc$ & $\bigcirc$ & $\bigcirc$ \\
Soil \& Water Conservation Districts & $\bigcirc$ & $\bigcirc$ & $\bigcirc$ & $\bigcirc$ & $\bigcirc$ \\
\hline
\end{tabular}

Protecting

Drinking Water

\section{Investing in Source Watershed Protection}

Source Water Protection - Working with willing upstream landowners on projects to maintain and restore natural areas, wetlands, and riparian habitats. Source water protection may involve:

- Paying landowners to maintain buffers around streams

- Planting native trees and plants

- Providing assistance to landowners who adopt new practices

- Delivering education programs These efforts can help ensure water quality for downstream drinking water, and may prolong or reduce the need to make facility upgrades and purchase new technology for water treatment facilities.

How much are you willing to pay to support source water protection programs if it meant funding water quality projects on land owned by willing private property owners?

\begin{tabular}{|c|c|c|c|c|c|}
\hline Amount of support & Definitely & Probably & Unsure & Probably & Definitely \\
\hline 1 cent per month & $\bigcirc$ & 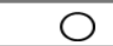 & 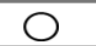 & $\bigcirc$ & O \\
\hline 50 cents per month & 0 & 0 & 0 & 0 & $\bigcirc$ \\
\hline$\$ 1$ per month & 0 & 0 & 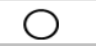 & $\bigcirc$ & ) \\
\hline$\$ 3$ per month & 0 & 0 & 0 & 0 & ) \\
\hline$\$ 5$ per month & $\bigcirc$ & $\bigcirc$ & $\bigcirc$ & $\bigcirc$ & $\bigcirc$ \\
\hline$\$ 10$ per month & O & 0 & O & $\mathrm{O}$ & O \\
\hline
\end{tabular}


15 How much are you willing to pay to support source water protection if it meant funding water quality projects on U.S. Forest Service property? For reference, the U.S. Forest Service is the biggest land manager in the Clackamas River watershed.

\begin{tabular}{|lccccc|} 
Amount of support & $\begin{array}{c}\text { Definitely } \\
\text { Yes }\end{array}$ & $\begin{array}{c}\text { Probably } \\
\text { Yes }\end{array}$ & Unsure & $\begin{array}{c}\text { Probably } \\
\text { Not }\end{array}$ & $\begin{array}{c}\text { Definitely } \\
\text { Not }\end{array}$ \\
1 cent per month & $\bigcirc$ & $\bigcirc$ & $\bigcirc$ & $\bigcirc$ & $\bigcirc$ \\
50 cents per month & $\bigcirc$ & $\bigcirc$ & $\bigcirc$ & $\bigcirc$ & $\bigcirc$ \\
\$1 per month & $\bigcirc$ & $\bigcirc$ & $\bigcirc$ & $\bigcirc$ & $\bigcirc$ \\
\$3 per month & $\bigcirc$ & $\bigcirc$ & $\bigcirc$ & $\bigcirc$ & $\bigcirc$ \\
\$5 per month & $\bigcirc$ & $\bigcirc$ & $\bigcirc$ & $\bigcirc$ & $\bigcirc$ \\
\$10 per month & $\bigcirc$ & $\bigcirc$ & $\bigcirc$ & $\bigcirc$ & $\bigcirc$ \\
\hline
\end{tabular}

16 How much are you willing to pay to support facility upgrades and new technology at your water provider's treatment plant?

\begin{tabular}{|lccccc|} 
Amount of support & $\begin{array}{c}\text { Definitely } \\
\text { Yes }\end{array}$ & $\begin{array}{c}\text { Probably } \\
\text { Yes }\end{array}$ & Unsure & $\begin{array}{c}\text { Probably } \\
\text { Not }\end{array}$ & $\begin{array}{c}\text { Definitely } \\
\text { Not }\end{array}$ \\
1 cent per month & $\bigcirc$ & $\bigcirc$ & $\bigcirc$ & $\bigcirc$ & $\bigcirc$ \\
50 cents per month & $\bigcirc$ & $\bigcirc$ & $\bigcirc$ & $\bigcirc$ & $\bigcirc$ \\
\$1 per month & $\bigcirc$ & $\bigcirc$ & $\bigcirc$ & $\bigcirc$ & $\bigcirc$ \\
\$3 per month & $\bigcirc$ & $\bigcirc$ & $\bigcirc$ & $\bigcirc$ & $\bigcirc$ \\
\$5 per month & $\bigcirc$ & $\bigcirc$ & $\bigcirc$ & $\bigcirc$ & $\bigcirc$ \\
\$10 per month & $\bigcirc$ & $\bigcirc$ & $\bigcirc$ & $\bigcirc$ & $\bigcirc$ \\
\hline
\end{tabular}

Your Use of

Water

How you use water and how you conserve it

Understanding water consumers' current uses and needs for water can help water resource managers develop strategies to avoid restrictions to water use. Please tell us about your current water use and perspectives on water conservation.

17 Do you have a yard or outdoor area that requires watering to keep vegetation alive?

$\bigcirc$ Yes $\quad$ No, if no please skip to question \#20 (next page)

18 During the summer, how often do you typically water your outdoor vegetation, including lawn? (Select one)
Every day
Once a week
$\bigcirc$ Every other day
Once or twice a month
2-3 times a week
Less than once a month (I let my outdoor areas die back)

19

When you water your yard, including your lawn, what type of water system do you typically use? (check all that apply)

$\square$ Automatic irrigation system

Manual sprinkler system or hose (shower, sink)

Drip irrigation or soaker hose
Watering can, jug or container

Recycled water from household use

Other: 


\begin{tabular}{|c|c|c|c|c|}
\hline Select one response for each statement & Agree & $\begin{array}{l}\text { Neither Agree } \\
\text { nor Disagree }\end{array}$ & Disagree & $\begin{array}{l}\text { Strongly } \\
\text { Disagree }\end{array}$ \\
\hline $\begin{array}{l}\text { I make sure to install water saving devices in my } \\
\text { house (e.g., low flow showerheads and faucets) }\end{array}$ & O & O & O & O \\
\hline $\begin{array}{l}\text { I have purchased water efficient appliances for my } \\
\text { home (e.g., dishwasher, washing machine, toilets) }\end{array}$ & C & 0 & $\bigcirc$ & $\cap$ \\
\hline I think about water conservation daily & $\bigcirc$ & O & O & O \\
\hline $\begin{array}{l}\text { Due to ongoing drought conditions, I understand } \\
\text { that my community may have to implement more } \\
\text { aggressive water conservation measures }\end{array}$ & O & O & O & O \\
\hline $\begin{array}{l}\text { If my water provider asked me to participate in a } \\
\text { water conservation program, I can see signing up }\end{array}$ & O & $\bigcirc$ & O & O \\
\hline $\begin{array}{l}\text { If I knew my neighbors were involved in a water } \\
\text { conservation program, I would be more likely to }\end{array}$ & 0 & 0 & 0 & 0 \\
\hline
\end{tabular}

21 How much do you agree or disagree with the following statements about yard and lawn maintenance?

\begin{tabular}{|c|c|c|c|c|c|}
\hline Select one response for each statement & $\begin{array}{l}\text { Strongly } \\
\text { Agree }\end{array}$ & $\begin{array}{l}\text { Somewhat } \\
\text { Agree }\end{array}$ & $\begin{array}{l}\text { Neither Agree } \\
\text { nor Disagree }\end{array}$ & $\begin{array}{l}\text { Somewhat } \\
\text { Disagree }\end{array}$ & $\begin{array}{l}\text { Strongly } \\
\text { Disagree }\end{array}$ \\
\hline $\begin{array}{l}\text { A well-maintained and well-manicured lawn } \\
\text { improves prestige and home value }\end{array}$ & $\bigcirc$ & $\bigcirc$ & $\bigcirc$ & $\bigcirc$ & $\bigcirc$ \\
\hline $\begin{array}{l}\text { The appearance of a well-maintained } \\
\text { neighborhood helps to reduce property crime }\end{array}$ & 0 & 0 & O & 0 & O \\
\hline $\begin{array}{l}\text { I feel pressure from neighbors to keep my lawn } \\
\text { and yard well maintained }\end{array}$ & $\bigcirc$ & O & $\mathrm{O}$ & O & D \\
\hline $\begin{array}{l}\text { Lawn and yard maintenance practices in my } \\
\text { neighborhood are influenced by the rules set } \\
\text { forth by my homeowner association }\end{array}$ & O & O & & 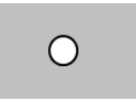 & \\
\hline $\begin{array}{l}\text { Where I live, hom eowners must have grass or } \\
\text { some form of lawn cover on their yards }\end{array}$ & O & O & $\bigcirc$ & $\Omega$ & 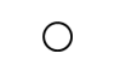 \\
\hline $\begin{array}{l}\text { The community I live in encourages homeowners } \\
\text { to plant alternatives to grass lawns, such as } \\
\text { native or other drought resistant plants }\end{array}$ & O & O & O & O & ) \\
\hline I find a brown lawn visually unappealing & O & O & O & O & O \\
\hline I have drought tolerant vegetation in my yard & O & O & O & O & O \\
\hline I use more water in the summer than winter & $\bigcirc$ & $\bigcirc$ & O & $\bigcirc$ & O \\
\hline The price of water influences how much I use & $\bigcirc$ & $\bigcirc$ & $\bigcirc$ & $\bigcirc$ & ○ \\
\hline
\end{tabular}


Climate and Water

Your views on climate and its impact on water

Climate change is the idea that the world's average temperature has been increasing over the last 150 years and may continue to increase.

22 How knowledgeable are you about climate change (Select one)

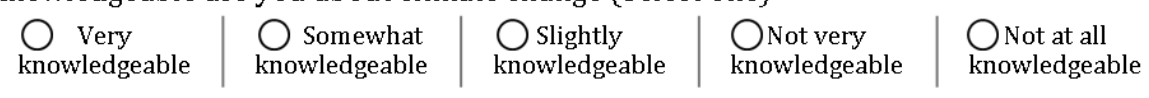

23 Please indicate the extent to which you agree or disagree with the following statements.

\begin{tabular}{|c|c|c|c|c|c|}
\hline Select one response for each statement & $\begin{array}{l}\text { Strongly } \\
\text { Agree }\end{array}$ & $\begin{array}{l}\text { Somewhat } \\
\text { Agree }\end{array}$ & $\begin{array}{l}\text { Neither Agree } \\
\text { nor Disagree }\end{array}$ & $\begin{array}{l}\text { Somewhat } \\
\text { Disagree }\end{array}$ & $\begin{array}{l}\text { Strongly } \\
\text { Disagree }\end{array}$ \\
\hline $\begin{array}{l}\text { If we do nothing, climate change will have dire } \\
\text { consequences for all life, including humans }\end{array}$ & & & & & \\
\hline $\begin{array}{l}\text { Climate might be changing but it is not as bad } \\
\text { as it is being portrayed }\end{array}$ & $\Omega$ & & & & \\
\hline $\begin{array}{l}\text { There is probably nothing we can do to stop } \\
\text { climate change because it is out of our control }\end{array}$ & 0 & 0 & 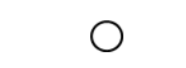 & & \\
\hline
\end{tabular}

24

How much do you agree or disagree with the following statements about the impacts of climate change on water in the Clackamas River Watershed?

$\begin{array}{cccccc}\text { Climate change will.. } & \begin{array}{c}\text { Strongly } \\ \text { Agree }\end{array} & \begin{array}{c}\text { Somewhat } \\ \text { Agree }\end{array} & \begin{array}{c}\text { Neither Agree } \\ \text { nor Disagree }\end{array} & \begin{array}{c}\text { Somewhat } \\ \text { Disagree }\end{array} & \begin{array}{c}\text { Strongly } \\ \text { Disagree }\end{array}\end{array}$

Threaten water supply due to declines in snowpack (more winter rain, less winter snow)

Threaten water supply due to increased demand (people use more water when it's hot)

Threaten drinking water quality due to an increase in extreme storms

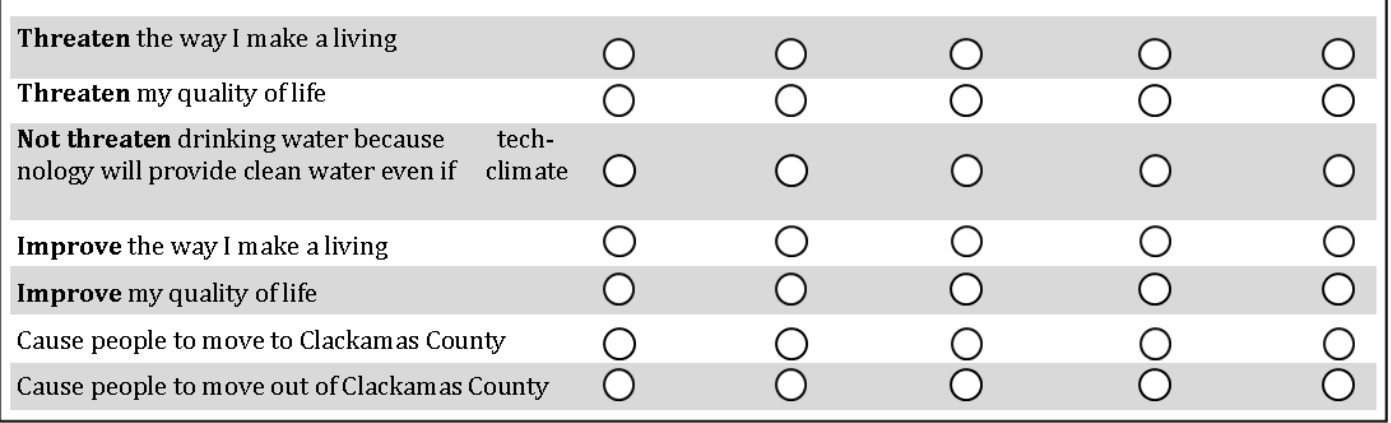

25

\begin{tabular}{|c|c|c|c|c|c|}
\hline Select one response for each statement & $\begin{array}{l}\text { Strongly } \\
\text { Agree }\end{array}$ & $\begin{array}{l}\text { Somewhat } \\
\text { Agree }\end{array}$ & $\begin{array}{l}\text { Neither Agree } \\
\text { nor Disagree }\end{array}$ & $\begin{array}{l}\text { Somewhat } \\
\text { Disagree }\end{array}$ & $\begin{array}{l}\text { Strongly } \\
\text { Disagree }\end{array}$ \\
\hline Winters are becoming warmer & O & O & O & O & \\
\hline Winters are becoming shorter & $\bigcirc$ & O & O & $\bigcirc$ & \\
\hline Summers are becoming drier & $\bigcirc$ & O & O & $\bigcirc$ & \\
\hline Summers are becoming longer & $\bigcirc$ & $\bigcirc$ & O & O & \\
\hline
\end{tabular}




\section{About}

You

Please tell us a little about yourself.

Your responses are entirely confidential

\begin{tabular}{ll|}
26 & What is your gender? $\bigcirc$ Male $\bigcirc$ Female \\
27 & What year were you born? \\
&
\end{tabular}

28 Do you consider Clackamas County to be your home? $\bigcirc$ Yes $\bigcirc$ No

29

30

31

Do you rent or own the home you live in? $\bigcirc$ Rent $\bigcirc$ own

In what year was your house built?

32

What is the size of the property you live on in acres? Or in square feet?

How many people live in your household including yourself?

Adults (18+): Children: $\square$

33 Please rate whether you consider your political attitudes to be more conservative or more liberal in nature? (Please select one)
Very conservative
Somewhat conservative
Neither conservative
nor liberal
Somewhat liberal
$\bigcirc$ Very liberal

34

Please estimate your 2014 total household income before taxes? (Please select one)
Less than $\$ 25,000$
$\bigcirc 75,000-\$ 99,999$
$\$ 150,000-\$ 174,999$
$\$ 25,000-\$ 49,999$
$\$ 100,000-\$ 124,999$
$\$ 175,000-\$ 199,999$
$\$ 50,000-\$ 74,999$
$\$ 125,000-\$ 149,999$
Greater than $\$ 200,000$

35 What is the highest level of school you have completed? (Please select one)

$\bigcirc$ Less than High School degree $\bigcirc$ Associate's degree (2 yr)

$\bigcirc$ High School degree or equivalent $\bigcirc$ Bachelor's degree (4 yr)

Some college, no degree

Graduate or professional degree

Please use the space below to write any additional comments you have about your connection to the Clackamas River watershed, or managing the watershed for the benefits it provides to our region.

Thank you for your participation in this study! If you have any questions, please contact: Dan Larson, Ph.D. Student Max Nielsen-Pincus, Assistant Professor

503-850-8209 / dlar2@pdx.edu

503-725-2827 / maxnp@pdx.edu

ש Portland State 
Survey Invitation Postcards

\section{Postcard}
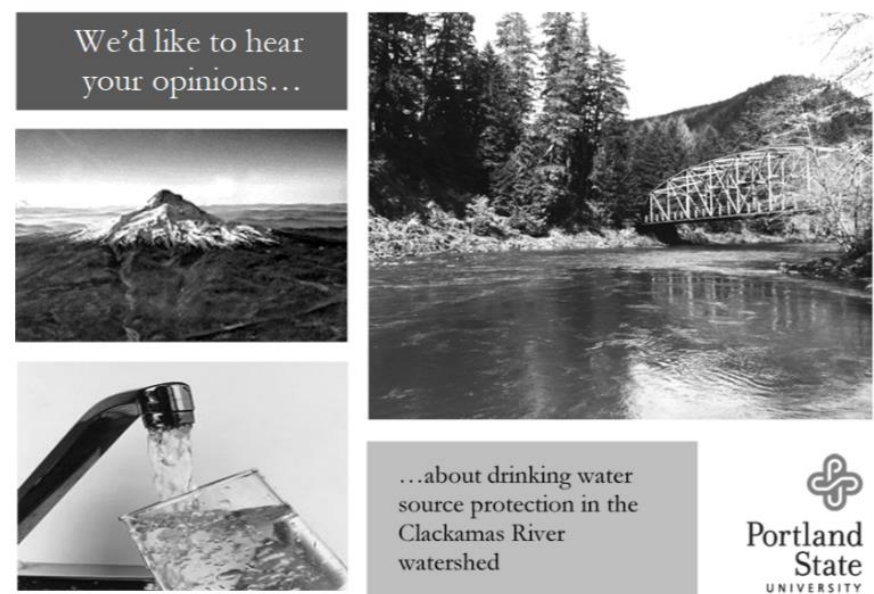

...about drinking water source protection in the Clackamas River

watershed

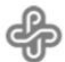

Portland State

Portland State Univers

PO Box 751 - ESM

\section{Greetings!}

We are asking for your help in a study on Clackamas County residents' opinions about protecting drinking water in the Clackamas Rives.

Within the next week, keep an eye out for a question-

naire in the mail. If you would like to avoid our mail-

ings, consider completing the questionnaire online

http://tinyullcom/ChackamasWater

Passcode

Thank you in advance for your time and support of this

study. Your input is very important to us!

Dan Larson \& Max Nielsen-Pincus

School of the Environment

Portland State University 